\title{
The new fluoroquinolones: A critical review
}

George G Zhanel PharmD PhD 1,3,5,6, Andrew Walkty BSc Pharm ${ }^{6}$, Lavern Vercaigne PharmD ${ }^{4,6}$ James A Karlowsky PhD ${ }^{1,5,6}$, John Embil MD ${ }^{2,5}$, Alfred S Gin PharmD ${ }^{4,6}$, Daryl J Hoban PhD ${ }^{1,5}$

GG Zhanel, A Walkty, L Vercaigne, et al. The new fluoroquinolones: A critical review. Can J Infect Dis 1999;10(3):207-238.

OBJECTIVE: This paper reviews the literature available on the new fluoroquinolones - clinafloxacin, gatifloxacin, grepafloxacin, levofloxacin, moxifloxacin, sparfloxacin and trovafloxacin - to compare these agents with each other and contrast them with ciprofloxacin, an older fluoroquinolone.

DATA SELECTION: Published papers used were obtained by searching MEDLINE for articles published between 1994 and 1998, inclusive. References of published papers were also obtained and reviewed. Abstracts from scientific proceedings were reviewed.

DATA EXTRACTION: Due to the limited data available on several of the agents, criteria for study inclusion in the in vitro, pharmacokinetics and in vivo sections were not restrictive.

DATA SYNTHESIS: The new fluoroquinolones offer excellent Gram-negative bacillary activity and improved Gram-positive activity (eg, against Streptococcus pneumoniae and Staphylococcus aureus) over ciprofloxacin. Clinafloxacin, gatifloxacin, moxifloxacin, sparfloxacin and trovafloxacin display improved activity against anaerobes (eg, Bacteriodes fragilis). All of the new fluoroquinolones have a longer serum half-life than ciprofloxacin (allowing for once daily dosing), and several are eliminated predominantly by nonrenal means. No clinical trials are available comparing the new fluoroquinolones with each other. Clinical trials comparing the new fluoroquinolones with standard therapy have demonstrated good efficacy in a variety of infections. Their adverse effect profile is similar to that of ciprofloxacin. Clinafloxacin and sparfloxacin cause a high incidence of phototoxicity (1.5\% to $14 \%$ and $2 \%$ to $11.7 \%$, respectively), grepafloxacin causes a high incidence of taste perversion ( $9 \%$ to $17 \%$ ) and trovafloxacin causes a high incidence of dizziness (11\%). They all interact with metal ion-containing drugs (eg, antacids), and clinafloxacin and grepafloxacin interact with theophylline. The new fluoroquinolones are expensive; however, their use may result in savings in situations where, because of their potent and broad spectrum of activity, they can be used orally in place of intravenous antibiotics.

CONCLUSIONS: The new fluoroquinolones offer advantages over ciprofloxacin in terms of improved in vitro activity and pharmacokinetics. Whether these advantages translate into improved clinical outcomes is presently unknown. The new fluoroquinolones have the potential to emerge as important therapeutic agents in the treatment of respiratory tract and genitourinary tract infections.

Key Words: Fluoroquinolones; Grepafloxacin; Levofloxacin; Moxifloxacin; Trovafloxacin

\section{Les nouvelles fluoroquinolones : une synthèse critique}

OBJECTIF : Le présent article examine la littérature disponible sur les nouvelles fluoroquinolones - clinafloxacine, gatifloxacine, grépafloxacine, lévofloxacine, moxifloxacine, sparfloxacine et trovafloxacine - pour comparer ces agents entre eux et les mettre en contraste avec la ciprofloxacine, une fluoroquinolone plus ancienne.

SÉLECTION DES DONNÉES : Les articles publiés qui ont été utilisés pour l'étude provenaient d'une recherche dans Medline des articles publiés entre 1994 et 1998, inclusivement. On a également passé en revue les références de ces articles, de même que les résumés tirés des actes des réunions scientifiques.

voir page suivante

Departments of ${ }^{1}$ Clinical Microbiology, ${ }^{2}$ Infection Control, ${ }^{3}$ Medicine and ${ }^{4}$ Pharmacy, Health Sciences Centre and ${ }^{5}$ Department of Medical Microbiology, Faculty of Medicine and ${ }^{6}$ Faculty of Pharmacy, University of Manitoba, Winnipeg, Manitoba

Correspondence and reprints: Dr GG Zhanel, Health Sciences Centre, MS673 Microbiology-820 Sherbrook Street, Winnipeg, Manitoba R3A1R9. Telephone 204-787-4902, fax 204-787-4699, e-mail ggzhanel@pcs.mb.ca 
EXTRACTION DES DONNÉES : À cause des données limitées dont on dispose sur plusieurs de ces agents, les critères d'inclusion de l'étude pour les sections in vitro, pharmacocinétique et in vivo n'étaient pas restrictifs.

SYNTHÈSE DES DONNÉES : Les nouvelles fluoroquinolones démontrent une activité excellente contre les bacilles Gram négatif et une plus grande activité contre les bacilles Gram positif (par exemple, contre Streptococcus pneumoniae et Staphylococcus aureus) que la ciprofloxacine. La clinafloxacine, la gatifloxacine, la moxifloxacine, la sparfloxacine et la trovafloxacine démontrent une plus grande activité contre les anaérobies (par exemple Bacteroides fragilis). Toutes les nouvelles fluoroquinolones ont une demi-vie plus longue dans le sérum que la ciprofloxacine (permettant une posologie uniquotidienne), et plusieurs d'entre elles sont en grande partie éliminées autrement que par la voie rénale. On ne dispose d'aucun essai clinique comparant les nouvelles fluoroquinolones entre elles. Les essais cliniques comparant les nouvelles fluoroquinolones au traitement classique ont démontré leur bonne efficacité dans une variété d'infections. Leur profil d'effets indésirables ressemble à celui de la ciprofloxacine. La clinafloxacine et la sparfloxacine causent une incidence élevée de phototoxicité (respectivement de $1,5 \%$ à $14 \%$ et de $2 \%$ à 11,7\%) ; la grépafloxacine, une incidence élevée de l'altération du goût (9\% à $17 \%$ ) et la trovafloxacine, une incidence élevée d'étourdissements (11\%). Elles interagissent toutes avec les médicaments contenant des ions métal (par exemple, les antiacides), et la clinafloxacine et la grépafloxacine interagissent avec la théophylline. Les nouvelles fluoroquinolones sont coûteuses ; cependant, leur utilisation pourrait entraîner des économies dans des situations où, à cause de leur large et puissant spectre d'activité, il est possible de les administrer oralement à la place d'antibiotiques par voie intraveineuse.

CONCLUSIONS : Les nouvelles fluoroquinolones offrent des avantages par rapport à la ciprofloxacine sur le plan de leur activité in vitro et de leur pharmacocinétique. Actuellement, on n'a pas déterminé si ces avantages se traduisent par une meilleure évolution clinique. Les nouvelles fluoroquinolones pourraient devenir d'importants agents thérapeutiques contre les infections des voies respiratoires et urinaires.

$\mathrm{T}$ he birth of the fluoroquinolones as a class of antibiotics dates back to the discovery of nalidixic acid in the early 1960s (1). Nalidixic acid demonstrated activity against Gram-negative bacilli, such as Escherichia coli, Klebsiella species and Proteus species, was well absorbed following oral administration and produced high concentrations in urine $(2,3)$. Unfortunately, there were several problems limiting its use. These included frequent daily administration (four times daily), a high tendency to select for resistant Gram-negative bacilli, poor activity against Gram-positive bacteria, photosensitivity reactions in patients and the potential to cause convulsions in patients with seizure disorders (2-5).

The introduction of norfloxacin followed by ciprofloxacin (Cipro, Bayer Healthcare Division) in the mid-1980s was a major advancement over nalidixic acid. Ciprofloxacin demonstrated excellent activity against Gram-negative bacilli and displayed some activity against Gram-positive bacteria. The pharmacokinetic profile of ciprofloxacin allowed for twice daily dosing. Ciprofloxacin's ability to achieve high concentrations in various tissues and fluids resulted in excellent clinical efficacy in a variety of infections (6). However, ciprofloxacin demonstrated limited activity against Streptococcus pneumoniae, and anaerobes at clinically achievable serum and tissue concentrations.

To improve the pharmacokinetic profile and antibacterial spectrum of ciprofloxacin, numerous modifications have been made to the fluoroquinolone structure. This paper reviews several of the antibiotics that have resulted from these modifications, namely clinafloxacin, gatifloxacin, grepafloxacin (Raxar, Glaxo Wellcome), levofloxacin (Levaquin, JanssenOrtho), moxifloxacin, sparfloxacin and trovafloxacin (Trovan, Pfizer Canada Inc). Most and possibly all of these agents will soon become available in Canada. For the purposes of this review, the term 'new fluoroquinolones' will refer only to these seven agents. This review describes in detail the chemistry, mechanism of action, mechanisms of resistance, in vitro activ- ity, pharmacokinetics, in vivo activity, adverse effects, drug interactions and pharmacoeconomic formulary considerations of the new fluoroquinolones. The objectives of this review are to summarize the information that is available on the new fluoroquinolones, to compare the various agents where possible and to point out the differences between the new fluoroquinolones and older agents in this class of antibiotics. Ciprofloxacin is included in parts of this review as a point of reference against which the new fluoroquinolones can be judged. However, for the most part, a discussion of this antibiotic is not provided in the text.

\section{CHEMISTRY}

The majority of the new fluoroquinolones are analogs of the basic quinolone molecular structure (Figure 1). However, trovafloxacin is based on a naphthyridine structure (Figure 1) (7). Important structural modifications have occurred at positions 1, 5, 7 and 8 (Figure 1), leading to the differences between the various agents. A summary of the structure activity relationships that have been documented for the fluoroquinolones is presented in Figure 2 (8). The structures of the individual fluoroquinolone molecules and the intravenous prodrug of trovafloxacin (alatrofloxacin) are presented in Figure 1 (9-15).

Substituents at position 1 of the basic quinolone structure influence the potency of antibacterial activity. A cyclopropyl substituent at this position, as is found on all of the new fluoroquinolones except levofloxacin and trovafloxacin, is considered optimal for activity $(7,8)$. The structure of levofloxacin (Figure 1) contains a third ring that links the N-1 and C-8 positions, resulting in increased activity of levofloxacin against Gram-positive bacteria, and a slight decrease in activity against Pseudomonas aeruginosa (7). Trovafloxacin (Figure 1) possesses a 2,4-difluorophenyl substituent at the N-1 position. This moiety increases potency, although not as much as a cyclopropyl group (8). The C-2 position of the basic qui- 


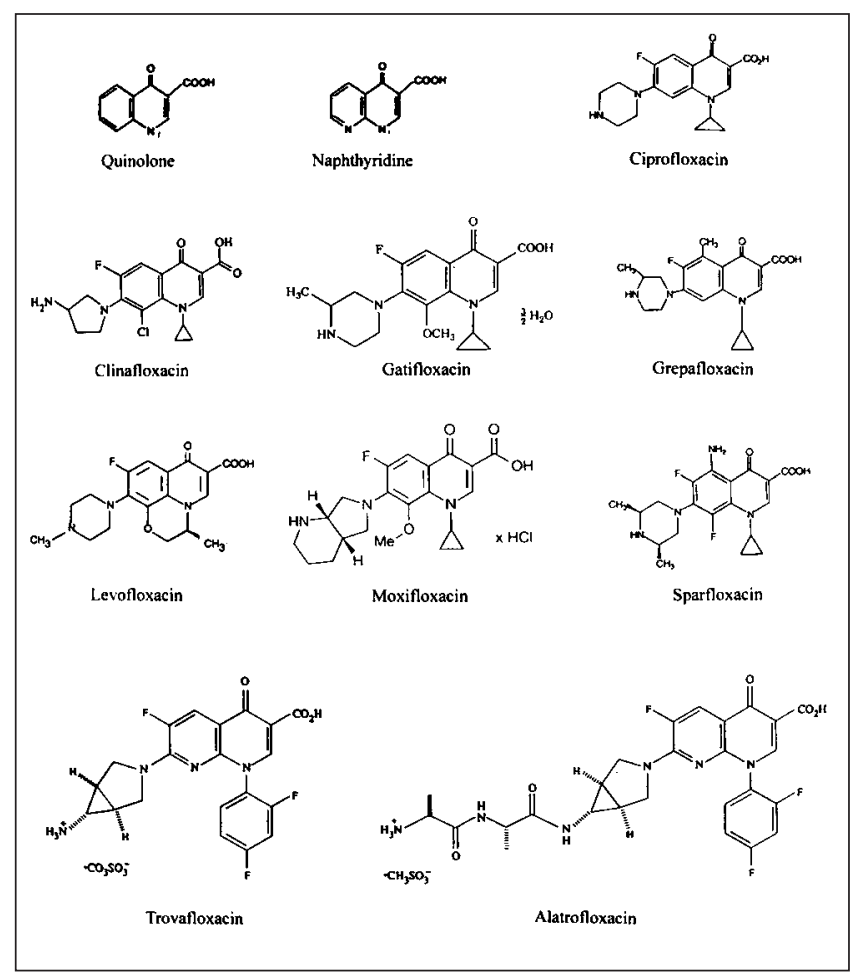

Figure 1) Chemical structures of quinolone, naphthyridine and fluoroquinolones

nolone structure is close to the DNA/DNA-gyrase binding site of the fluoroquinolones, and, thus, a hydrogen at this position is optimal (8).

All of the new fluoroquinolones possess a carboxylic acid substituent at position 3 and a carbonyl group at position 4 (Figure 1). These groups are important for binding to the DNA/DNA-gyrase complex and for transport into bacterial cells $(8,16)$. Chelate formation between these two groups and polyvalent metal ions (eg, aluminium ${ }^{+3}$, magnesium ${ }^{+2}$ ) results in drug interactions between the fluoroquinolones as a class and metal ion-containing drugs (eg, antacids, sucralfate) $(8,17-19)$.

Position 5 of the quinolone ring is important in determining in vitro potency, especially against Gram-positive bacteria, and an amino substituent (as is found on sparfloxacin) is optimal here (Figure 1) (8). Grepafloxacin contains a methyl group at $\mathrm{C}-5$ that increases in vitro potency against Gram-positive organisms to a lesser extent (8). The rest of the new fluoroquinolones lack a substituent at this position. A C-6 fluoro substituent, present in all of the new fluoroquinolones, enhances antibacterial potency and is the reason for the 'fluoro' nomenclature (Figure 1) (8).

Substituents at position 7 influence antibacterial potency, pharmacokinetics and the fluoroquinolone/theophylline interaction (Figure 1) (8). A piperazine ring at this position (eg, ciprofloxacin, gatifloxacin, grepafloxacin, levofloxacin and sparfloxacin) increases the potency of the fluoroquinolone against Gram-negative bacteria, while a pyrrolidine ring at this position (eg, clinafloxacin, moxifloxacin, trovafloxacin) improves the activity of the fluoroquinolone against Gram-

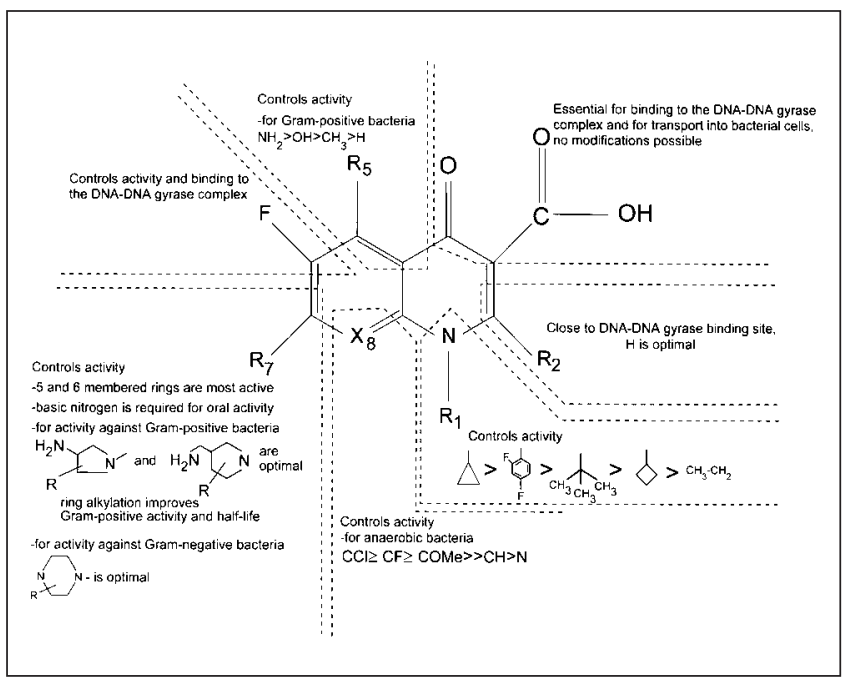

Figure 2) Structure activity relationships of the fluoroquinolones

positive bacteria (8). Alkyl substitution of either ring type (eg, gatifloxacin, grepafloxacin, levofloxacin, moxifloxacin, sparfloxacin, trovafloxacin) improves solubility (causing less risk of crystalluria), increases the activity of the fluoroquinolone against Gram-positive bacteria and prolongs the half-life of the fluoroquinolone (8). Nonbulky side chains at C-7, for example piperazine and pyrrolidine side chains without alkyl groups and nonring-side chains, have been observed to result in fluoroquinolones that interact with theophylline (8). Hence, ciprofloxacin and clinafloxacin could both theoretically be expected to interact with theophylline (8). A theophylline interaction has also been reported for grepafloxacin (12).

Position 8 plays a role in determining both activity and adverse effects. Sparfloxacin and clinafloxacin are substituted with a halogen at this position. A halogen at position $8 \mathrm{ex}-$ pands the spectrum of antibacterial activity, yielding improved activity against anaerobes. However, phototoxicity, which is a class effect of the fluoroquinolones, is greatest with a halogen at C-8 (8). A methoxy substituent at position 8, which is part of the chemical structure of both gatifloxacin and moxifloxacin (Figure 1), similarly improves activity against anaerobes. This substituent causes a low incidence of phototoxicity (8). Mizuki et al (17) have published data that demonstrated that the substituent at C-8 is important in determining whether the fluoroquinolone/theophylline interaction occurs. A nitrogen at position 8 , as is seen with trovafloxacin (Figure 1), predisposes a fluoroquinolone to such an interaction, while a halogen at this position is thought to be beneficial in preventing the interaction $(8,17)$.

\section{MECHANISM OF ACTION AND MECHANISMS OF RESISTANCE}

Mechanism of action: Fluoroquinolones must accumulate intracellularly to kill bacterial cells. In Gram-negative bacteria, this is accomplished by passive diffusion, with the porin outer membrane proteins playing a role. Fluoroquinolone uptake 
into Gram-positive bacteria, such as Bacillus subtilis, appears to involve passive diffusion (20). Once inside bacterial cells, the fluoroquinolones have two targets. The first of these targets is DNA gyrase, a type II topoisomerase composed of two A subunits (gyrA) and two B subunits (gyrB) $(20,21)$. DNA gyrase introduces negative superhelical twists into bacterial DNA and, thus, is an essential enzyme in DNA replication $(20,22)$. By inhibiting this enzyme, fluoroquinolones inhibit DNA synthesis (22). The exact binding site of fluoroquinolones within DNA gyrase is not precisely known. One proposed site is the DNA binding groove between the A and B subunits. Binding of the fluoroquinolones to this groove may conformationally change the DNA gyrase molecule. DNA itself may then become another binding site, thus resulting in the fluoroquinolones binding to both DNA and DNA gyrase (21). DNA gyrase is considered to be the primary site of fluoroquinolone action in many bacteria, including $E$ coli (23).

The second target for the fluoroquinolones is topoisomerase IV, a heterotetramer made up of two ParC subunits (parC) and two ParE subunits (parE) $(21,24)$. The protein subunits coded for by parC (ParC) and parE (ParE) are homologous to the A and B subunits of DNA gyrase, respectively (25). Topoisomerase IV carries out decatenation and relaxation of DNA, and assists with the segregation of replicating chromosomes or plasmids in bacteria (23-25). Inhibition of topoisomerase IV disrupts this process, contributing to the bactericidal activity of the fluoroquinolones. Results from studies on the development of high level resistance to fluoroquinolones in $S$ pneumoniae and Staphylococcus aureus have demonstrated that for ciprofloxacin-selected mutants, the first step involves a mutation in parc $(26,27)$. This suggests that topoisomerase IV is the primary target in these bacteria (26-28).

The primary target of fluoroquinolone action may be bacteria dependent $(23,26-28)$. Topoisomerase IV and DNA gyrase can both also act as secondary targets. Hoshino et al (23) compared data collected on the inhibition of topoisomerase IV decatenation in $E$ coli with data from other studies on the inhibition of DNA gyrase supercoiling. They found that while the fluoroquinolones were more active in $E$ coli against DNA gyrase, topoisomerase IV could act as a secondary target (23). Similarly, Gootz et al (26) found that high level resistance in $S$ pneumoniae required a mutation in gyrA following the first mutation in parc. Some of the new fluoroquinolones (clinafloxacin, sparfloxacin and trovafloxacin) remain active against $S$ pneumoniae that have a parC mutation, implying that either these compounds have a greater intrinsic potency against $S$ pneumoniae or that different fluoroquinolones selectively target one enzyme over the other $(26,29)$.

In summary, many details on the specific interactions of the various fluoroquinolones with DNA gyrase and topoisomerase IV have yet to be worked out. The primary target may depend on the type of bacteria and the specific fluoroquinolone. However, both DNA gyrase and topoisomerase IV are important targets.

Mechanisms of resistance: There are two main mechanisms of resistance to the fluoroquinolones, mutations involving the target sites (ie, DNA gyrase and topoisomerase IV) and muta- tions altering the accumulation of fluoroquinolones in bacteria. Considering target site alterations, high level resistance in ciprofloxacin-selected $S$ pneumoniae mutants results from two mutations. The first occurs in parc and the second occurs in gyrA $(26,28,29)$.

In sparfloxacin-selected $S$ pneumoniae mutants, the first mutation arises in gyrA followed by a mutation in parc (29). The order in which the two mutations occur appears to be dependent, at least in $S$ pneumoniae, on the fluoroquinolone used. In ciprofloxacin-selected $S$ aureus mutants, the first mutation identified was in parc. This was followed by either a mutation in gyrA or a mutation resulting in reduced accumulation of the fluoroquinolones (27). In contrast, a gyrA mutation (altering DNA gyrase) is necessary for moderate resistance in $E$ coli. Once this mutation has occurred, a mutation in parC (altering topoisomerase IV) followed by a second gyrA mutation is required for the development of high level resistance (30). Mutations in the gyrB gene may also play a role in the development of resistance in $E$ coli $(31,32)$. Clinically, gyrA mutations in the quinolone resistance-determining region of the gene appear to be the most important cause of resistance in $E$ coli (32).

Bacteria can also become resistant to the fluoroquinolones through reduced accumulation. One way this can happen in $E$ coli is through mutations resulting in decreased expression of the porin outer membrane protein $(\mathrm{OmpF})$, a route fluoroquinolones can enter into $E$ coli $(20,32,33)$. The second way that reduced accumulation of the fluoroquinolones can occur is through an efflux system. In $S$ aureus, efflux of fluoroquinolones is mediated by the NorA protein which is coded for by norA (27,34-36). Resistance is due to increased expression (likely through a mutation in the regulatory region) of this chromosomal gene leading to increased efflux of the fluoroquinolones (36). This resistance mechanism is less important for hydrophobic quinolones such as sparfloxacin $(27,34)$. This efflux system is not specific for fluoroquinolones, rather it is a multidrug exporter, whose likely normal physiological function is export of toxic substances (36). The existence of an efflux system in $P$ aeruginosa has also been reported (37).

The different mechanisms of resistance do not affect all of the fluoroquinolones equally $(26,29)$. In a study by Deguchi et al (38), gatifloxacin was found to possess minimum inhibitory concentrations (MICs) ranging from 0.06 to $1.0 \mu \mathrm{g} / \mathrm{mL}$ against fluoroquinolone-resistant isolates of Neisseria gonorrhoeae having mutations in both gyrA and parc. Additionally, Barry et al (39) found that pneumococci resistant to penicillin, cefotaxime (Claforan, Hoechst Marion Roussel) erythromycin, clindamycin (Dalacin C, Pharmacia \& Upjohn Inc), trimethoprim/sulfamethoxazole, tetracycline and chloramphenicol were still susceptible to clinafloxacin, sparfloxacin and trovafloxacin, suggesting that new fluoroquinolones may offer therapeutic solutions in the treatment of multidrugresistant bacteria. Advantages of the new fluoroquinolones may include treating bacteria that are resistant to some of the older fluoroquinolones such as ciprofloxacin.

For $S$ pneumoniae, the primary target is fluoroquinolone dependent. The primary target for ciprofloxacin, levofloxacin, 
TABLE 1

In vitro activity of the new fluoroquinolones and ciprofloxacin against Gram-positive aerobes

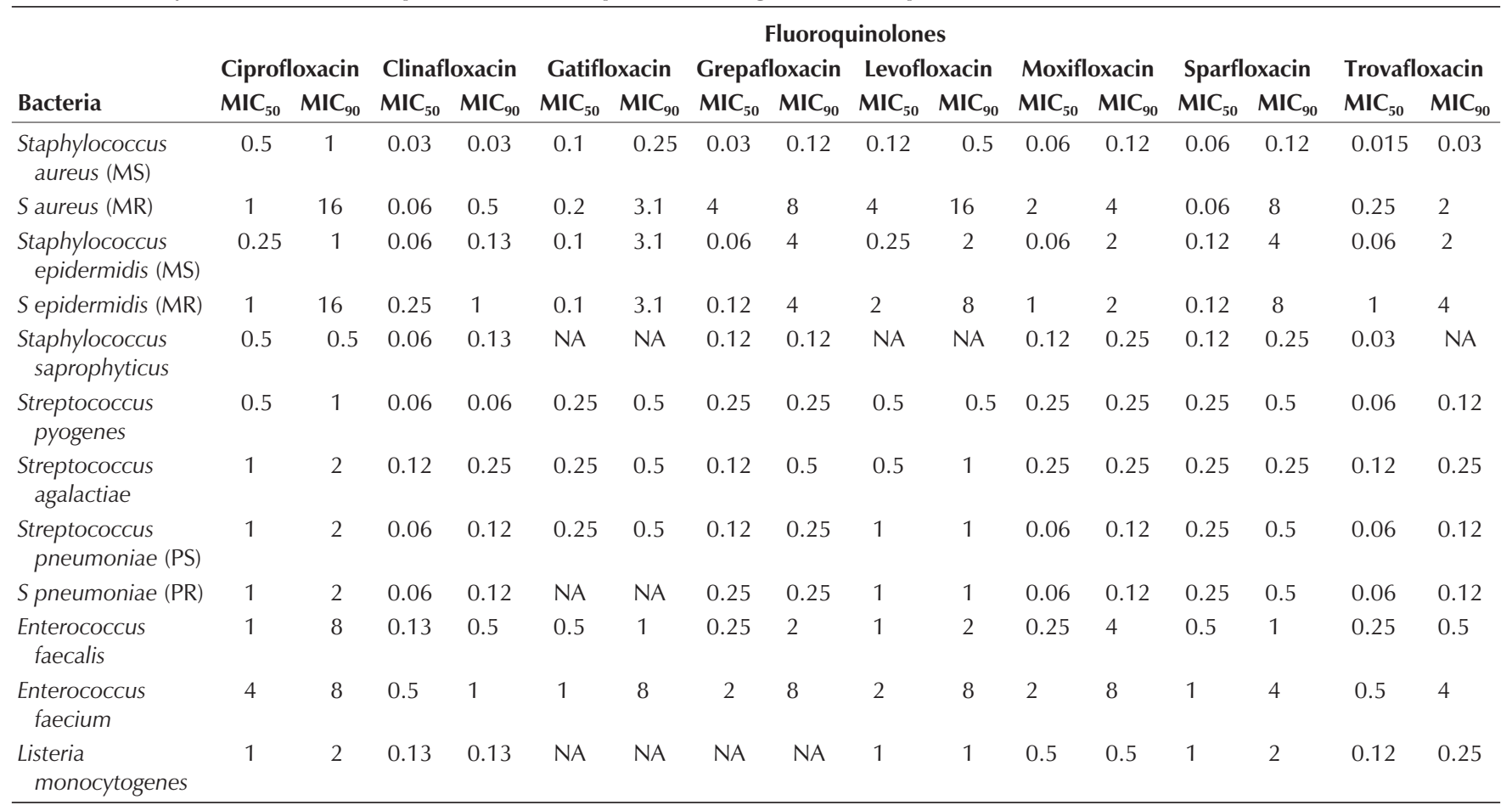

National Committee for Clinical Laboratory Standards approved and tentative breakpoints (42): S pneumoniae - grepafloxacin $\geq 2 \mu \mathrm{g} / \mathrm{mL}$ is resistant, levofloxacin $\geq 8 \mu \mathrm{g} / \mathrm{mL}$ is resistant, sparfloxacin $\geq 2 \mu \mathrm{g} / \mathrm{mL}$ is resistant, trovafloxacin $\geq 4 \mu \mathrm{g} / \mathrm{mL}$ is resistant, and no data are available for others. Staphylococcus species: ciprofloxacin $\geq 4 \mu \mathrm{g} / \mathrm{mL}$ is resistant, grepafloxacin $\geq 4 \mu \mathrm{g} / \mathrm{mL}$ is resistant, levofloxacin $\geq 8 \mu \mathrm{g} / \mathrm{mL}$ is resistant, sparfloxacin $\geq 2 \mu \mathrm{g} / \mathrm{mL}$ is resistant, and no data are available for others. MIC 50 Minimum inhibitory concentration of $50 \%$ of isolates; MIC 90 MIC of $90 \%$ of isolates; MR Methicillin resistant; MS Methicillin sensitive; NA Information not available; PR Penicillin resistant (penicillin MIC $\geq 2.0 \mu \mathrm{g} / \mathrm{mL}$ ); PS Penicillin sensitive. Adapted from references: ciprofloxacin 43-51; clinafloxacin 10,43,50,52-55; gatifloxacin 11,56-58; grepafloxacin 46,59-62; levofloxacin 43,44,48,62-67; moxifloxacin 14,43,68-71; sparfloxacin 11,14,43,44,51,54,57,58,62,65,71-75; trovafloxacin 10,43-45,47,49,53,72,76-80

moxifloxacin and trovafloxacin is ParC (40,41). ParC mutants display low level resistance (two- to eightfold increases in MIC) and are cross-resistant to all of the aforementioned agents, but not to gatifloxacin, sparfloxacin and clinafloxacin. GyrA is the primary target for gatifloxacin and sparfloxacin in $S$ pneumoniae $(40,41)$. GyrA mutants display low level resistance (two- to eightfold increases in MIC) to gatifloxacin and sparfloxacin but not to ciprofloxacin, levofloxacin, moxifloxacin, trovafloxacin and clinafloxacin $(40,41)$. It is unclear whether ParC or GyrA is the primary target for grepafloxacin because both parC and gyrA mutants result in four- to eightfold increases in MIC (41). Double mutants in parC and gyrA result in high level resistance (16- to 64-fold increases in MIC) to ciprofloxacin, gatifloxacin, grepafloxacin, levofloxacin, moxifloxacin, sparfloxacin and trovafloxacin $(40,41)$. Double mutants in parC and gyrA remain susceptible to clinafloxacin (41).

\section{IN VITRO ACTIVITY}

The in vitro activity of the new fluoroquinolones against clinically important bacterial species is summarized in Tables 1-4 (10,11,14,42-107). These tables present the concentration of antibiotic necessary to inhibit $50 \%$ of isolates (MIC50) and $90 \%$ of isolates (MIC90). The MIC values represent the midpoint of the $\mathrm{MIC}_{50}$ and $\mathrm{MIC}_{90}$ values reported in the literature examined for each drug. Inclusion criteria for papers to be used in this portion of the review were not restrictive as to growth conditions (including growth media) or the method used to carry out the study.

All of the new fluoroquinolone antibiotics display improved activity against Gram-positive bacteria relative to ciprofloxacin (Table 1) $(10,11,14,42-80)$. Based only on $\mathrm{MIC}_{90}$ values, the order of activity of the new fluoroquinolones against $S$ aureus (methicillin sensitive) is approximately clinafloxacin equal to trovafloxacin greater than grepafloxacin equal to moxifloxacin equal to sparfloxacin greater than gatifloxacin greater than levofloxacin greater than ciprofloxacin. Against $S$ pneumoniae (penicillin sensitive), the order of activity is clinafloxacin equal to moxifloxacin equal to trovafloxacin greater than grepafloxacin greater than gatifloxacin equal to sparfloxacin greater than levofloxacin greater than ciprofloxacin. A similar ranking is observed for penicillin-resistant $S$ pneumoniae. The order of activity by $\mathrm{MIC}_{90}$ values versus Enterococcus faecium is clinafloxacin greater than trovafloxacin equal to sparfloxacin greater than ciprofloxacin equal to gatifloxacin equal to grepafloxacin equal to levofloxacin equal to moxifloxacin. None of the new fluoroquinolones has an $\mathrm{MIC}_{90}$ value below $1.0 \mu \mathrm{g} / \mathrm{mL}$ against this pathogen, and the 
TABLE 2

In vitro activity of the new fluoroquinolones against Gram-negative aerobes

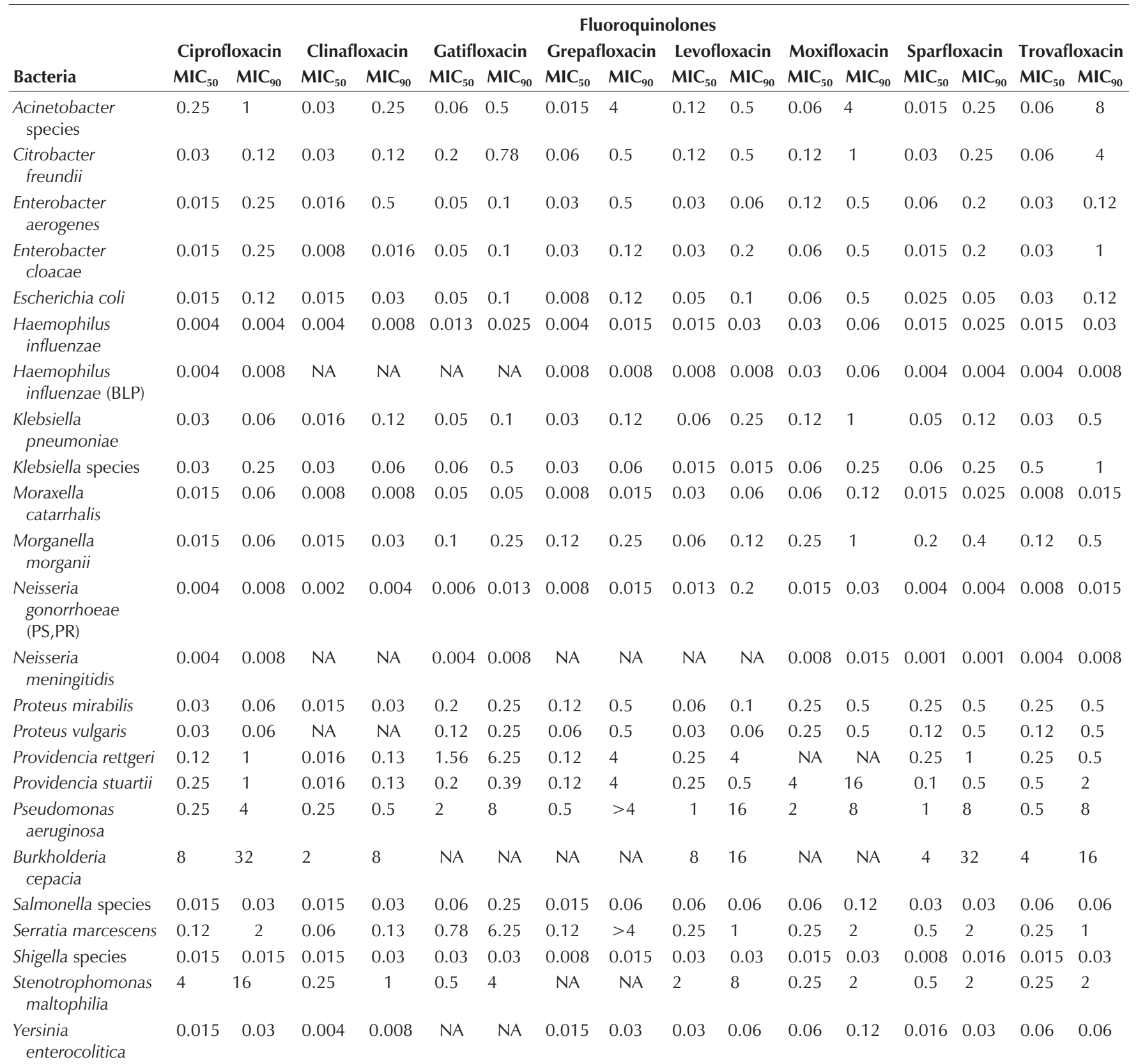

National Committee for Clinical Laboratory Standards Approved and tentative breakpoints (42): Enterobacteriaceae - ciprofloxacin $\geq 4 \mu \mathrm{g} / \mathrm{mL}$ is resistant, grepafloxacin $\geq 4 \mu \mathrm{g} / \mathrm{mL}$ is resistant, levofloxacin $\geq 8 \mu \mathrm{g} / \mathrm{mL}$ is resistant, and no data are available for others. BLP Beta-lactamase positive; $M I C_{50}$ Minimum inhibitory concentration of $50 \%$ of isolates; MIC 90 MIC of 90\% of isolates; NA Information not available; PR Penicillin resistant; PS Penicillin sensitive. Adapted from references: ciprofloxacin 43-46,59,63,80,81; clinafloxacin 10,43,50,52,54,81,82; gatifloxacin 11,56-58; grepafloxacin 46,59,61; levofloxacin 43,44,63,64,67,81,82,84; moxifloxacin 14,43,68-70; sparfloxacin 11,43,44,54,57,58,63,72-75,81; trovafloxacin 10,43-45,47,57,63,76,77,80,81

majority have an $\mathrm{MIC}_{90}$ of greater than or equal to $4.0 \mu \mathrm{g} / \mathrm{mL}$. Overall, clinafloxacin and trovafloxacin are the most active of the new fluoroquinolones versus Gram-positive bacteria. Levofloxacin displays the least improvement relative to ciprofloxacin.

Similar to ciprofloxacin, the new fluoroquinolones demonstrate excellent activity against Gram-negative bacteria (Table 2) $(10,11,14,42,43-47,50,52,54,56-59,61,63,64,67-70,72-77$, 80-84). All of the new fluoroquinolones display $\mathrm{MIC}_{90}$ values of less than $2 \mu \mathrm{g} / \mathrm{mL}$ against the majority of Gram-negative pathogens included in this review. Ranking the agents by $\mathrm{MIC}_{90}$ values, the order of activity of the new fluoroquinolones against the enterobacteriaceae is approximately clinafloxacin greater than ciprofloxacin equal to levofloxacin equal to sparfloxacin greater than gatifloxacin equal to grepafloxacin equal to trovafloxacin greater than moxifloxacin. The ranking against $P$ aeruginosa is approximately clinafloxacin greater than ciprofloxacin greater than gatifloxacin equal to moxi- 
TABLE 3

In vitro activity of the new fluoroquinolones and ciprofloxacin against anaerobes

\begin{tabular}{|c|c|c|c|c|c|c|c|c|c|c|c|c|c|c|c|c|}
\hline \multirow[b]{3}{*}{ Bacteria } & \multicolumn{16}{|c|}{ Fluoroquinolones } \\
\hline & \multicolumn{2}{|c|}{ Ciprofloxacin } & \multicolumn{2}{|c|}{ Clinafloxacin } & \multicolumn{2}{|c|}{ Gatifloxacin } & \multicolumn{2}{|c|}{ Grepafloxacin } & \multicolumn{2}{|c|}{ Levofloxacin } & \multicolumn{2}{|c|}{ Moxifloxacin } & \multicolumn{2}{|c|}{ Sparfloxacin } & \multicolumn{2}{|c|}{ Trovafloxacin } \\
\hline & $\mathrm{MIC}_{50}$ & $\mathrm{MIC}_{90}$ & $\mathrm{MIC}_{50}$ & $\mathrm{MIC}_{90}$ & $\mathrm{MIC}_{50}$ & $\mathrm{MIC}_{90}$ & $\mathrm{MIC}_{50}$ & $\mathrm{MIC}_{90}$ & $\mathrm{MIC}_{50}$ & $\mathrm{MIC}_{90}$ & $\mathrm{MIC}_{50}$ & $\mathrm{MIC}_{90}$ & $\mathrm{MIC}_{50}$ & $\mathrm{MIC}_{90}$ & $\mathrm{MIC}_{50}$ & $\mathrm{MIC}_{90}$ \\
\hline$B$ fragilis group & 8 & 32 & 0.06 & 0.25 & NA & NA & 4 & 8 & 2 & 16 & 0.25 & 1 & 2 & 4 & 0.5 & 1 \\
\hline Clostridium difficile & 8 & 16 & 0.5 & 2 & 0.78 & 1.56 & 8 & 32 & 6.25 & 6.25 & 1 & 2 & 4 & 8 & 1 & 4 \\
\hline $\begin{array}{l}\text { Clostridium } \\
\text { perfringens }\end{array}$ & 0.25 & 1 & 0.06 & 0.13 & 0.39 & 0.39 & 0.5 & 1 & 0.2 & 0.39 & 0.5 & 0.5 & 0.25 & 1 & 0.12 & 0.25 \\
\hline $\begin{array}{l}\text { Peptostreptococcus } \\
\text { species }\end{array}$ & 1 & 2 & 0.06 & 0.5 & NA & 3.13 & 1 & 2 & 0.5 & 2 & 0.12 & 0.25 & 0.25 & 0.5 & 0.06 & 0.5 \\
\hline
\end{tabular}

National Committee for Clinical Laboratory Standards approved and tentative breakpoints (85): anaerobes - trovafloxacin $\geq 8 \mu \mathrm{g} / \mathrm{mL}$ is resistant; no data are available for others. MIC 50 Minimum inhibitory concentration of 50\% of isolates; MIC 90 Minimum inhibitory concentration of 90\% of isolates; NA Information not available. Adapted from references: ciprofloxacin 10,54,86-90; clinafloxacin 10,52,54,91,92; gatifloxacin 56-58,92; grepafloxacin 59,89,92; levofloxacin 83,93,94; moxifloxacin 68-70,90,95; sparfloxacin 14,54,57,58,75,88,92,93; trovafloxacin 10,45,47,83,86,87,92

TABLE 4

In vitro activity of the new fluoroquinolones and ciprofloxacin against other clinically important bacteria

\begin{tabular}{|c|c|c|c|c|c|c|c|c|c|c|c|c|c|c|c|c|}
\hline \multirow[b]{3}{*}{ Bacteria } & \multicolumn{16}{|c|}{ Fluoroquinolones } \\
\hline & \multicolumn{2}{|c|}{ Ciprofloxacin } & \multicolumn{2}{|c|}{ Clinafloxacin } & \multicolumn{2}{|c|}{ Gatifloxacin } & \multicolumn{2}{|c|}{ Grepafloxacin } & \multicolumn{2}{|c|}{ Levofloxacin } & \multicolumn{2}{|c|}{ Moxifloxacin } & \multicolumn{2}{|c|}{ Sparfloxacin } & \multicolumn{2}{|c|}{ Trovafloxacin } \\
\hline & $\mathrm{MIC}_{50}$ & $\mathrm{MIC}_{90}$ & $\mathrm{MIC}_{50}$ & $\mathrm{MIC}_{90}$ & $\mathrm{MIC}_{50}$ & $\mathrm{MIC}_{90}$ & $\mathrm{MIC}_{50}$ & $\mathrm{MIC}_{90}$ & $\mathrm{MIC}_{50}$ & $\mathrm{MIC}_{90}$ & $\mathrm{MIC}_{50}$ & $\mathrm{MIC}_{90}$ & $\mathrm{MIC}_{50}$ & $\mathrm{MIC}_{90}$ & $\mathrm{MIC}_{50}$ & $\mathrm{MIC}_{90}$ \\
\hline $\begin{array}{l}\text { Legionella } \\
\text { pneumophila }\end{array}$ & 0.03 & 0.06 & 0.008 & 0.015 & NA & NA & 0.015 & 0.015 & 0.016 & 0.032 & 0.015 & 0.015 & 0.004 & 0.004 & 0.004 & 0.004 \\
\hline $\begin{array}{l}\text { Ureaplasma } \\
\text { urealyticum }\end{array}$ & 4 & 4 & 0.13 & 0.25 & 0.25 & 0.5 & NA & 0.5 & 0.5 & 1 & 0.12 & 0.12 & 0.25 & 0.5 & 0.13 & 0.5 \\
\hline
\end{tabular}

MIC 50 Minimum inhibitory concentration of 50\% of isolates; MIC 90 MIC of 90\% of isolates; NA Information not available. Adapted from references: ciprofloxacin 96-99; clinafloxacin 98,99; gatifloxacin 97,99; grepafloxacin 101; levofloxacin 97,99,102,103; moxifloxacin 70,104,105; sparfloxacin 96-98; trovafloxacin 96,106,107

floxacin equal to sparfloxacin equal to trovafloxacin greater than grepafloxacin greater than levofloxacin. Ciprofloxacin continues to display activity against Gram-negative bacteria that is either equivalent to or better than the activity demonstrated by the majority of the new fluoroquinolones (with the possible exception of clinafloxacin).

The activity of the new fluoroquinolones against anaerobes is presented in Table $3(10,14,45,47,52,54,56-59,68-70,75$, $83,85,86-95)$. The order of activity of the new fluoroquinolones against Bacteroides fragilis (again by $\mathrm{MIC}_{90}$ values) is approximately clinafloxacin equal to trovafloxacin greater than moxifloxacin greater than gatifloxacin equal to sparfloxacin greater than levofloxacin greater than ciprofloxacin equal to grepafloxacin. In a general sense, the anaerobic activity of new fluoroquinolones can be divided into three groups: those fluoroquinolones with greatly improved activity over ciprofloxacin (clinafloxacin, moxifloxacin, trovafloxacin); fluoroquinolones with moderately improved activity over ciprofloxacin (gatifloxacin, sparfloxacin); and fluoroquinolones with minimally improved activity over ciprofloxacin (grepafloxacin and levofloxacin).

Table 4 summarizes the activity of the new fluoroquinolones versus Chlamydia pneumoniae, Legionella pneumo- phila, Mycoplasma pneumoniae and Ureaplasma urealyticum (68,94-105). The new fluoroquinolones all have MIC90 values less than or equal to $1.0 \mu \mathrm{g} / \mathrm{mL}$ against $C$ pneumoniae, 0.032 $\mu \mathrm{g} / \mathrm{mL}$ against $L$ pneumophila, $0.5 \mu \mathrm{g} / \mathrm{mL}$ against $M$ pneumoniae and $1.0 \mu \mathrm{g} / \mathrm{mL}$ against $U$ urealyticum.

\section{PHARMACOKINETICS}

Table 5 shows the pharmacokinetic parameters of the new fluoroquinolone antibiotics following a single oral dose $(3,6$, 108-140). The kinetics of ciprofloxacin are well known, and this drug has been mostly excluded from the discussion that follows. The reader is referred to Wilson and Gruneberg (141) for a good review of the pharmacokinetics of ciprofloxacin. Each of the new fluoroquinolones is available as an oral formulation (109-111,125,142,143). Ciprofloxacin, clinafloxacin and levofloxacin are also available as intravenous formulations $(142,143)$. Trovafloxacin can be administered intravenously as the prodrug alatrofloxacin (Figure 1). Alatrofloxacin, the L-alanyl-L-alanine derivative of trovafloxacin, is rapidly converted to trovafloxacin in vivo, and is not detectable in the plasma approximately 5 mins after the infusion (135).

Absorption: All of the new fluoroquinolones for which data exist have high oral bioavailability, ranging from $72 \%$ for gre- 
TABLE 5

Pharmacokinetic parameters of the new fluoroquinolones and ciprofloxacin following a single oral dose

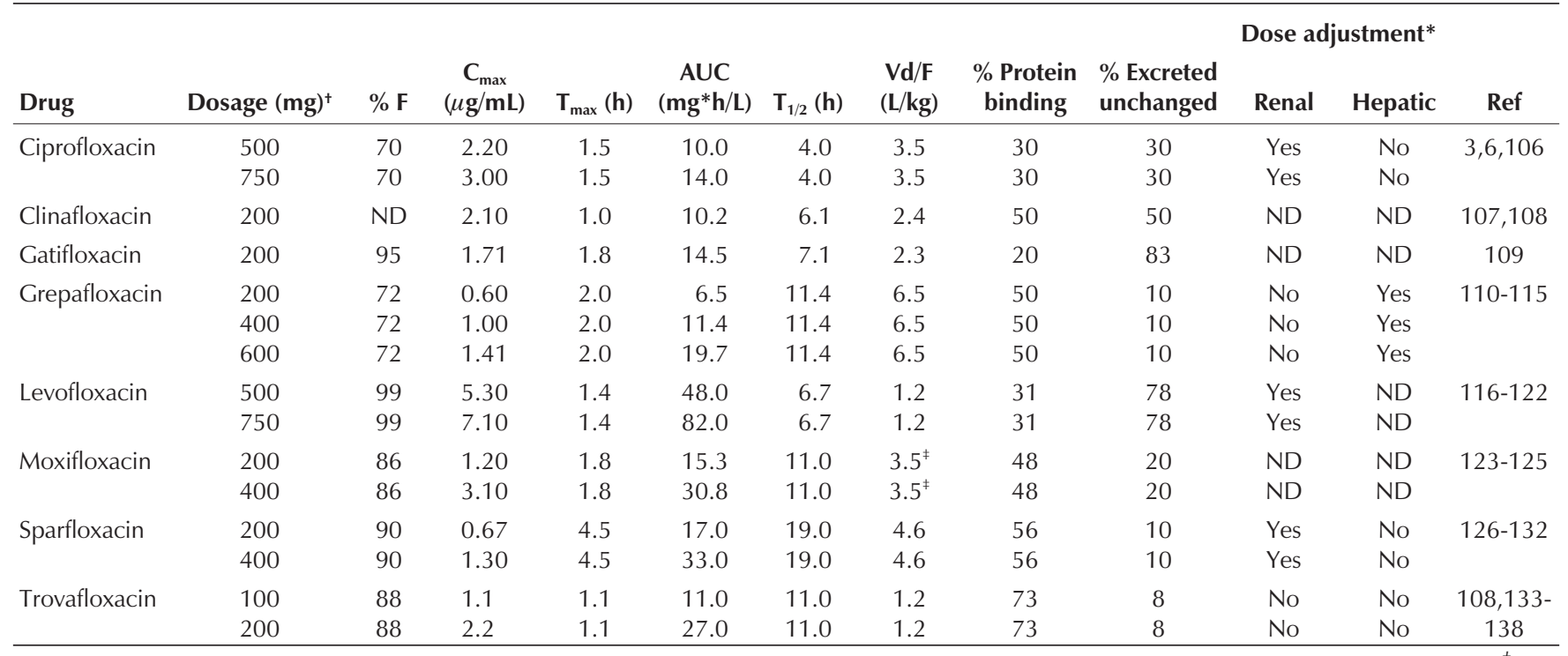

${ }^{*}$ Dose adjustment refers to whether or not the fluoroquinolone requires any dosage adjustments in patients with impaired renal or hepatic function. ${ }^{\dagger}$ Dosage only applies to peak concentration reached in the plasma/serum $\left(C_{\max }\right)$ and area under the plasma concentration time curve (AUC). The other parameters represent an average of the values available in the literature irrespective of dosage. The dosages reported are based on the dosages commonly used in clinical trials for these drugs. ${ }^{\neq}$Volume of distribution for moxifloxacin was approximated by dividing the literature value of $242 \mathrm{~L}$ by $70 \mathrm{~kg}$. F Bioavailability; ND No data; Ref References; $T_{1 / 2}$ Half-life; $T_{\max }$ Time to reach $C_{\max }$; Vd Volume of distribution

TABLE 6

Penetration of the new fluoroquinolones and ciprofloxacin into selected fluids and tissues

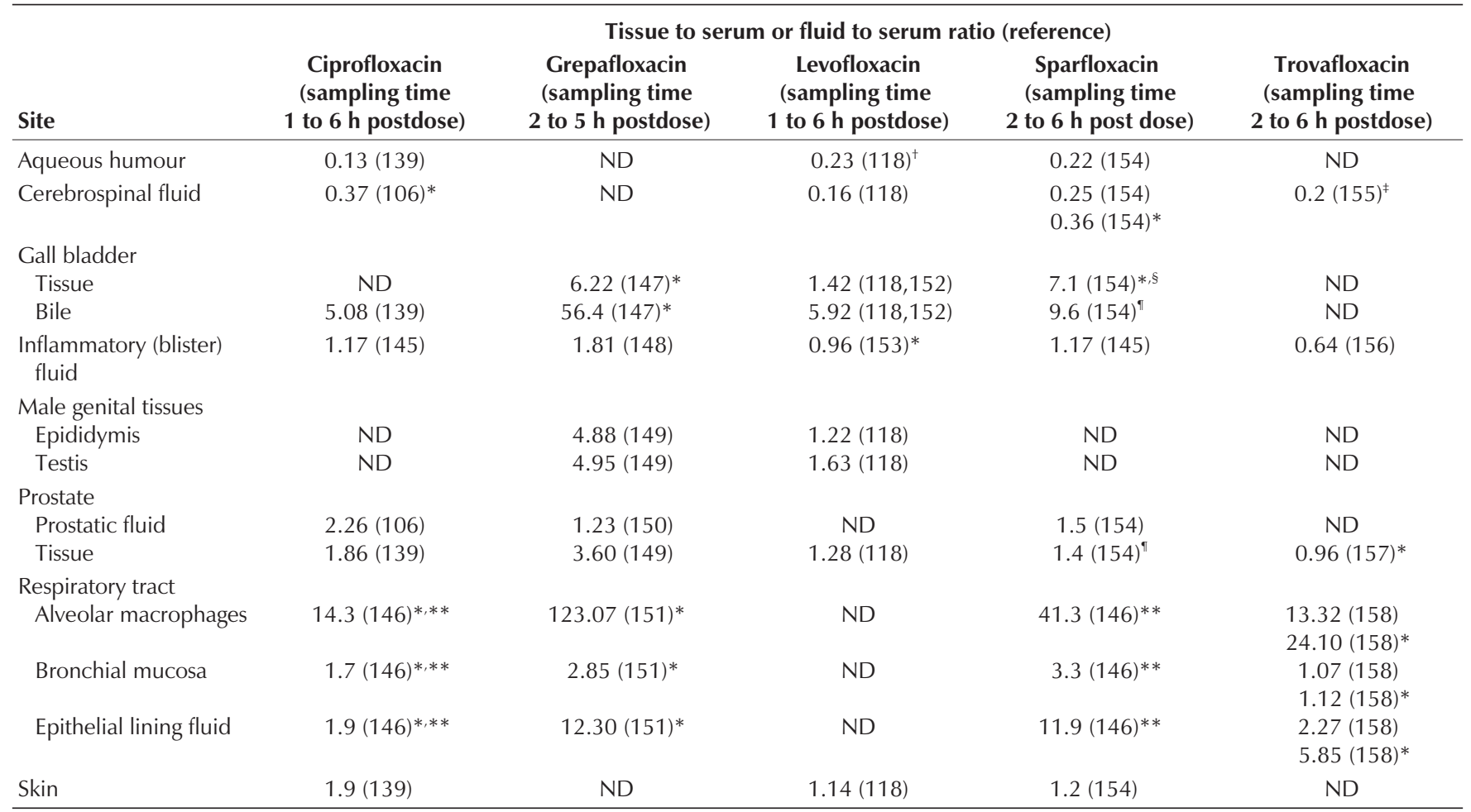

Specific dosages and sampling times for all of the above data were not provided due to lack of space - see appropriate reference for further details (found in bracks beside values). No data were available for clinafloxacin, gatifloxacin and moxifloxacin, hence they were excluded from this table. Inflammatory fluid to serum ratio was determined by taking the ratio of the area under the plasma concentration time curve values (sampling time not applicable). All others were determined by taking the ratio of tissue concentration to serum concentration (or the ratio of the mean tissue concentration to the mean serum concentration). *Multiple doses of the fluoroquinolone were administered to subjects before sample was taken. All other data were collected after a single administration of the study drug. ${ }^{+}$Sampling time of 2 to $9 \mathrm{~h}$ postdose. ${ }^{*}$ Sampling time of 1 to $24 \mathrm{~h}$ postdose. ${ }^{\S}$ Sampling time of $18 \mathrm{~h}$ postdose. ${ }^{\mathbb{T}}$ Sample taken at peak concentration reached in the plasma/serum $\left(C_{\max }\right)$ (time not specified in reference). ${ }^{*}$ Sampling time not specified. ND No data 
TABLE 7.1

Results of clinical trials involving clinafloxacin

\begin{tabular}{|c|c|c|c|c|c|c|}
\hline Author (reference) & Design & n () & Indication & Regimen & Duration & Results \\
\hline \multicolumn{7}{|c|}{ Respiratory tract infections } \\
\hline \multirow[t]{2}{*}{ Lode (161) } & \multirow{2}{*}{$\begin{array}{l}\text { Prospective, } \\
\text { randomized, } \\
\text { open }\end{array}$} & \multirow[t]{2}{*}{166 (136) } & \multirow[t]{2}{*}{$\begin{array}{l}\text { Nosocomial } \\
\text { pneumonia }\end{array}$} & $\begin{array}{l}\text { C: } 200 \text { mg every } 12 \mathrm{~h} \\
\text { (route not specified) }\end{array}$ & NA & C: 46/69 (67\%) cure* \\
\hline & & & & $\begin{array}{l}\text { Ceftaz: } 2 \mathrm{~g} \text { intravenous } \\
\quad \text { every } 8 \mathrm{~h}\end{array}$ & NA & $\begin{array}{l}\text { Ceftaz: } 43 / 67 \text { (64\%) cure* } \\
\text { (no statistical analysis was } \\
\text { provided) }\end{array}$ \\
\hline \multicolumn{7}{|c|}{ Intra-abdominal infections } \\
\hline
\end{tabular}

n 0 Number of patients (number of patients with complete data at the end of treatment or at follow-up if there was no evaluation at the end of treatment). *Cure not defined (eg, in terms of total resolution of symptoms or improvement). C Clinafloxacin; Ceftaz Ceftazidime; Duration Length of treatment; NA Information not available

pafloxacin to $99 \%$ for levofloxacin (Table 5). For the most part, these agents are absorbed relatively quickly, reaching a peak concentration in the plasma approximately 1 to $2 \mathrm{~h}$ after oral administration (Table 5). Sparfloxacin is the exception. It is absorbed slowly in comparison with the other agents, and it reaches its peak concentration in the plasma approximately $4.5 \mathrm{~h}$ after being administered (128-130). The peak plasma fluoroquinolone concentration reached is variable, depending on the dosage administered. The effect of food on the pharmacokinetics of the new fluoroquinolones has been investigated for gatifloxacin, grepafloxacin, levofloxacin, moxifloxacin, sparfloxacin and trovafloxacin $(120,127,137,144-146)$. Food has been observed to slow the absorption of some of these agents (eg, levofloxacin, moxifloxacin, trovafloxacin) and to decrease the peak plasma concentration reached. However, in all cases the changes were not deemed by the investigators to be significant, and the extent of fluoroquinolone absorption (area under the plasma concentration time curve [AUC]) was unaffected. Hence, all of the six fluoroquinolones may be administered with or without food $(120,127,137,144-146)$. Concomitant administration of intravenous morphine with oral trovafloxacin resulted in a $46 \%$ reduction in trovafloxacin peak concentration reached in the plasma/serum $\left(\mathrm{C}_{\max }\right)$ and a $36 \%$ reduction in the AUC (142).

Distribution: Similar to ciprofloxacin, the new fluoroquinolones have a high volume of distribution. This ranges from $1.2 \mathrm{~L} / \mathrm{kg}$ for levofloxacin and trovafloxacin to $6.5 \mathrm{~L} / \mathrm{kg}$ for grepafloxacin (Table 5). The new fluoroquinolones are extensively distributed into many tissues and fluids. The distribution of four of the new fluoroquinolones, grepafloxacin, levofloxacin, sparfloxacin and trovafloxacin, into selected tissues and fluids is presented in Table $6(108,120,141,147-160)$. Little data exist on the tissue and fluid distribution of the other agents. Grepafloxacin and sparfloxacin exhibit better penetration into respiratory tract tissues and fluids (eg, alveolar macrophages, bronchial mucosa and epithelial lining fluid), and inflammatory fluid than trovafloxacin, and better penetration into inflammatory fluid, gall bladder tissue and bile than levofloxacin (Table 6). This reflects the higher volume of distribution of these two agents relative to the other new fluoroquinolones (Table 5). The cerebrospinal fluid penetration of the new fluoroquinolones for which data were available (levofloxacin, sparfloxacin and trovafloxacin) is relatively low, with the fluid to serum ratio ranging from 0.16 for levofloxacin to 0.25 for sparfloxacin after administration of a single dose (Table 6). The fraction of each drug that is bound to plasma proteins is less than $80 \%$ (Table 5).

Elimination: All of the new fluoroquinolones possess a longer half-life than ciprofloxacin, with the half-life of sparfloxacin $(19 \mathrm{~h})$ being the longest (Table 5). The elimination of clinafloxacin, gatifloxacin and levofloxacin is predominantly by renal excretion (Table 5). Grepafloxacin, moxifloxacin, sparfloxacin and trovafloxacin are eliminated mainly by nonrenal means (Table 5). Grepafloxacin requires a dosage adjustment in patients with mild hepatic impairment (Child-Pugh class A) and should not be used in patients with moderate or severe hepatic impairment (Child-Pugh class B or C) (117). The dosage of levofloxacin must be adjusted in patients with renal impairment $(123,124)$. Surprisingly, the dosage of sparfloxacin must be adjusted in patients with renal impairment, even though it is eliminated for the most part nonrenally. This may be the result of enterohepatic circulation of the sparfloxacin glucuronide, a metabolite of sparfloxacin. Hydrolysis of the glucuronide back to sparfloxacin may occur due to reduced excretion of this metabolite (130). Trovafloxacin does not appear to require a dosage adjustment in patients either with renal or hepatic impairment $(139,140)$. No data exist on whether a dosage adjustment is necessary for clinafloxacin, gatifloxacin and moxifloxacin in patients with impaired renal or hepatic function.

\section{IN VIVO EFFICACY}

Clinical trials involving the new fluoroquinolones are summarized in Tables 7.1 to 7.6 (161-213). The present review includes human clinical trials, without restrictions on design, sample size, etc. These trials were obtained by searching MED- 
TABLE 7.2

Results of clinical trials involving gatifloxacin

\begin{tabular}{|c|c|c|c|c|c|c|}
\hline Author (reference) & Design & n () & Indication & Regimen & Duration & Results \\
\hline \multicolumn{7}{|c|}{ Genitourinary tract infections } \\
\hline Suzuki K et al (190) (Abst) & $\begin{array}{l}\text { Noncomparative, } \\
\text { open }\end{array}$ & $11(11)$ & $\begin{array}{c}\text { Chronic bacterial } \\
\text { prostatitis }\end{array}$ & $\begin{array}{c}\text { Gatifloxacin: } 200 \mathrm{mg} \\
\text { oral bid }\end{array}$ & 14 days & $\begin{array}{c}\text { Overall clinical efficacy*: } \\
\text { Gatifloxacin 10/11 (91\%) } \\
\text { Two to four week follow-up: } \\
\text { relapse rate } 3 / 9(33 \%)\end{array}$ \\
\hline
\end{tabular}

$n \mathrm{O}$ is the number of patients (number of patients with complete data at the end of treatment or at follow-up if there was no evaluation at the end of treatment). *Efficacy determined as 'good' or 'excellent' by the clinical investigator. Duration Length of treatment

LINE for English language trials published between the years 1995 and the first quarter of 1998, and reviewing relevant citations from all published articles. Abstracts more than two years old without subsequent publication of the data were excluded. The review primarily focuses on respiratory tract infections including chronic bronchitis and pneumonia, genitourinary tract infections, and skin and skin structure infections.

The in vivo efficacy of ciprofloxacin has been well documented elsewhere (6) and is not included in this section. No clinical trials involving moxifloxacin were identified, either in abstract form or published articles. Studies comparing the clinical efficacies of the new fluoroquinolones were not available; however, there are comparisons between several of the new fluoroquinolones and ciprofloxacin.

Respiratory tract infections - Clinafloxacin: Clinafloxacin (Table 7.1) has not been extensively evaluated in patients with respiratory tract infections. Preliminary data were obtained in an open, randomized study in which clinafloxacin was compared with ceftazidime in the treatment of nosocomial pneumonia (161). Clinafloxacin produced a cure (not defined) in $67 \%$ ( 46 of 69 ) of clinically evaluable patients and in $58 \%$ (25 of 43 ) of microbiologically evaluable patients. Ceftazidime produced cures in 64\% (43 of 67) and 56\% (24 of 43) of patients, respectively (161).

Gatifloxacin: Data are not available on the use of gatifloxacin to treat respiratory tract infections.

Grepafloxacin: Grepafloxacin has been studied in the treatment of acute bacterial exacerbations of chronic bronchitis in three trials (161-163). Chodosh et al (162) reported grepafloxacin to be equivalent to ciprofloxacin, both clinically and microbiologically. In this study, the most commonly isolated pathogens were Moraxella catarrhalis, S aureus, Haemophilus influenzae, S pneumoniae and Haemophilus parainfluenzae. These pathogens were similarly distributed among the treatment groups. Grepafloxacin produced bacteriological eradication rates, defined as eradication or presumed eradication of the original pathogen, of $96 \%$ (400 $\mathrm{mg}$ every day) and $98 \%$ (600 mg every day) versus $92 \%$ for ciprofloxacin (500 mg bid) (162). The $S$ pneumoniae eradication rates produced by both grepafloxacin regimens $(75 \%$ for the $400 \mathrm{mg}$ regimen and $88 \%$ for the $600 \mathrm{mg}$ regimen) were superior to the eradication rate reported for ciprofloxacin (40\%). However, the number of $S$ pneunomiae isolates detected in this study was very small (21 altogether), leading the authors to conclude that these results were not clinically meaningful (162). A second study, conducted by Langan et al (163), demonstrated the equiva- lence of grepafloxacin and amoxicillin in producing a successful clinical outcome. H influenzae, S pneumoniae and $M$ catarrhalis were the pathogens most frequently isolated, and these were similarly distributed among the treatment groups. At the end of treatment, grepafloxacin at daily doses of $400 \mathrm{mg}$ and $600 \mathrm{mg}$ yielded microbiological success rates (defined as eradication or presumed eradication of the original pathogen) of $97.1 \%$ and $98.2 \%$, respectively, versus $88.8 \%$ for amoxicillin. Grepafloxacin produced eradication rates against $H$ influenzae (99\% for the $400 \mathrm{mg}$ regimen and 100\% for the $600 \mathrm{mg}$ regimen) that were superior to the eradication rate produced by amoxicillin (89\%) (163). In an abstract published by Kobayashi et al (164), grepafloxacin was demonstrated to be clinically equivalent to ofloxacin. The predominant pathogens isolated in this trial were $S$ aureus, $S$ pneumoniae, $H$ influenzae and $P$ aeruginosa. Grepafloxacin produced a bacteriological eradication rate of $72.9 \%$ compared with $84.2 \%$ for ofloxacin. The authors reported that there was "no significant difference" between the two groups in terms of bacterial eradication (164).

Two prospective, randomized, double-blind, comparative studies have been published investigating the efficacy of grepafloxacin in the treatment of community-acquired pneumonia $(165,166)$. These studies found that grepafloxacin was similar to amoxicillin and clarithromycin in producing a clinical cure. In one study, grepafloxacin was found to be microbiologically superior to amoxicillin. In the grepafloxacin group, $88.2 \%$ of $H$ influenzae (15 of 17 ) and $S$ pneumoniae (15 of 17) isolates were eradicated or presumed eradicated at follow-up (28 to 42 days post-treatment) as opposed to only $66.7 \%$ of $H$ influenzae (16 of 24) and $S$ pneumoniae (eight of 12) isolates in the amoxicillin group. The $S$ pneumoniae isolates in this study included four strains that were intermediately resistant and four strains that were fully resistant to penicillin (165). The other study by Patel et al (166), published as an abstract, reported statistically equivalent bacteriological cures achieved for grepafloxacin (92\%) and clarithromycin (91\%). The predominant pathogens isolated in this study were $S$ pneumoniae, $H$ influenzae, $S$ aureus, $M$ catarrhalis and $H$ parainfluenzae (165). A third study, published in abstract form, investigated grepafloxacin in the treatment of pneumonia (167). Grepafloxacin was not statistically different from ofloxacin in terms of clinical efficacy or bacterial eradication (167). The bacteriological eradication rates were $96.4 \%$ in the grepafloxacin group and $97 \%$ in the ofloxacin group. S aureus, $S$ pneumoniae and $H$ influenzae were the main causative bacteria in this study (167). 
TABLE 7.3

Results of clinical trials involving grepafloxacin

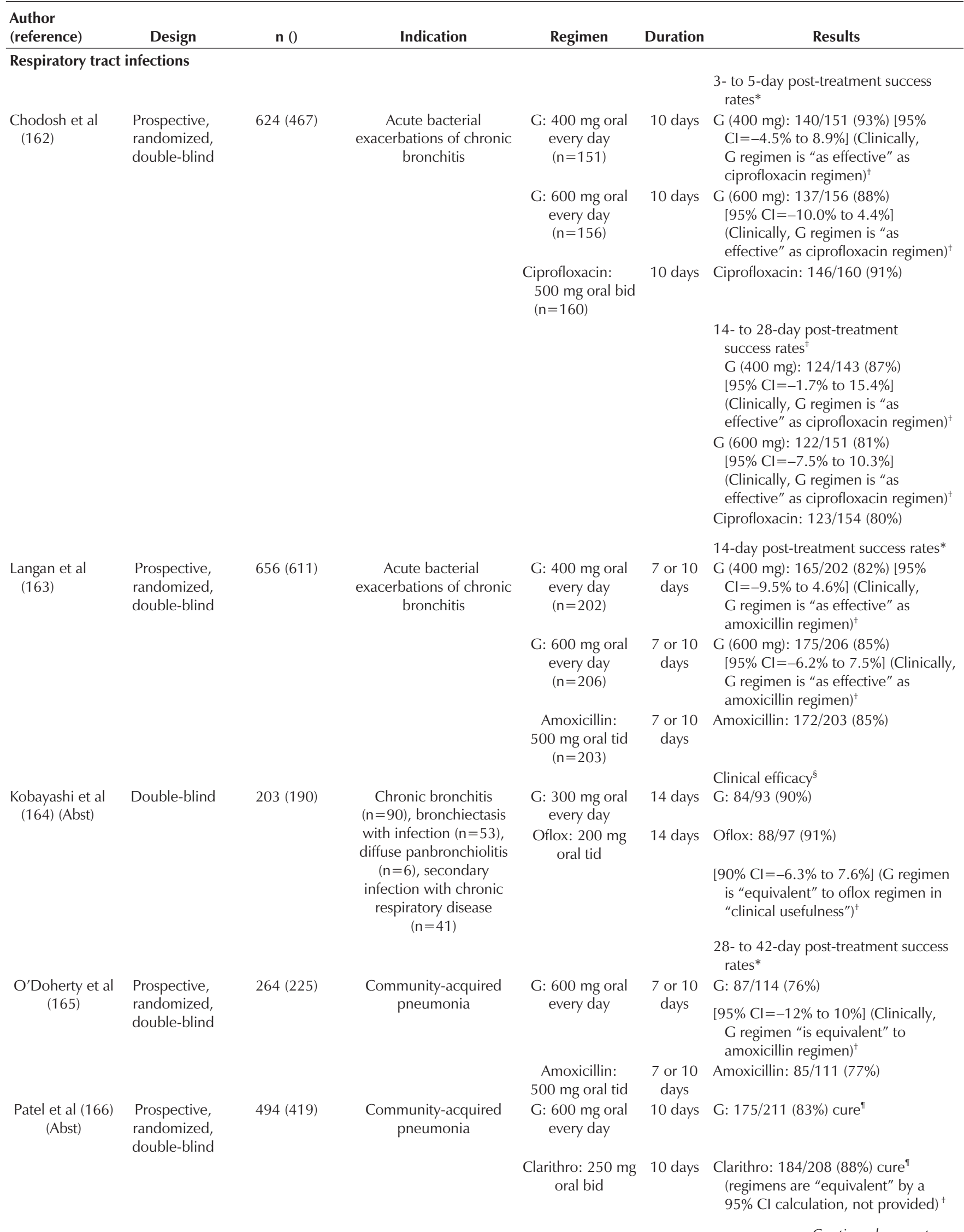


TABLE 7.3 (continued)

Results of clinical trials involving grepafloxacin

\begin{tabular}{|c|c|c|c|c|c|c|}
\hline $\begin{array}{l}\text { Author } \\
\text { (reference) }\end{array}$ & Design & n () & Indication & Regimen & Duration & Results \\
\hline & & & & & & Clinical efficacy \\
\hline \multirow[t]{2}{*}{$\begin{array}{l}\text { Kobayashi et al } \\
\text { (167) (Abst) }\end{array}$} & Double-blind & NA (225) & $\begin{array}{l}\text { Bacterial pneumonia } \\
(\mathrm{n}=195), \text { mycoplasma }\end{array}$ & $\begin{array}{l}\text { G: } 300 \text { mg oral } \\
\text { every day }\end{array}$ & 14 days & G: 108/112 (96\%) \\
\hline & & & $\begin{array}{l}\text { pneumonia }(n=27) \\
\text { chlamydia pneumonia } \\
\qquad(n=3)\end{array}$ & $\begin{array}{l}\text { Oflox: } 200 \mathrm{mg} \\
\quad \text { oral tid }\end{array}$ & 14 days & $\begin{array}{l}\text { Oflox: } 105 / 113(93 \%) \\
{[90 \% \mathrm{Cl}=-2.3 \% \text { to } 7.5 \%]} \\
(\mathrm{G} \text { regimen is "equivalent" to oflox } \\
\text { regimen in "clinical usefulness") }\end{array}$ \\
\hline \multicolumn{7}{|c|}{ Genitourinary tract infections } \\
\hline & & & & & & At 5 to 10 days post-treatment \\
\hline \multirow[t]{2}{*}{$\begin{array}{l}\text { Hook et al } \\
\text { (191) }\end{array}$} & $\begin{array}{l}\text { Randomized, } \\
\text { open }\end{array}$ & $\begin{array}{l}351(299) \\
\text { all males }\end{array}$ & $\begin{array}{l}\text { Uncomplicated } \\
\text { gonorrhea }\end{array}$ & $\begin{array}{l}\text { G: } 400 \mathrm{mg} \text { oral } \\
\text { single dose }\end{array}$ & $\begin{array}{l}\text { Single } \\
\text { dose }\end{array}$ & G: $147 / 149$ (99\%) cure** \\
\hline & & & & $\begin{array}{l}\text { Cefixime: } \\
400 \text { mg oral } \\
\text { single dose }\end{array}$ & $\begin{array}{l}\text { Single } \\
\text { dose }\end{array}$ & Cefixime: $145 / 150$ (97\%) cure** \\
\hline \multirow{2}{*}{$\begin{array}{r}\text { Matsuda et al } \\
\text { (192) (Abst) }\end{array}$} & & & $\begin{array}{l}\text { bartholinitis }(n=1) \text {, } \\
\text { Bartholin's abscess }\end{array}$ & $\begin{array}{l}\text { Oflox: } 200 \mathrm{mg} \\
\quad \text { oral tid }\end{array}$ & 7 days & Oflox: 94/101 (93\%) \\
\hline & & & $(n=54)$ & & & $\begin{array}{l}\text { [90\% } \mathrm{Cl}=-0.8 \% \text { to } 8.7 \% \text { ] (regimens } \\
\text { are "equivalent" in "clinical } \\
\text { usefulness") }\end{array}$ \\
\hline $\begin{array}{l}\text { Mroczkowski et } \\
\text { al (193) }\end{array}$ & $\begin{array}{c}\text { Open, } \\
\text { noncomparative, } \\
\text { dose ranging } \\
\text { study }\end{array}$ & $\begin{array}{l}25(21) \\
\text { all females }\end{array}$ & $\begin{array}{c}\text { Chlamydia trachomatis } \\
\text { infection }\end{array}$ & $\begin{array}{l}\text { G: } 400 \mathrm{mg} \text { oral } \\
\text { every day }\end{array}$ & 7 days & $\begin{array}{l}\text { C trachomatis culture was negative } \\
\text { at follow-up for all patients }(100 \% \\
\text { cure) (21-28 days) }\end{array}$ \\
\hline \multicolumn{7}{|c|}{ Skin and skin structure infections } \\
\hline & & & & & & Clinical efficacy ${ }^{\S}$ \\
\hline
\end{tabular}

no Number of patients (number of patients with complete data at the end of treatment or at follow-up if there was no evaluation at the end of treatment). Where $n$ appears under regimen or indication, it refers to the number of clinically evaluable patients that received the treatment or had the condition. *Success defined as cure (complete resolution of signs and symptoms of acute infection) or improvement (a reduction in the severity or number of signs and symptoms). ${ }^{\dagger}$ P not reported. ${ }^{\ddagger}$ Success defined as persistent resolution (condition is as good or better than at the end of treatment) or mild relapse (not quite as good as at the end of treatment). ${ }^{\S}$ Clinical efficacy not defined. "Clinical cure not defined. ${ }^{* *}$ Cure defined as microbiological eradication. Clarithro Clarithromycin; Duration Length of treatment; G Grepafloxacin; Oflox Ofloxacin

Levofloxacin: Three trials examining the efficacy of levofloxacin in the treatment of acute exacerbations of chronic bronchitis have been carried out (Table 7.4) (168-170). These trials have shown levofloxacin to be both equivalent to cefuroxime axetil and cefaclor, in terms of clinical and microbiological efficacy (166-168). DeAbate et al (168) reported a bacteriological eradication rate of $97.4 \%$ for levofloxacin versus $94.6 \%$ for cefuroxime axetil (Ceftin, Glaxo Wellcome). In another study, levofloxacin and cefaclor (Ceclor, Lilly) produced bacteriological eradication rates of $94 \%$ and $87 \%$, respectively (170). The most common pathogens isolated in these trials were Gramnegative aerobes and $S$ pneumoniae (168-170).

Two prospective, randomized, double-blind trials have been conducted that specifically investigated levofloxacin as a treatment for community-acquired pneumonia $(171,172)$. Levofloxacin demonstrated a clinical success rate of $96 \%$ in a trial by File et al (171) and 95\% (when taken once daily) or $94 \%$ (when taken twice daily) in a trial by Carbon et al (172). Additionally, it was found to be clinically equivalent to amoxicillin/clavulanic acid, and superior to a regimen of ceftriaxone (Rocephin, Roche) and/or cefuroxime axetil (Table 7.4). $S$ pneumoniae, $H$ influenzae, $S$ aureus and the atypical bacteria (C pneumoniae, $M$ pneumoniae, $L$ pneumophila) were the primary pathogens identified in the two studies $(171,172)$. The eradication rate (against typical pathogens) of levofloxacin $(98 \%)$ was found to be superior to the eradication rate produced by the regimen of ceftriaxone and/or cefuroxime axetil (85\%) (171). Carbon et al (172) demonstrated an equivalent eradication rate for levofloxacin $(97.8 \%$ for daily dosing or $100 \%$ for twice daily dosing) and amoxicillin/clavulanic acid (97.5\%).

Levofloxacin has also been studied in a number of noncomparative trials (published as extended abstracts) in the treatment of other respiratory tract infections, such as bronchiecta- 
TABLE 7.4

Results of clinical trials involving levofloxacin

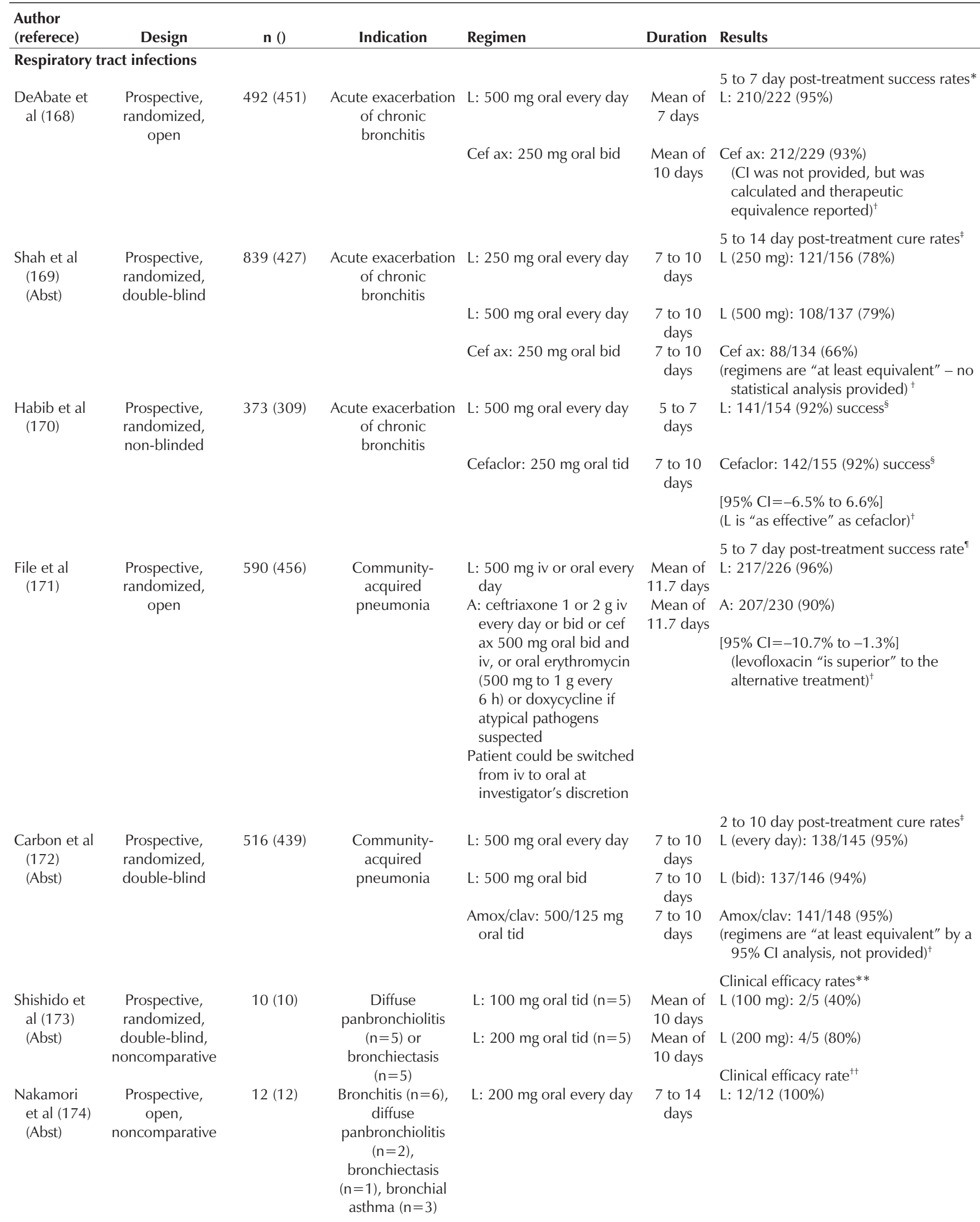


TABLE 7.4 (continued)

Results of clinical trials involving levofloxacin

\begin{tabular}{|c|c|c|c|c|c|c|}
\hline Study & Design & n () & Indication & Regimen & Duration & Results \\
\hline $\begin{array}{l}\text { Kawai (175) } \\
\text { (Abst) }\end{array}$ & $\begin{array}{c}\text { Prospective, } \\
\text { open, } \\
\text { noncomparative }\end{array}$ & $16(14)$ & $\begin{array}{l}\text { Bronchopneumonia } \\
(\mathrm{n}=12) \text {, lung abscess } \\
(\mathrm{n}=1) \text {, diffuse } \\
\text { panbronchiolitis }(\mathrm{n}=1)\end{array}$ & L: 200 mg oral tid & $\begin{array}{l}2 \text { to } 17 \\
\text { days }\end{array}$ & $\begin{array}{l}\text { Clinical efficacy rate } \text { rł }^{\ddagger \ddagger} \\
\text { L: } 14 / 14(100 \%)\end{array}$ \\
\hline $\begin{array}{l}\text { Sato et al } \\
(176) \\
\text { (Abst) }\end{array}$ & $\begin{array}{c}\text { Prospective, } \\
\text { open, } \\
\text { noncomparative }\end{array}$ & $87(51)$ & $\begin{array}{l}\text { Acute bronchitis } \\
(n=18) \text {, pneumonia } \\
(n=18) \text { or sec infect } \\
(n=15)\end{array}$ & $\begin{array}{l}\text { L: } 100 \text { mg oral tid } \\
\text { (out-patients) or } 200 \\
\text { mg oral tid } \\
\text { (in-patients) }\end{array}$ & $\begin{array}{l}3 \text { days } \\
\text { out-patients } \\
7 \text { days } \\
\text { in-patients }\end{array}$ & $\begin{array}{l}\text { Clinical efficacy at day } 3^{\ddagger \neq} \\
\text { Acute bronchitis } 15 / 18(83 \%), \\
\text { pneumonia } 16 / 18(89 \%), \\
\text { sec infect } 12 / 15(80 \%)\end{array}$ \\
\hline \multicolumn{7}{|c|}{ Genitourinary tract infections } \\
\hline $\begin{array}{l}\text { Richard et al } \\
\text { (195) }\end{array}$ & $\begin{array}{l}\text { Two randomized } \\
\text { multicentre }\end{array}$ & 259 (NA) & Acute pyelonephritis & $\begin{array}{l}\text { L: } 250 \text { mg oral every } \\
\text { day }\end{array}$ & 10 days & L: $93 \%$ success $^{\S \S}$ \\
\hline (Abst) & studies (pooled & & & Cipro: 500 mg oral bid & 10 days & Cipro: $95 \%$ success $^{\S \S}$ \\
\hline $\begin{array}{l}\text { Klimberg et } \\
\text { al (196) }\end{array}$ & $\begin{array}{l}\text { Prospective, } \\
\text { open, }\end{array}$ & $461(336)$ & $\begin{array}{l}\text { Complicated urinary } \\
\text { tract infection }\end{array}$ & $\begin{array}{l}\text { L: } 250 \mathrm{mg} \text { oral every } \\
\text { day }\end{array}$ & $\begin{array}{l}\text { Mean of } 10 \\
\text { days }\end{array}$ & $\begin{array}{l}5 \text { to } 9 \text { day post-treatment success* } \\
\text { L: } 159 / 171(93 \%)\end{array}$ \\
\hline & randomized & & & $\begin{array}{l}\text { Lome: } 400 \text { mg oral } \\
\text { every day }\end{array}$ & $\begin{array}{l}\text { Mean of } 14 \\
\text { days }\end{array}$ & $\begin{array}{l}\text { Lome: } 146 / 165(88 \%) \\
\text { Levofloxacin is "as effective" as } \\
\text { lomefloxacin ( } 95 \% \mathrm{Cl} \text { not provided)* }\end{array}$ \\
\hline $\begin{array}{l}\text { Suzuki et al } \\
\text { (197) } \\
\text { (Abst) }\end{array}$ & $\begin{array}{c}\text { Prospective, } \\
\text { open, } \\
\text { noncomparative }\end{array}$ & $28(28)$ & $\begin{array}{l}\text { Nonchlamydial } \\
\text { chronic prostatitis }\end{array}$ & $\begin{array}{l}\text { L: } 100 \mathrm{mg} \text { oral tid or } \\
200 \mathrm{mg} \text { oral bid }\end{array}$ & $\begin{array}{l}\text { Mean } 13.1 \\
\text { days }\end{array}$ & $\begin{array}{l}\text { Clinical success rate } \\
\text { L: } 21 / 28(75 \%)\end{array}$ \\
\hline \multicolumn{7}{|c|}{ Skin and skin structure infections } \\
\hline \multirow[t]{2}{*}{$\begin{array}{l}\text { Nichols et al } \\
\text { (209) }\end{array}$} & \multirow{2}{*}{$\begin{array}{l}\text { Prospective, } \\
\text { open, } \\
\text { randomized }\end{array}$} & \multirow[t]{2}{*}{$469(375)$} & \multirow{2}{*}{$\begin{array}{c}\text { Skin and skin structure } \\
\text { infections (cellulitis } \\
\text { was most common } \\
{[47 \%] \text { ) }}\end{array}$} & $\begin{array}{l}\text { L: } 500 \text { mg oral every } \\
\text { day }\end{array}$ & $\begin{array}{l}\text { Mean of } \\
9.0 \text { days }\end{array}$ & L: 178/182 (98\%) \\
\hline & & & & Cipro: 500 mg oral bid & $\begin{array}{l}\text { Mean of } \\
9.6 \text { days }\end{array}$ & $\begin{array}{l}\text { Cipro: } 182 / 193(94 \%) \\
{[95 \% \mathrm{Cl}=-7.7 \% \text { to } 0.7 \%]^{+}} \\
\text {Levofloxacin is "as effective" as } \\
\text { ciprofloxacin }\end{array}$ \\
\hline
\end{tabular}

no Number of patients (number of patients with complete data at the end of treatment or at follow-up if there was no evaluation at the end of treatment). Where $n$ appears under regimen or indication, it refers to the number of clinically evaluable patients that received the treatment or had the condition. *Success defined as cure (complete resolution of signs and symptoms) or improvement (incomplete resolution). ${ }^{\dagger}$ P not reported. ${ }^{\ddagger}$ Cure determined by clinical response. ${ }^{\S}$ Success defined as cure or improvement. "Success defined as cure (resolution of signs and symptoms associated with active infection along with improvement in chest roetgenogram findings) or improvement (incomplete resolution of signs, symptoms and chest roetgenogram findings). **Clinical efficacy was rated as "excellent" or "good". A basis for this rating (ie, evaluation of signs and symptoms) was not provided. ${ }^{++}$Clinical efficacy was rated as "excel-

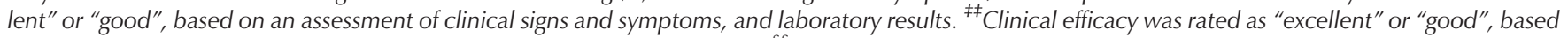
on an assessment of clinical symptoms, laboratory results and chest $x$-rays. ${ }^{\$}{ }^{A}$ A definition of clinical success was not provided. A Alternative treatment offered; Amox/clav Amoxicillin/clavulanic acid; Cef ax Cefuroxime axetil; Cipro Ciprofloxacin; Duration Length of treatment; iv Intravenous; L Levofloxacin; Lome Lomefloxacin; NA Information not available; Sec infect Secondary infection in patients with chronic respiratory disease

sis, bronchitis and bronchopneumonia. These trials involved smaller numbers of subjects than the trials reported above. Overall, levofloxacin demonstrated 'excellent' or 'good' clinical efficacy (based on clinical signs and symptoms, laboratory results and chest x-rays) in approximately $80 \%$ to $100 \%$ of the patients in these trials (173-176).
Sparfloxacin: Sparfloxacin (Table 7.5) has been extensively studied as a treatment for respiratory tract infections. Three prospective, randomized, double-blind trials have been performed where sparfloxacin was used to treat acute exacerbations of either chronic bronchitis or chronic obstructive pulmonary disease (177-179). The end of treatment clinical 
TABLE 7.5

Results of clinical trials involving sparfloxacin

\begin{tabular}{|c|c|c|c|c|c|c|}
\hline $\begin{array}{l}\text { Author } \\
\text { (reference) }\end{array}$ & Design & n () & Indication & Regimen & Duration & Results \\
\hline \multicolumn{7}{|c|}{ Respiratory tract infections } \\
\hline \multirow[t]{3}{*}{$\begin{array}{l}\text { DeAbate et al } \\
\text { (177) (Abst) }\end{array}$} & $\begin{array}{l}\text { Prospective, } \\
\text { randomized, } \\
\text { double-blind }\end{array}$ & $798(504)$ & $\begin{array}{l}\text { Acute bacterial } \\
\text { exacerbations of } \\
\text { chronic bronchitis }\end{array}$ & $\begin{array}{l}\text { S: } 400 \text { mg oral on day } \\
1 \text { then } 200 \text { mg oral } \\
\text { every day }\end{array}$ & 10 days & S: $216 / 253(85 \%)$ success* \\
\hline & & & & $\begin{array}{l}\text { Oflox: } 400 \text { mg oral } \\
\text { every } 12 \mathrm{~h}\end{array}$ & 10 days & $\begin{array}{l}\text { Oflox: } 223 / 251(89 \%) \text { success* } \\
\text { [95\% Cl }-9.3 \% \text { to } 2.4 \% \text { ] (regimens are } \\
\text { "statistically equivalent") }\end{array}$ \\
\hline & & & & & & End of treatment success ${ }^{\ddagger}$ \\
\hline \multirow[t]{5}{*}{$\begin{array}{l}\text { Allegra et al } \\
(178)\end{array}$} & $\begin{array}{l}\text { Prospective, } \\
\text { randomized, } \\
\text { double-blind }\end{array}$ & $734(351)$ & $\begin{array}{l}\text { Acute exacerbations } \\
\text { of chronic obstructive } \\
\text { pulmonary disease }\end{array}$ & $\begin{array}{l}\text { S: } 200 \text { mg oral on day } \\
1 \text { then } 100 \text { mg oral } \\
\text { every day }\end{array}$ & $\begin{array}{l}\text { Mean of } \\
10 \text { days }\end{array}$ & S: 151/173 (87\%) \\
\hline & & & & $\begin{array}{l}\text { Amox/clav: } 500 / 125 \\
\text { mg oral tid }\end{array}$ & $\begin{array}{l}\text { Mean of } \\
10 \text { days }\end{array}$ & Amox/clav: 158/178 (89\%) \\
\hline & & & & & & $\begin{array}{l}\text { [90\% } \mathrm{Cl}=-4.2 \% \text { to } 7.2 \% \text { ] (The } \\
\mathrm{S} \text { regimen is "as effective" as the } \\
\text { amox/clav regimen) }{ }^{+}\end{array}$ \\
\hline & & & & & & $\begin{array}{l}10 \text { day post-treatment success rates }{ }^{\ddagger} \\
\text { S: } 129 / 164(79 \%) \\
\text { Amox/clav: } 130 / 163(80 \%) \\
{[90 \% \mathrm{Cl}=-6.3 \% \text { to } 8.5 \%]} \\
\text { (The } \mathrm{S} \text { regimen is "as effective" as the } \\
\text { amox/clav regimen) }{ }^{\dagger}\end{array}$ \\
\hline & & & & & & Overall efficacy \\
\hline \multirow[t]{3}{*}{$\begin{array}{l}\text { Taytard et al } \\
\text { (179) (Abst) }\end{array}$} & $\begin{array}{l}\text { Prospective, } \\
\text { randomized, } \\
\text { double-blind }\end{array}$ & NA (201) & $\begin{array}{l}\text { Acute bacterial } \\
\text { exacerbations of } \\
\text { chronic bronchitis }\end{array}$ & $\begin{array}{l}\text { S: } 400 \text { mg oral on day } \\
1 \text { then } 200 \text { mg oral } \\
\text { every day }\end{array}$ & 5 days & S: $86 \%$ \\
\hline & & & & $\begin{array}{l}\text { Amox/clav: 500/125 } \\
\text { mg tid }\end{array}$ & 10 days & $\begin{array}{l}\text { Amox/clav: } 85 \% \\
\text { (a statistical analysis of these results was } \\
\text { not provided) }{ }^{\dagger}\end{array}$ \\
\hline & & & & & & End of treatment success ${ }^{\S}$ \\
\hline \multirow[t]{4}{*}{$\begin{array}{l}\text { Lode et al } \\
\qquad(180)\end{array}$} & $\begin{array}{l}\text { Prospective, } \\
\text { randomized, } \\
\text { double-blind }\end{array}$ & $808(620)$ & $\begin{array}{c}\text { Community-acquired } \\
\text { pneumonia }\end{array}$ & $\begin{array}{l}\text { S: } 400 \text { mg oral on day } \\
1 \text { then } 200 \text { mg oral } \\
\text { every day }\end{array}$ & $\begin{array}{l}\text { Mean of } \\
9.5 \text { days }\end{array}$ & S: 269/310 (87\%) \\
\hline & & & & $\begin{array}{l}\text { Amox/clav: } 500 / 125 \\
\text { mg oral tid }\end{array}$ & $\begin{array}{l}\text { Mean of } \\
9.5 \text { days }\end{array}$ & $\begin{array}{l}\text { Amox/clav: } 121 / 152(80 \%)[90 \% \\
\mathrm{Cl}=-13.4 \% \text { to }-0.9 \%] \text { (The } \mathrm{S} \\
\text { regimen is "at least as effective" as } \\
\text { the amox/clav regimen) }{ }^{+}\end{array}$ \\
\hline & & & & Erythro: $1 \mathrm{~g}$ oral bid & $\begin{array}{l}\text { Mean of } \\
9.5 \text { days }\end{array}$ & $\begin{array}{l}\text { Erythro: } 135 / 158(85 \%) \\
\text { [90\% } \mathrm{Cl}=-6.9 \% \text { to } 4.3 \%] \\
\text { (The } \mathrm{S} \text { regimen is "at least as effective" } \\
\text { as the erythro regimen) }{ }^{+}\end{array}$ \\
\hline & & & & & & 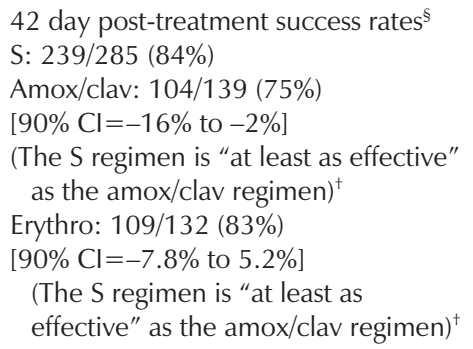 \\
\hline $\begin{array}{l}\text { Bensch et al } \\
\text { (181) (Abst) }\end{array}$ & $\begin{array}{l}\text { Prospective, } \\
\text { randomized, } \\
\text { double-blind }\end{array}$ & $428(338)$ & $\begin{array}{c}\text { Community-acquired } \\
\text { pneumonia }\end{array}$ & $\begin{array}{l}\text { S: } 400 \text { mg oral on day } \\
1 \text { then } 200 \text { mg oral } \\
\text { every day }\end{array}$ & 10 days & S: $153 / 177$ (86\%) success ${ }^{\pi}$ \\
\hline
\end{tabular}


TABLE 7.5 (continued)

Results of clinical trials involving sparfloxacin

\begin{tabular}{|c|c|c|c|c|c|c|}
\hline $\begin{array}{l}\text { Author } \\
\text { (reference) }\end{array}$ & Design & n () & Indication & Regimen & Duration & Results \\
\hline & & & & $\begin{array}{l}\text { Erythro: } 500 \mathrm{mg} \text { oral } \\
\text { every } 6 \mathrm{~h}\end{array}$ & 10 days & $\begin{array}{l}\text { Erythro: } 130 / 161(81 \%) \text { success } \\
{[95 \% \mathrm{Cl}=-2.2 \% \text { to } 13.6 \%]} \\
(\text { regimens are "statistically equivalent") }\end{array}$ \\
\hline $\begin{array}{l}\text { Donowitz et } \\
\text { al (182) } \\
\text { (Abst) }\end{array}$ & $\begin{array}{l}\text { Prospective, } \\
\text { randomized, } \\
\text { double-blind }\end{array}$ & $330(262)$ & $\begin{array}{l}\text { Community-acquired } \\
\text { pneumonia }\end{array}$ & $\begin{array}{l}\text { S: } 400 \mathrm{mg} \text { oral on day } \\
1 \text { then } 200 \mathrm{mg} \text { oral } \\
\text { every day }\end{array}$ & 10 days & S: $116 / 134$ (87\%) success" \\
\hline $\begin{array}{l}\text { Ortqvist et al } \\
\text { (183) }\end{array}$ & $\begin{array}{l}\text { Prospective, } \\
\text { randomized, } \\
\text { double-blind }\end{array}$ & $304(264)$ & $\begin{array}{c}\text { Community-acquired } \\
\text { pneumonia }\end{array}$ & $\begin{array}{l}\text { S: } 400 \text { mg oral on } \\
\text { day } 1 \text { then } 200 \\
\text { mg oral every day }\end{array}$ & $\begin{array}{l}\text { Mean of } \\
10.2 \text { days }\end{array}$ & $\begin{array}{l}\text { 4- to 7-day post-treatment success } \\
\text { S: } 124 / 131(95 \%)\end{array}$ \\
\hline \multirow[t]{4}{*}{$\begin{array}{l}\text { Portier et al } \\
\text { (184) }\end{array}$} & $\begin{array}{l}\text { Prospective, } \\
\text { randomized, } \\
\text { double-blind }\end{array}$ & $213(167)$ & $\begin{array}{l}\text { Community-acquired } \\
\text { pneumonia }\end{array}$ & $\begin{array}{l}\text { S: } 400 \text { mg oral on } \\
\text { day } 1 \text { then } 200 \\
\text { mg oral every day }\end{array}$ & $\begin{array}{l}\text { Mean of } \\
10 \text { days }\end{array}$ & S: 79/86 (92\%) \\
\hline & & & & $\begin{array}{l}\text { Amox/oflox: amox } \\
1 \mathrm{~g} \text { oral tid and }\end{array}$ & $\begin{array}{l}\text { Mean of } \\
10 \text { days }\end{array}$ & Amox/oflox: 66/81 (81\%) \\
\hline & & & & $\begin{array}{l}\text { oflox } 200 \mathrm{mg} \text { oral } \\
\text { bid }\end{array}$ & & 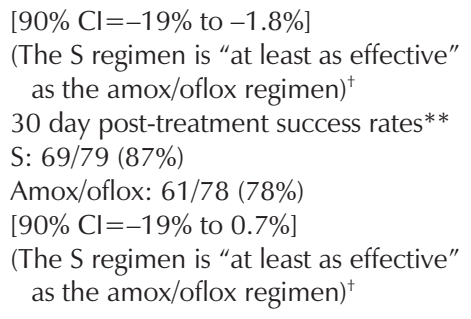 \\
\hline & & & & & & End of treatment success ${ }^{\dagger+}$ \\
\hline \multirow[t]{3}{*}{$\begin{array}{l}\text { Aubier et al } \\
(185)\end{array}$} & $\begin{array}{l}\text { Prospective, } \\
\text { randomized, } \\
\text { double-blind }\end{array}$ & $329(286)$ & $\begin{array}{c}\text { Community-acquired } \\
\text { pneumonia }\end{array}$ & $\begin{array}{l}\text { S: } 400 \text { mg oral on } \\
\text { day } 1 \text { then } 200 \\
\text { mg oral every day }\end{array}$ & $\begin{array}{l}\text { Mean of } \\
10.8 \text { days }\end{array}$ & S: 125/136 (92\%) \\
\hline & & & & $\begin{array}{l}\text { Amox: amox } 1 \mathrm{~g} \\
\text { oral tid }\end{array}$ & $\begin{array}{l}\text { Mean of } \\
10.8 \text { days }\end{array}$ & $\begin{array}{l}\text { Amox: } 131 / 150(87 \%) \\
{[90 \% \mathrm{Cl}=-10.5 \% \text { to } 1.3 \%]} \\
\text { (The } \mathrm{S} \text { regimen is at least "as effective" } \\
\text { as the amox regimen) }{ }^{+}\end{array}$ \\
\hline & & & & & & $\begin{array}{l}39 \text { to } 41 \text { day post-treatment success }{ }^{++} \\
\text {S: } 112 / 126(89 \%) \\
\text { Amox: } 118 / 140(84 \%) \\
\text { [90\% } \mathrm{Cl}=-11.4 \% \text { to } 2.2 \%] \\
\text { (The } \mathrm{S} \text { regimen is at least "as effective" }_{\text {as the amox regimen })^{+}}\end{array}$ \\
\hline \multicolumn{7}{|c|}{ Genitourinary tract infections } \\
\hline & & & & & & $\begin{array}{l}\text { Less than } 15 \text { day post-treatment } \\
\text { success }^{\ddagger \ddagger}\end{array}$ \\
\hline \multirow[t]{2}{*}{$\begin{array}{l}\text { Moi et al } \\
\text { (198) }\end{array}$} & $\begin{array}{l}\text { Prospective, } \\
\text { randomized, } \\
\text { double-blind }\end{array}$ & $\begin{array}{l}238(184) \\
\text { all males }\end{array}$ & $\begin{array}{l}\text { Acute gonococcal } \\
\text { urethritis }\end{array}$ & $\begin{array}{l}\text { S: } 200 \mathrm{mg} \text { oral } \\
\text { single dose }\end{array}$ & Single dose & S: 95/96 (99\%) \\
\hline & & & & $\begin{array}{l}\text { Cipro: } 250 \mathrm{mg} \text { oral } \\
\text { single dose }\end{array}$ & Single dose & $\begin{array}{l}\text { Cipro: } 86 / 88(98 \%) \\
{[90 \% \mathrm{Cl}=-4.4 \% \text { to } 1.9 \%]} \\
(\text { regimens are "equally effective") })^{+}\end{array}$ \\
\hline
\end{tabular}


TABLE 7.5 (continued)

Results of clinical trials involving sparfloxacin

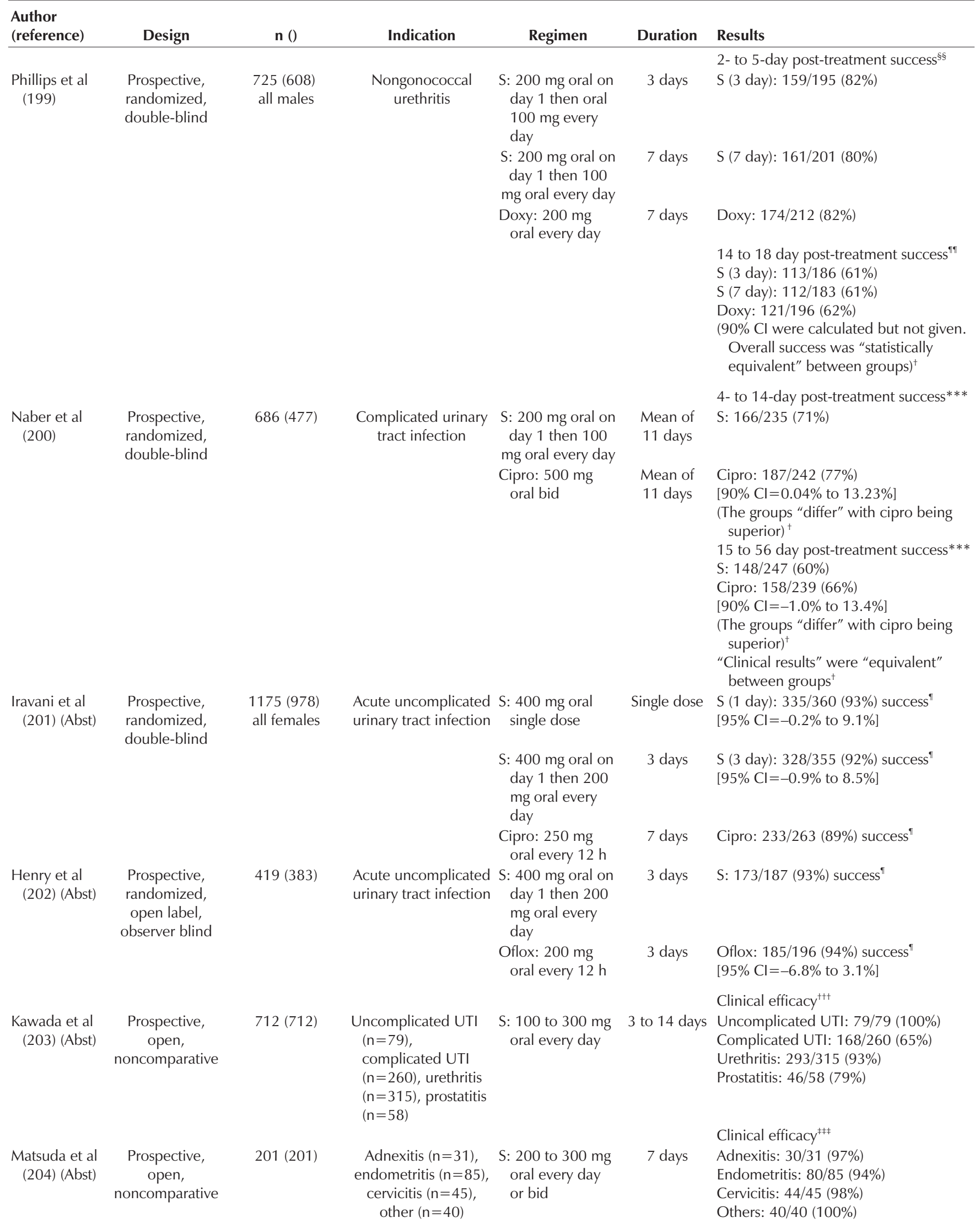


TABLE 7.5 (continued)

Results of clinical trials involving sparfloxacin

\begin{tabular}{|c|c|c|c|c|c|c|}
\hline $\begin{array}{l}\text { Author } \\
\text { (reference) }\end{array}$ & Design & n () & Indication & Regimen & Duration & Results \\
\hline \multicolumn{7}{|c|}{ Skin and skin structure infections } \\
\hline $\begin{array}{l}\text { Lipsky et al } \\
\text { (210) (Abst) }\end{array}$ & $\begin{array}{l}\text { Prospective, } \\
\text { randomized, } \\
\text { double-blind }\end{array}$ & $603(475)$ & $\begin{array}{c}\text { Skin and skin } \\
\text { structure infections }\end{array}$ & $\begin{array}{l}\text { S: } 400 \text { mg oral on } \\
\text { day } 1 \text { then } 200 \\
\text { mg oral every } \\
\text { day }\end{array}$ & 10 days & $\begin{array}{l}\text { Clinical success }{ }^{\ddagger} \\
\text { S: } 90 \%\end{array}$ \\
\hline $\begin{array}{l}\text { Takahashi et } \\
\text { al (211) } \\
\text { (Abst) }\end{array}$ & $\begin{array}{c}\text { Prospective, } \\
\text { open, } \\
\text { noncomparative }\end{array}$ & 179 (179) & $\begin{array}{l}\text { Various (folliculitis, } \\
\text { furuncle, impetigo, } \\
\text { erysipelas, } \\
\text { subcutaneous abscess } \\
\text { plus many others) }\end{array}$ & $\begin{array}{l}\text { S: } 100 \text { or } 200 \text { mg } \\
\text { oral every day } \\
\text { or bid }\end{array}$ & 7 or 10 days & $\begin{array}{l}\text { Clinical efficacy } \\
\text { S: } 155 / 179(87 \%)\end{array}$ \\
\hline
\end{tabular}

no Number of patients (number of patients with complete data at the end of treatment or at follow-up if there was no evaluation at the end of treatment). Where $n$ appears under regimen or indication, it refers to the number of clinically evaluable patients that received the treatment or had the condition. *Success defined as cure or improvement with eradication or presumed eradication. ${ }^{\dagger}$ P not reported. ${ }^{*}$ Success defined as cure (return to normal of evaluated symptoms) or improvement (decrease in evaluated symptoms); ${ }^{\S}$ Success defined as cure (complete resolution of signs and symptoms) and resolution or improvement on chest radiography or clinical improvement (incomplete resolution) and resolution on chest radiography. "Success defined by clinical response. **Success defined as clinical cure (apyrexia plus resolution of all signs and symptoms) and resolution or improvement of radiographic signs, or as clinical improvement (apyrexia plus improvement of signs and symptoms) with resolution or improvement of radiographic signs. ${ }^{+t}$ Success defined as radiographic resolution or improvement and clinical cure (absence of baseline symptoms), or radiographic resolution and clinical improvement (absence of chills and fever). ${ }^{\neq}$Success defined as eradication of Neisseria gonorrhoeae, clinical cure or improvement (disappearance or improvement of symptoms) and less than 10 polymorphonuclear neutrophils (PMNs) per field (magnification $\times 1000) .{ }^{\S}$ Success defined as clinical cure or clinical improvement less than or equal to 5 PMNs (magnification $\times 1000$ ), plus the abscence of Chlamydia trachomatis. "Success defined as clinical cure less than or equal to 10 PMNs (must be fewer than at end of treatment visit) and abscence of $\mathrm{C}$ trachomatis. ${ }^{* *}$ Success defined as overall efficacy based on clinical efficacy (resolution of symptoms present at inclusion into study) and bacteriological efficacy (eradication of initial pathogen). ${ }^{+t+}$ Clinical efficacy evaluated based on changes in symptoms. ${ }_{\neq \neq \neq}$Clinical efficacy was rated as "excellent" or "good", based on findings before and after treatment. ${ }^{\S \S}$ Clinical efficacy was rated as "excellent" or "good", based on clinical and bacteriological response pre- and post-treatment. Amox Amoxicillin; Amox/clav Amoxicillin/clavulanic acid; Amox/oflox Amoxicillin/ofloxacin; Cipro Ciprofloxacin; Doxy Doxycycline; Duration Length of treatment; NA Information not available; Oflox Ofloxacin; ROXI Roxithromycin; S Sparfloxacin; UTI Urinary tract infection

success for sparfloxacin was $85 \%$ in the study by DeAbate et al (177) and $87 \%$ in the study by Allegra et al (178). The follow-up success rate at 10 days post-treatment was $79 \%(177)$. Sparfloxacin was shown to be at least as effective as the two comparators, ofloxacin and amoxicillin/clavulanic acid, in producing a clinical cure and eradicating the causative pathogens $(177,178)$. In the study by Allegra et al $(178)$, the eradication rate for bacteriologically evaluable patients was $86.4 \%$ for sparfloxacin and $82.1 \%$ for amoxicillin/clavulanic acid. The bacteria most frequently isolated in these two studies included $S$ pneumoniae, $H$ influenzae, $M$ catarrhalis, $C$ pneumoniae, $H$ parainfluenzae, $P$ aeruginosa and the Enterobacteriaceae $(177,178)$. In a study by Taytard et al $(177)$, the overall efficacy of sparfloxacin $(86 \%)$ was equivalent to the overall efficacy of amoxicillin/clavulanic acid (85\%). This study did not provide a microbiological analysis (179).

Six studies, two of which were available as abstracts, have been conducted to examine the efficacy of sparfloxacin in community-acquired pneumonia (180-185). Clinically, sparfloxacin has demonstrated comparable efficacy to amoxicillin, amoxicillin/clavulanic acid, erythromycin, cefaclor and amoxicillin with ofloxacin, and superior efficacy with roxithromycin. The success rate for sparfloxacin in these trials ranged from $84 \%$ to $95 \%$, depending in part on how long after treatment the patients were evaluated. Additionally, sparfloxacin was found to display a superior bacteriological response over erythromycin (91.7\% versus $75.9 \%$ ) (181) and cefaclor $(91.9 \%$ versus $83.8 \%$ ) (182), and at least an equivalent bacteriological response to the other comparators. The predominant pathogens isolated included $S$ pneumoniae, $H$ influenzae, $M$ pneumoniae, $C$ pneumoniae and $H$ parainfluenzae (180-185).

Trovafloxacin: Trovafloxacin (Table 7.6) has been studied as a treatment for pneumonia in several trials. Two prospective, randomized, double-blind trials have been published examining the efficacy of trovafloxacin in the treatment of community-acquired pneumonia $(186,187)$. In these trials, 
TABLE 7.6

Results of clinical trials involving trovafloxacin

\begin{tabular}{|c|c|c|c|c|c|c|}
\hline $\begin{array}{l}\text { Author } \\
\text { (reference) }\end{array}$ & Design & n () & Indication & Regimen & Duration & Results \\
\hline \multicolumn{7}{|c|}{ Respiratory tract infections } \\
\hline $\begin{array}{l}\text { Niederman et } \\
\text { al (186) } \\
\text { (Abst) }\end{array}$ & $\begin{array}{l}\text { Prospective, } \\
\text { randomized, } \\
\text { double-blind }\end{array}$ & $433(362)$ & $\begin{array}{l}\text { Community- } \\
\text { acquired } \\
\text { pneumonia }\end{array}$ & $\begin{array}{l}\text { A: } 200 \text { mg iv every day } \\
\text { followed by T } 200 \text { mg oral } \\
\text { every day }\end{array}$ & 7 to 14 days & A/T: 160/178 (90\%) \\
\hline \multirow{2}{*}{$\begin{array}{l}\text { Sullivan et al } \\
\text { (187) (Abst) }\end{array}$} & \multirow{2}{*}{$\begin{array}{l}\text { Prospective, } \\
\text { randomized, } \\
\text { double-blind }\end{array}$} & \multirow{2}{*}{$359(300)$} & \multirow{2}{*}{$\begin{array}{l}\text { Community- } \\
\text { acquired } \\
\text { pneumonia }\end{array}$} & Clarithro: 500 mg oral bid & 7 to 10 days & $\begin{array}{l}\text { Clarithro: } 147 / 156(94 \%) \\
\text { Day } 30 \text { of study success* } \\
\text { T: } 89 \% \\
\text { Clarithro: } 86 \% \\
\text { (no } \mathrm{Cl} \text { or } \mathrm{P}, \text { but regimens } \\
\text { are "statistically } \\
\text { equivalent") }\end{array}$ \\
\hline & & & & & & End of treatment success ${ }^{\dagger}$ \\
\hline \multirow[t]{3}{*}{$\begin{array}{l}\text { Mandell et al } \\
\text { (188) (Abst) }\end{array}$} & \multirow{3}{*}{$\begin{array}{l}\text { Summary of six } \\
\text { multicentre, } \\
\text { double-blind, } \\
\text { comparative clinical } \\
\text { trials }\end{array}$} & \multirow[t]{3}{*}{257 (NA) } & \multirow{3}{*}{$\begin{array}{l}\text { Community- } \\
\text { acquired } \\
\text { pneumonia caused } \\
\text { by Streptococcus } \\
\text { pneumoniae }\end{array}$} & $\begin{array}{l}\text { A: } 200 \mathrm{mg} \text { iv every day } \\
\text { (2 trials) }\end{array}$ & 7 to 14 days & A/T: $93 \%$ \\
\hline & & & & $\begin{array}{l}\text { T: } 200 \mathrm{mg} \text { oral every day } \\
\text { (4 trials) }\end{array}$ & 7 to 10 days & \\
\hline & & & & & & End to treatment success* \\
\hline \multirow[t]{3}{*}{$\begin{array}{r}\text { Graham et al } \\
\text { (189) (Abst) }\end{array}$} & \multirow[t]{3}{*}{$\begin{array}{l}\text { Prospective, } \\
\text { randomized, } \\
\text { Double-blind }\end{array}$} & \multirow[t]{3}{*}{$267(191)$} & \multirow[t]{3}{*}{$\begin{array}{l}\text { Nosocomial } \\
\text { pneumonia }\end{array}$} & $\begin{array}{l}\text { A: } 300 \text { mg iv every day } \\
\text { followed by T } 200 \text { mg oral } \\
\text { every day }\end{array}$ & 10 to 14 days & A/T: 68/88 (77\%) \\
\hline & & & & $\begin{array}{l}\text { Cipro: iv bid followed by } \\
\text { oral with or without clinda } \\
\text { or metro (no dosage } \\
\text { given) }\end{array}$ & 10 to 14 days & Cipro: 80/103 (78\%) \\
\hline & & & & $\begin{array}{l}\text { Aztreonam or vancomycin } \\
\text { could be added to either } \\
\text { group for documented } \\
\text { Psuedomonas aeruginosa } \\
\text { or MRSA, respectively }\end{array}$ & & $\begin{array}{l}\text { Day } 30 \text { of study success }{ }^{\ddagger} \\
\text { A/T: } 69 \% \\
\text { Cipro: } 68 \% \text { (no } \mathrm{Cl} \text { or } \mathrm{P} \text {, but } \\
\text { the regimens are } \\
\text { "statistically equivalent") }\end{array}$ \\
\hline \multicolumn{7}{|c|}{ Genitourinary tract infections } \\
\hline & & & & & & $\begin{array}{l}\text { At 5- to 9-days } \\
\text { post-treatment }\end{array}$ \\
\hline $\begin{array}{l}\text { Hook et al } \\
\text { (205) }\end{array}$ & $\begin{array}{l}\text { Prospective, } \\
\text { randomized, open, } \\
\text { noncomparative, } \\
\text { dose ranging study }\end{array}$ & $39(31)$ & $\begin{array}{l}\text { Uncomplicated } \\
\text { gonorrhea }\end{array}$ & $\begin{array}{l}\text { T: } 50 \mathrm{mg} \text { oral single dose } \\
(\mathrm{n}=9) \\
\text { T: } 100 \mathrm{mg} \text { oral single dose } \\
(\mathrm{n}=12) \\
\text { T: } 200 \mathrm{mg} \text { oral single dose } \\
(\mathrm{n}=10)\end{array}$ & Single dose & $\begin{array}{l}\text { T: } 100 \% \text { cure for all three } \\
\text { regimens (as defined by } \\
\text { post-treatment culture } \\
\text { results) }\end{array}$ \\
\hline
\end{tabular}


TABLE 7.6 (continued)

Results of clinical trials involving trovafloxacin

\begin{tabular}{|c|c|c|c|c|c|c|}
\hline Study & Design & n () & Indication & Regimen & Duration & Results \\
\hline \multirow{3}{*}{$\begin{array}{l}\text { Jones et al } \\
\text { (206) }\end{array}$} & \multirow{3}{*}{$\begin{array}{l}\text { Prospective, } \\
\text { randomized, } \\
\text { double-blind }\end{array}$} & \multirow{3}{*}{$\begin{array}{l}625 \text { (394 } \\
\text { clinically } \\
\text { evaluable) }\end{array}$} & \multirow{3}{*}{$\begin{array}{l}\text { Uncomplicated } \\
\text { gonococcal } \\
\text { urethritis or } \\
\text { cervicitis }\end{array}$} & & & $\begin{array}{l}\text { 5- to 9-day post-treatment } \\
\text { success }^{\ddagger}\end{array}$ \\
\hline & & & & $\mathrm{T}: 100 \mathrm{mg}$ oral single dose & Single dose & T: 174/182 (96\%) \\
\hline & & & & $\begin{array}{c}\text { Oflox: } 400 \mathrm{mg} \text { oral single } \\
\text { dose }\end{array}$ & Single dose & $\begin{array}{l}\text { Oflox: } 208 / 212(98 \%) \\
\text { The regimens produced an } \\
\text { "equivalent" clinical } \\
\text { response }(95 \% \mathrm{Cl} \\
\text { calculated, but not } \\
\text { reported); } \mathrm{P} \text { not reported }\end{array}$ \\
\hline
\end{tabular}

n) Number of patients (number of patients with complete data at the end of treatment or at follow-up if there was no evaluation at the end of treatment). Where $n$ appears under regimen or indication, it refers to the number of clinically evaluable patients who received the treatment or had the condition. *Success defined as cure (resolution of baseline signs and symptoms) or improvement (partial resolution and no further antibiotic therapy required). ${ }^{\dagger}$ Definition of

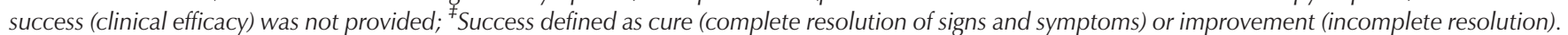
A Alatrofloxacin; Amox Amoxicillin; Ampi/amox Ampicillin/amoxicillin; C Comparators; Ceft Ceftriaxone; Cefpo Cefpodoxime; Cipro Ciprofloxacin; Clarithro Clarithromycin; Clinda Clindamycin; Duration Length of treatment Erythro Erythromycin; iv Intravenous; Metro Metronidazole; MRSA Methicillin-resistant Staphylococcus aureus; NA Information not available; Oflox Ofloxacin; T Trovafloxacin

trovafloxacin alone or trovafloxacin and alatrofloxacin were found to be statistically equivalent to the comparators ceftriaxone/cefpodoxime with or without erythromycin and clarithromycin in terms of producing a successful clinical outcome (Table 7.6) $(186,187)$. In the trial conducted by Niederman et al (186), the isolated pathogens included $S$ pneumoniae, $H$ influenzae, $S$ aureus, $M$ catarrhalis, $L$ pneumophila, $M$ pneumoniae and $C$ pneumoniae. Alatrofloxacin, followed by trovafloxacin, was shown to be as effective in the microbiologically evaluable patients as the alternative regimen of ceftriaxone/cefpodoxime with or without erythromycin (186). A summary of six trials in which trovafloxacin (or alatrofloxacin) was used to treat community-acquired pneumonia caused by $S$ pneumoniae revealed that the clinical efficacy of trovafloxacin/alatrofloxacin was $93 \%$ at the end of treatment and $91 \%$ at follow-up. The combined results for the comparators in the six trials were $94 \%$ and $88 \%$, respectively (comparators are listed in Table 7.6). A statistical analysis of these results was not provided (188). When trovafloxacin/alatrofloxacin was investigated for the treatment of nosocomial pneumonia, the clinical success was $77 \%$ of those treated with trovafloxacin/alatrofloxacin versus $78 \%$ of those treated with ciprofloxacin with or without clindamycin or metronidazole. The two regimens were reported to be statistically equivalent. A microbiological analysis was not provided (189).

Genitourinary tract infections - Clinafloxacin: Data are not available on the use of clinafloxacin to treat genitourinary tract infections.

Gatifloxacin: One open noncomparative trial was identified examining the efficacy of gatifloxacin in the treatment of genitourinary tract infections (Table 7.2). Suzuki et al (190) investigated the use of gatifloxacin to treat chronic bacterial prostatitis and reported its overall efficacy to be $91 \%$. Additionally, bacterial eradication was achieved against $100 \%$ of the strains isolated. Bacteria were cultured from expressed prostatic secretions. The bacteria isolated in this trial included $E$ coli, Enterococcus faecalis, Staphylococcus epidermidis and Strepto- coccus agalactiae. Three of nine patients available for follow-up relapsed within two to four weeks. This led the investigators to suggest that a longer course of therapy, beyond the 14 days used in this study, may be required (190).

Grepafloxacin: Three trials have been conducted in which grepafloxacin has been used to treat genitourinary tract infections (Table 7.3) (191-193). The first of these compared grepafloxacin with cefixime in the treatment of uncomplicated gonorrhea in men. This study found that both drugs produced high cure rates ( $99 \%$ for grepafloxacin and $97 \%$ for cefixime) as defined by eradication of the causative pathogen, $N$ gonorrhoeae (191). Another study, published in abstract form, examined the efficacy of grepafloxacin relative to ofloxacin in 244 patients with gynecologcal infections. It was found that the two drugs were similar in terms of clinical and bacteriological efficacy (Table 7.3) (192). The third study was a dose ranging study investigating the treatment of Chlamydia trachomatis infections in women who were using grepafloxacin. This study found grepafloxacin to be effective, as determined by a reduction in signs and symptoms of infection and negative culture results at the follow-up visit (193). In addition, Mroczkowski et al (194), published as an abstract, demonstrated comparable clinical success for a single dose of grepafloxacin $400 \mathrm{mg}$ and cefixime $400 \mathrm{mg}$ in the treatment of gonococcal cervicitis in women.

Levofloxacin: The efficacy of levofloxacin in the treatment of genitourinary tract infections has been the subject of a small number of trials (Table 7.4). The results from two studies in which levofloxacin was used to treat acute pyelonephritis were combined and analyzed. Levofloxacin produced a clinical success rate of $93 \%$ versus $95 \%$ for ciprofloxacin and lomefloxacin, which were used as comparators. Against the pathogens most commonly isolated in the two trials, E coli, Klebsiella pneumoniae and Staphylococcus saprophyticus, levofloxacin was found to be at least as effective as ciprofloxacin and lomefloxacin (195). The use of levofloxacin to treat complicated urinary tract infections was investigated by Klimberg et al (196). Levo- 
floxacin produced a clinical success (defined as cure or improvement) in $93 \%$ of patients versus $88 \%$ for lomefloxacin, which was used as a comparator. The eradication rate produced by levofloxacin (98.9\%) against $E$ coli, the pathogen most frequently isolated in this study, was not significantly different from the eradication rate produced by lomefloxacin (97.6\%) against this pathogen (196). Levofloxacin has also been investigated in the treatment of nonchlamydial chronic prostatitis. Levofloxacin produced a clinical success rate of $75 \%$. This trial was noncomparative and involved a relatively small number of participants (197).

Sparfloxacin: Seven studies have been carried out examining the efficacy of sparfloxacin in the treatment of genitourinary tract infections (Table 7.5) (198-204). Sparfloxacin has been compared with ciprofloxacin in the treatment of acute gonococcal urethritis in men. Efficacy, defined in part by the eradication of $N$ gonorrhoeae, was achieved in $99 \%$ of patients treated with sparfloxacin and in $98 \%$ of patients treated with ciprofloxacin (198). Phillips et al (199) investigated two regimens of sparfloxacin as a treatment for nongonococcal urethritis in men. Overall, both regimens were found to be statistically equivalent to doxycycline, which was used as the comparator. $C$ trachomatis and $U$ urealyticum were the pathogens isolated in this study. The eradication of $C$ trachomatis, specifically, was not as high at follow-up in the three-day sparfloxacin group $(88.1 \%)$ as it was in the seven-day sparfloxacin group (97\%) or doxycycline group (96.1\%) (199).

Three trials have focused on the treatment of urinary tract infections with sparfloxacin (200-202). Naber et al (200) studied sparfloxacin in the treatment of complicated urinary tract infections. The overall efficacy of sparfloxacin (71\%) was found to be lower than the overall efficacy of ciprofloxacin (77\%). Sparfloxacin was significantly less effective than ciprofloxacin in producing a bacteriological cure. These results were attributed to a lower activity of sparfloxacin against Enterobacteriaceae (other than $E$ coli), P aeruginosa and enterococci (200). Sparfloxacin has been used to treat community-acquired, acute, uncomplicated urinary tract infections in two studies, published as abstracts. Both one-day and three-day regimens of sparfloxacin produced a successful clinical response in about $93 \%$ of patients. Sparfloxacin was found to be equivalent to ciprofloxacin and ofloxacin in producing a clinical response $(201,202)$.

An open label, noncomparative trial investigated the efficacy of sparfloxacin in treating uncomplicated urinary tract infections, complicated urinary tract infections, urethritis and prostatitis. Clinical efficacy was $100 \%, 65 \%, 93 \%$ and $79 \%$, respectively, in patients treated for these infections. Several dosage regimens were used in this trial. Clinical efficacy in the patients that received $300 \mathrm{mg}$ once daily was found to be higher than that in patients who received $200 \mathrm{mg}$ once daily (203).

The efficacy of sparfloxacin in treating gynecological infections has been the subject of a single, noncomparative trial available as an extended abstract (204). Sparfloxacin produced a clinical response that was either 'excellent' or 'good' in $97 \%$ of patients with adnexitis, $94 \%$ of patients with endometritis, $98 \%$ of patients with cervicitis and $100 \%$ of patients with other gynecological infections. The pathogens iso- lated in this study included Gram-positive bacteria, Gram-negative bacteria and anaerobes. Overall, $91.3 \%$ of the bacterial strains isolated were eradicated by treatment with sparfloxacin (204).

Trovafloxacin: The efficacy of trovafloxacin in the treatment of genitourinary tract infections has been evaluated in two trials (Table 7.6$)(205,206)$. The first of these was a noncomparative dose ranging study that examined the use of trovafloxacin in the treatment of uncomplicated gonorrhea. It was found that all three dosage regimens produced a cure in $100 \%$ of patients treated, as determined by post-treatment culture results (205). Jones et al (206) conducted another trial involving a larger number of patients. In this prospective, randomized, doubleblind trial, trovafloxacin was used to treat patients with uncomplicated gonococcal urethritis or cervicitis. Eradication rates and clinical responses in the trovafloxacin group were equivalent to those in the ofloxacin group. Ninety-six per cent of patients treated with trovafloxacin showed a clinical response of either cure or improvement (206).

Skin and skin structure infections - Clinafloxacin: Data are not available on the use of clinafloxacin to treat skin and skin structure infections.

Gatifloxacin: Data are not available on the use of gatifloxacin to treat skin and skin structure infections.

Grepafloxacin: The use of grepafloxacin in treating skin and skin structure infections has been investigated in one trial ( $\mathrm{Ta}$ ble 7.3) (207). Patients enrolled in this study had either deepseated hair follicle infections (eg, furunculosis) or deep-seated diffuse infections (eg, cellulitis). Grepafloxacin was found to be $90 \%$ efficacious in treating these patients, and was equivalent to ofloxacin in the treatment of skin and skin structure infections. Criteria used to evaluate efficacy were not described in the abstract (207).

Levofloxacin: Two trials were identified that examined the use of levofloxacin for the treatment of skin and skin structure infections (Table 7.4). In a randomized trial performed by Nicodemo et al (208), levofloxacin was compared with ciprofloxacin in the treatment of uncomplicated infections, which included abscesses, impetigo, furuncles, cellulitis and pyoderma. The most common pathogens isolated were Grampositive aerobes (S aureus and Streptococcus pyogenes). Levofloxacin and ciprofloxacin were found to be equivalent, both clinically and microbiologically. The clinical success rates of levofloxacin and ciprofloxacin were $96 \%$ and $94 \%$, respectively (208). Nichols et al (209) conducted another trial comparing levofloxacin with ciprofloxacin in the treatment of skin and skin structure infections. In this study, cellulitis was the most common diagnosis in both treatment groups, occurring in approximately $47 \%$ of patients. Treatment with levofloxacin resulted in a clinical success (cure or improvement) in 98\% (178 of 182) of patients versus 94\% (182 of 193) for ciprofloxacin (209).

Sparfloxacin: The efficacy of sparfloxacin in the treatment of skin and skin structure infections has been studied in three trials (all published as abstracts) (210-212) (Table 7.5). In the first of these, the clinical response rate of sparfloxacin was statistically equivalent to that of ciprofloxacin, with $90 \%$ of sparfloxacin-treated patients and $87 \%$ of ciprofloxacin-treated 
TABLE 8

Frequently occurring adverse effects of the new fluoroquinolones and ciprofloxacin

\begin{tabular}{|c|c|c|c|c|c|c|c|c|}
\hline \multirow[b]{2}{*}{ Adverse effect } & \multicolumn{8}{|c|}{ Fluoroquinolone } \\
\hline & Ciprofloxacin & Clinafloxacin & Gatifloxacin & Grepafloxacin & Levofloxacin & Moxifloxacin & Sparfloxacin & Trovafloxacin \\
\hline \multicolumn{9}{|l|}{ Gastrointestinal } \\
\hline Nausea & + & ND & + & ++ & + & ++ & + & ++ \\
\hline Diarrhea & + & ++ & + & + & + & ++ & + & + \\
\hline \multicolumn{9}{|l|}{ Central nervous system } \\
\hline Dizziness & + & ND & + & + & - & $+/-$ & - & +++ \\
\hline Rash & + & ND & ND & + & - & $+/-$ & + & $+/-$ \\
\hline Pruritis & $+/-$ & ND & ND & + & - & $+/-$ & $+/-$ & $+/-$ \\
\hline Phototoxicity & $+/-$ & ++ & $+/ N D$ & + & $+/-$ & $+/-$ & ++ & $+/-$ \\
\hline $\begin{array}{l}\text { Cardiovascular } \\
\text { (QTc prolongation)* }\end{array}$ & - & ND & ND & + & - & - & ++ & ND \\
\hline Taste perversion & - & ND & ND & +++ & $+/-$ & - & - & ND \\
\hline
\end{tabular}

*Percentages of patients experiencing this side effect have not been documented for both sparfloxacin and grepafloxacin. The relative number of " + " symbols here only indicates that there are more reports of this side effect with sparfloxacin. - Side effect has not been observed; +/-Side effect occurs in less than $1 \%$ of patients; + Side effect occurs in $1 \%$ to $5 \%$ of patients; + + Side effect occurs in $6 \%$ to $10 \%$ of patients; + + + Side effect occurs in more than $10 \%$ of patients; +/ND Side effect is expected to occur but has not been documented yet. For clinafloxacin, gatifloxacin, moxifloxacin and trovafloxacin, because these agents have not been extensively studied in clinical trials, if a specific side effect was not found to be reported a 'ND' was entered into the table. For ciprofloxacin, grepafloxacin, levofloxacin and sparfloxacin, a '-' was entered into the Table if a specific side effect was not found to be reported because these agents have been extensively studied in clinical trials. NA Not applicable (fluoroquinolone is not available in an intravenous formulation); ND No data. Adapted from references 6,144,145,162-164,166,169,171,190,213,216-224

patients cured or improved. Sparfloxacin demonstrated a higher bacterial eradication rate than ciprofloxacin $(87 \%$ versus $80 \%$ ). A statistical analysis of this result was not provided. Gram-positive cocci were the most frequently isolated pathogens in this study (210). The remaining two studies were noncomparative. In both of these trials, treatment with sparfloxacin resulted in an 'excellent' or 'good' clinical response in $87 \%$ of patients $(211,212)$. Overall, sparfloxacin displayed an eradication rate of $92.7 \%$ in the study conducted by Watanabe et al (212). The most common pathogens isolated in this study were coagulase-negative staphylococci, $S$ aureus and E coli (212).

Trovafloxacin: Data are not available on the use of trovafloxacin to treat skin and skin structure infections.

Intra-abdominal infections - Clinafloxacin: Clinafloxacin has excellent activity against Gram-positive and Gramnegative aerobes and anaerobes (see section on In Vitro Activity), making it a potentially useful therapy in the treatment of intra-abdominal infections (Table 7.1). Wilson (213) conducted a study of intra-abdominal infections from a variety of causes, including appendicitis, bowel perforation and diverticulitis. Results demonstrated a cure rate of $76 \%$ in the evaluable population. Furthermore, clinafloxacin was found to be equally as efficacious as imipenem in the treatment of intraabdominal infections (213).

\section{OVERALL EVALUATION}

Traditionally, the fluoroquinolones have been considered to have only moderate activity against streptococci. Consequently, older fluoroquinolones are not first-line agents in the treatment of lower respiratory tract infections. A recent review of ciprofloxacin presents convincing evidence that this drug may not be significantly different from comparators in the treatment of lower respiratory tract infections (6). However, because there is increased concern with the development of pencillin-resistant $S$ pneumoniae, new fluoroquinolones with good activity against $S$ pneumoniae are of interest. The new fluoroquinolones appear to perform well in vivo. They are considered as part of the therapeutic regimens for the treatment of community-acquired pneumonia as indicated in the recent management guidelines from the Infectious Diseases Society of America (214).

The new fluoroquinolones that have been studied in the treatment of genitourinary tract, and skin and skin structure infections have also yielded promising results. These agents were all found to be at least as efficacious as their comparators. However, it should be stated that fluoroquinolones are an evolving treatment for skin and soft tissue infections, while cloxacillin, clindamycin, cephalexin, etc, remain excellent first-line choices. Several of the new fluoroquinolones demonstrate improved activity against anaerobes (clinafloxacin, gatifloxacin, moxifloxacin, sparfloxacin and trovafloxacin). These agents may be suitable for the treatment of anaerobic, or mixed aerobic/anaerobic infections. Clinafloxacin has demonstrated favourable results in one study where it was used to treat intra-abdominal infections.

Overall, the clinical efficacy of the new fluoroquinolones is very promising. Based on the dosage regimens used in clinical trials, once daily dosing appears to be appropriate with a number of these agents. Adverse effects, drug interactions, pharmacokinetics and cost also play a major role in decisionmaking, and these are discussed in other sections of this review. In addition, it is very important to consider the wide 
scale use of fluoroquinolones in the context of the potential for development of antimicrobial resistance. High level resistance to one fluoroquinolone ensures resistance to all others (except clinafloxacin) (215). Although the new fluoroquinolones may seem ideal for multiple indications, it is important to reserve their use for specific indications where other conventionally used agents would not be suitable.

\section{ADVERSE EFFECTS}

Gastrointestinal side effects, central nervous system disturbances and allergic manifestations are the most frequently encountered adverse effects of the new fluoroquinolones (Table 8) $(6,143,144,161-163,165,167,171,189,213,216-224)$. Because a direct comparison between the various agents has not been performed in clinical trials, the data represent the approximate frequency of adverse effects with which side effects have been reported in the literature. The new fluoroquinolones for which data exist have all been observed to cause nausea, vomiting and diarrhea to some degree (Table 8).

Central nervous system side effects: Central nervous system side effects, specifically dizziness and headache, have been reported for many of the new fluoroquinolones (Table 8). Trovafloxacin causes the highest incidence of dizziness (approximately 11\%) (223). Levofloxacin and sparfloxacin have to date not been observed to produce this particular adverse effect. The incidence of headache resulting from treatment with the new fluoroquinolones is similar for all of the agents for which data were available, with roughly $1 \%$ to $5 \%$ of patients treated reporting this side effect (Table 8).

Allergic reactions: Rash and pruritis have been reported relatively frequently for several of the new fluoroquinolones (Table 8). These adverse effects have not been observed for levofloxacin.

Cardiovascular side effects: Grepafloxacin and sparfloxacin have both been observed to cause prolongation of the QTc interval $(218,222)$. Little data exist on the clinical relevance of this adverse effect for grepafloxacin. Sparfloxacin causes a $3 \%$ increase in the QTc interval on average, and this is not increased in patients with impaired hepatic or renal function (222). These two fluoroquinolones should be used with extreme caution, if at all, in patients with underlying cardiac conditions, such as pre-existing QT prolongation, and in patients taking other medications known to prolong the QTc interval (see section on Drug Interactions) $(218,222,225)$.

Phototoxicity: Phototoxicity, a class effect common to all of the fluoroquinolones, appears to result from an interaction between ultraviolet A (UVA) light and the fluoroquinolone molecule. This interaction produces photodegredation products and/or reactive oxygen species that may result in tissue damage $(5,226)$. Clinafloxacin and sparfloxacin cause a significantly higher incidence of phototoxicity than the other agents ( $1.5 \%$ to $14 \%$ and $2 \%$ to $11 \%$, respectively) $(213,227)$. The phototoxic potential of the new fluoroquinolones is approximately sparfloxacin equal to clinafloxacin much greater than grepafloxacin greater than levofloxacin equal to ciprofloxacin greater than trovafloxacin $(13,213,216,217,217,224,228)$. Not enough data have been collected on gatifloxacin or moxi- floxacin to include them in this ranking. The phototoxicity of sparfloxacin is particularly severe, and in France and Japan, approximately $10 \%$ to $15 \%$ of phototoxicity cases involving sparfloxacin have been serious, requiring hospitalization (227). Measures to prevent this adverse effect include avoiding UVA sunlight, wearing protective clothing and using a broad spectrum sunscreen that blocks UVA light even on cloudy days and with window glass-transmitted sunlight (5).

Hepatotoxicity: Recently, 53 cases of hepatotoxicity have been reported with trovafloxacin (personal communication, Pifzer Inc). With over 1,200,000 patients who have received trovafloxacin, this yields a frequency of approximately one in 20,000 cases. Hepatotoxicity has ranged from asymptomatic elevations in hepatic enzymes to clinical jaundice. The majority of these patients had pre-existing hepatic abnormalities or were receiving concomitant potential hepatotoxins (personal communication, Pfizer Inc). The exact role that trovafloxacin has in causing or contributing to hepatotoxicity needs to be better delineated.

Paediatric concerns: The fluoroquinolones are contraindicated in children, in adolescents in the growing phase, and during pregnancy and lactation (229). The reason for these contraindications is that many of the older fluoroquinolones have been observed to induce cartilage toxicity when administered to immature animals. When the animals presented with clinical symptoms, the joint lesions presented as acute arthritis, with limping and swelling (230). Cartilage toxicity in animals appears to be caused by all of the fluoroquinolones to some degree. However, it appears that fluoroquinolones only very rarely cause arthropathy in humans (230). In a review that examined the adverse effects documented in more than 1500 children and adolescents who were administered ciprofloxacin, the safety profile of this drug was found to be similar to the safety profile in adults (231). Gastrointestinal, dermatological and central nervous system side effects were the adverse events most commonly observed. Arthralgia was rarely documented and always reversible. In 1113 patients with cystic fibrosis, reversible arthralgia occurred in 36 (3.2\%) (231). Thus, in the treatment of severe, life-threatening diseases, the benefit of fluoroquinolone use in children appears to outweigh the risk (229). However, because the potential to cause harm exists, further study is needed before the fluoroquinolones can be recommended for routine use in paediatric patients. A study by Martell et al (232) assessed whether growth of preterm infants was affected by administration of a fluoroquinolone. This study reported lower weight and smaller head circumference in the fluoroquinolone-treated individuals, relative to a reference group. It was not clear whether this was due to treatment with a fluoroquinolone or another variable such as the severity of illness (232).

\section{DRUG INTERACTIONS}

A number of studies have been published examining potential interactions between the new fluoroquinolones and various other drugs. Table 9 presents some of the more common and/or potentially serious drug interactions of the new fluoroquinolones $(6,9,13,129,218,222,231-251)$. 
TABLE 9

Drug interactions of the new fluoroquinolones

\begin{tabular}{|c|c|c|c|c|c|c|c|c|}
\hline \multirow[b]{2}{*}{ Interaction with } & \multicolumn{8}{|c|}{ Fluoroquinolone } \\
\hline & Ciprofloxacin & Clinafloxacin & Gatifloxacin & Grepafloxacin & Levofloxacin & Moxifloxacin & Sparfloxacin & Trovafloxacin \\
\hline $\begin{array}{l}\text { Metal ion-containing drugs } \\
\text { (eg antacids, iron, } \\
\text { sucralfate) }\end{array}$ & Yes & Yes* & Yes & Yes* & Yes & Yes & Yes & Yes \\
\hline Mechanism & \multicolumn{8}{|c|}{ Chelation resulting in reduced fluoroquinolone bioavailability } \\
\hline Recommendation & \multicolumn{8}{|c|}{$\begin{array}{l}\text { Avoid concomitant administration if possible. Otherwise, administer the fluoroquinolone } 2 \mathrm{~h} \text { before or } 6 \mathrm{~h} \text { after the metal } \\
\text { ion containing drug. }\end{array}$} \\
\hline Recommendation & \multicolumn{8}{|c|}{$\begin{array}{l}\text { For ciprofloxacin and clinafloxacin, monitor theophylline levels and adjust theophylline dosage where necessary. For } \\
\text { grepafloxacin, reduce theophylline dosage by } 50 \% \text { and monitor theophylline levels. For levofloxacin, moxifloxacin, } \\
\text { sparfloxacin and trovafloxacin, monitor for clinical signs of theophylline toxicity. }\end{array}$} \\
\hline Warfarin & $\mathrm{Yes} / \mathrm{No}^{\ddagger}$ & ND & ND & No & $\mathrm{No}^{\S}$ & No & No & No \\
\hline Mechanism & \multicolumn{8}{|c|}{ Reduced metabolism of warfarin } \\
\hline Recommendation & \multicolumn{8}{|c|}{ For ciprofloxacin, monitor prothrombin time or another suitable coagulation parameter. } \\
\hline Mechanism & \multirow{2}{*}{\multicolumn{8}{|c|}{$\begin{array}{l}\text { Additive prolongation of the QTC interval } \\
\text { For grepafloxacin and sparfloxacin, avoid concomitant administration with other drugs know to cause prolongation of the } \\
\text { QTC interval. }\end{array}$}} \\
\hline Recommendation & & & & & & & & \\
\hline
\end{tabular}

*Theoretical interaction, not actually documented by studies. ${ }^{\dagger}$ For theophylline: $+10 \%$ to $50 \%$ increase in theophylline peak concentration reached in the plasma/serum $\left(C_{\max }\right)$ and area under the plasma concentration time curve $(A \cup C),++$ greater than $50 \%$ increase in theophylline $C_{\max }$ and $A \cup C ;++/ N D$ greater than $50 \%$ increase in theophylline concentrations, but only one case report has been published on the interaction. ${ }^{*}$ Interaction has been reported rarely. Interaction with levofloxacin studied using a single dose of warfarin. ND No data. Adapted from references 6,9,13,129,218,222,233-251

Metal ion-containing drugs: Interactions have been observed (or are anticipated to occur) between metal ion-containing drugs and all members of the fluoroquinolone class of antibiotics (Table 9).

These interactions are thought to be predominantly the result of chelate (complex) formation between polyvalent metal cations and the fluoroquinolone molecules (8,17-19). The chelates formed are insoluble, and, thus, the bioavailability of the fluoroquinolones is decreased (18). Metal ion-containing drugs that interact with the new fluoroquinolones include aluminumand magnesium-containing antacids, ferrous sulphate and sucralfate, which is a complex of aluminum hydroxide and sulphated sucrose (18). Metal ion-containing drugs have been reported to cause a reduction in fluoroquinolone bioavailability ranging from $19 \%$ to $88 \%$, depending on the specific metal ion-containing drug and the specific fluoroquinolone (6,129,233-239). Iron has less of an impact than sucralphate and antacids $(17,18,233)$. It is uncertain as to whether calcium affects the bioavailability of the new fluoroquinolones to any extent. To avoid therapeutic failure, concomitant administration of metal ion-containing drugs and fluoroquinolones should be avoided $(6,18,235)$. If this is not feasible, the fluoroquinolone should be administered at least $2 \mathrm{~h}$ before or $6 \mathrm{~h}$ after the ingestion of the metal ion-containing drug $(6,236,240)$.

Theophylline: The metabolic enzyme cytochrome P450 1A2 can be inhibited by several of the fluoroquinolones (ciprofloxacin, clinafloxacin, grepafloxacin), resulting in reduced clearance of theophylline $(241,242)$. This can lead to increased serum theophylline levels and potential toxicity $(6,241)$. A $600 \mathrm{mg}$ daily dose of ciprofloxacin has been observed to cause an increase in the $\mathrm{C}_{\max }$ and AUC of theophylline of $17 \%$ and $22 \%$, respectively (242). Clinafloxacin (200 mg every $12 \mathrm{~h}$ ) was reported to produce a more than doubling of serum theophylline concentration in one case report (241). Finally, grepafloxacin (600 mg every day) has been reported to increase the $C_{\max }$ of theophylline by $82 \%$ and to decrease the total theophylline clearance by about 50\% (243). Levofloxacin, moxifloxacin, sparfloxacin and trovafloxacin have not been observed to produce a clinically significant increase in theophylline levels (242,244-248). If ciprofloxacin or clinafloxacin is administered to a patient on theophylline, theophylline levels should be monitored and the dosage of theophylline adjusted when necessary $(6,241)$. For concomitant grepafloxacin therapy, the dosage of theophylline should be reduced by $50 \%$ and theophylline levels monitored (243). Monitoring of theophylline levels is not necessary for the other agents when coadministered with theophylline. However, the patient should still be monitored for clinical signs of theophylline toxicity (13).

Warfarin: Ciprofloxacin has been reported to decrease the metabolism of warfarin (6). The possibility of an interaction with warfarin has been investigated for grepafloxacin, levofloxacin, moxifloxacin, sparfloxacin and trovafloxacin $(9,243,250$, 251). No alteration in the pharmacokinetics or anticoagulant action of warfarin was reported when it was administered concomitantly with each of these five fluoroquinolones $(9,2434,250,251)$.

Phenytoin: An interaction between phenytoin and ciprofloxacin has been reported in a few patients. This interaction is 
TABLE 10

Drugs that have been reported to prolong the $\mathrm{QT}$ interval or induce torsades de points (potential interaction with grepafloxacin and sparfloxacin)

\begin{tabular}{|c|c|}
\hline Class & Drugs \\
\hline \multicolumn{2}{|l|}{ Antiarrhythmics } \\
\hline Class la & Disopyramide, procainamide, quinidine \\
\hline Class III & Amiodarone, bretylium, sotalol \\
\hline Antimicrobials & $\begin{array}{l}\text { Erythromycin, } \\
\text { trimethoprim/sulfamethoxazole }\end{array}$ \\
\hline Antihistamines & Astemizole, terfenadine \\
\hline $\begin{array}{l}\text { Antimalarials or } \\
\text { antiprotozoals }\end{array}$ & $\begin{array}{c}\text { Chloroquine, halofantrine, mefloquine, } \\
\text { pentamidine, quinine }\end{array}$ \\
\hline Prokinetic agents & Cisapride \\
\hline Psychoactive agents & $\begin{array}{c}\text { Chloral hydrate, haloperidol, lithium, } \\
\text { phenothiazines, pimozide, tricyclic } \\
\text { antidepressants }\end{array}$ \\
\hline Others & $\begin{array}{c}\text { Amantadine, probucol, tacrolimus, } \\
\text { vasopressin }\end{array}$ \\
\hline
\end{tabular}

Adapted from reference 249

thought to be the result of reduced metabolism of phenytoin, caused by fluoroquinolone inhibition of the cytochrome $\mathrm{P} 450$ isoenzyme (6). Studies have not yet been conducted to investigate whether any of the new fluoroquinolones also interact with phenytoin.

Drugs prolonging the QT interval: In the adverse effects portion of this review, it was noted that grepafloxacin and especially sparfloxacin may cause QTc interval prolongation $(218,222)$. Torsades de pointes is sometimes proceeded by marked QT prolongation. Hence, grepafloxacin and sparfloxacin should be used with extreme caution, if at all, in patients taking other medications that are known to prolong the QT interval or induce torsades de pointes (Table 10) (249). If these medications are used together, an additive prolongation of the QT interval may result. No reports of torsades de pointes attributed to a drug interaction with grepafloxacin were found in the literature. When sparfloxacin was administered with cisapride (Prepulsid, Janssen-Ortho) in one study, a prolongation of the QTc interval of $7.7 \%$ resulted (129). This is greater than the prolongation of $3 \%$ reported for sparfloxacin alone (222). However, no cardiovascular side effects were noted (129). Terfenadine has also been reported to produce an additive increase in the QTc interval when taken with sparfloxacin (222).

\section{FORMULARY AND PHARMACOECONOMIC CONSIDERATIONS}

Of the newer fluoroquinolones discussed, only levofloxacin, grepafloxacin and trovafloxacin are commercially available in Canada. These are in addition to the currently availalable fluoroquinolones: norfloxacin, ciprofloxacin and ofloxacin. These newer fluoroquinolones differ with respect to spectrum of activity and frequency of administration. Much of the therapeutic focus of the newer fluoroquinolones is on the use of these agents for the treatment of respiratory tract infections, specifically community-acquired pneumonia. Due to the emergence of penicillin-resistant $S$ pneumoniae infections, the
TABLE 11

Cost comparison of commercially available fluoroquinolones in Canada*

\begin{tabular}{|c|c|c|}
\hline Fluoroquinolone & Daily dosage & $\begin{array}{l}\text { Acquisition cost } \\
\text { per day (\$) }\end{array}$ \\
\hline \multicolumn{3}{|l|}{ Oral } \\
\hline Norfloxacin & $400 \mathrm{mg}$ twice daily & 4.36 \\
\hline Ofloxacin & 200-400 mg twice daily & $4.14-4.83$ \\
\hline Ciprofloxacin & 250-750 mg twice daily & $4.44-9.46$ \\
\hline Levofloxacin & 250-500 mg once daily & $4.44-5.01$ \\
\hline Grepafloxacin & 600 mg once daily & 5.64 \\
\hline Trovafloxacin & 100-200 mg once daily & $4.21-5.23$ \\
\hline \multicolumn{3}{|l|}{ Intravenous } \\
\hline Ciprofloxacin & $400 \mathrm{mg}$ iv every $12 \mathrm{~h}$ & 66.00 \\
\hline Levofloxacin & $500 \mathrm{mg}$ iv every $24 \mathrm{~h}$ & 45.00 \\
\hline Alatrofloxacin ${ }^{+}$ & $200-300 \mathrm{mg}$ iv every $24 \mathrm{~h}$ & 42.87-64.15 \\
\hline
\end{tabular}

*Based on manufacturers' listed Canadian price; ${ }^{+}$Prodrug of trovafloxacin. Bold face indicates a new fluoroquinolone. iv Intravenous

role of the newer fluoroquinolones has gained further prominence (252). The challenge, however, for many practitioners, clinicians, and provincial and hospital formularies is to determine the place and role of these new agents in the environment of emerging antibiotic resistance and economic constraints.

The acquisition cost per day for the quinolone class of agents is listed in Table 11. Factors that should influence the use of these agents include local or regional epidemiology, antibiotic resistance, patterns of prescribing, severity of illness, fluoroquinolone considerations (adverse effects, drug interactions), availability of other antibiotic regimens, patient considerations (compliance, dosing convenience) and patient or payer economic considerations. Other ancillary costs such as intravenous admixture costs may also need to be considered. These must be considered when a fluoroquinolone is reviewed for addition to a provincial or hospital formulary.

At this time, there is a paucity of published pharmacoeconomic studies of the newer fluoroquinolones. Although pharmacoeconomic evaluations of the new quinolones have been prepared and submitted by the manufacturer (to provincial formularies, health ministries or hospital formularies), these evaluations were not available to us during this review. Past economic analyses with ciprofloxacin, however, have clearly demonstrated the economic benefits of the fluoroquinolone class of antibiotics (253-255). The majority of these studies have evaluated the role of sequential antibiotic therapy, ie, the conversion of intravenous to oral antibiotic therapy with oral ciprofloxacin in hospitals. Fliegelman and coworkers (255) estimated a reduction in antibiotic acquisition costs from US $\$ 427$ to US $\$ 244 /$ patient while reducing the length of stay by $20 \%$. Paladino and colleagues (254) reported a reduction in treatment cost and resultant cost savings per patient of US\$293 when intravenous therapy was converted from intravenous to oral. Considerations of these analyses included the drug cost, cost of treatment failures, drug prepara- 
tion and administration costs as well as adverse effects. A further retrospective cost effectiveness analysis compared ceftazidime with sequential intravenous or oral ciprofloxacin for the treatment of nosocomial pneumonia (256). Decision analysis found that ciprofloxacin was cost effective compared with ceftazidime.

These findings indicate that the newer fluoroquinolones also offer similar cost benefits when used in sequential oral therapy by decreasing drug therapy costs and potentially decreasing the length of hospital stay for indications studied in the ciprofloxacin trials. Knowledge of the acquisition cost and frequency of administration suggests that the once daily administration of the newer fluoroquinolones may decrease inpatient drug preparation and administration costs while improving patients' out-patient adherence to their antibiotic regimen. However, economic analyses concerning the use of the newer fluoroquinolones for community-acquired pneumonia using Canadian data are not available and cannot be extrapolated from existing studies to the community or outpatient use of these agents.

There is a paucity of data comparing fluoroquinolone with fluoroquinolone. As a result, pharmacoeconomic analysis is often difficult due to a lack of comparative clinical trial data. A report from the Canadian Coordinating Office Health Technology Assessment attempted to evaluate the economics of

\section{REFERENCES}

1. Andriole VT. The future of the quinolones. Drugs $1993 ; 45$ (Suppl 3):1-7.

2. Buchbinder M, Webb JC, Anderson L, McCabe WR. Laboratory studies and clinical pharmacology of nalidixic acid (WIN 18,320). Antimicrob Agents Chemother 1962:308-17.

3. Gillis MC, ed. Compendium of Pharmaceuticals and Specialties. Ottawa: Canadian Pharmacists Association, 1998:318-21,1083-4.

4. Ronald AR, Turck M, Petersdorf RG. A critical evaluation of nalidixic acid in urinary-tract infections. N Engl J Med 1966;275:1081-8.

5. Wainwright NJ, Collins P, Ferguson J. Photosensitivity associated with antibacterial agents. Drug Saf 1993;9:437-40.

6. Davis R, Markham A, Balfour JA. Ciprofloxacin. An updated review of its pharmacology, therapeutic efficacy and tolerability. Drugs 1996;51:1019-74.

7. Neu HC. Chemical evolution of the fluoroquinolone antimicrobial agents. Am J Med 1989;87(Suppl 6C):2S-9S.

8. Domagala JM. Structure-activity and structure-side-effect relationships for the quinolone antibacterials. J Antimicrob Chemother 1994;33:685-706.

9. Goa KL, Bryson HM, Markham A. Sparfloxacin. A review of its antibacterial activity, pharmacokinetic properties, clinical efficacy and tolerability in lower respiratory tract infections. Drugs 1997;53:700-25.

10. Cohen MA, Huband MD, Gage JW, Yoder SL, Roland GE, Gracheck SJ. In-vitro activity of clinafloxacin, trovafloxacin, and ciprofloxacin. J Antimicrob Chemother 1997;40:205-11.

11. Hosaka M, Kinoshita S, Toyama A, Otsuki M, Nishino T. Antibacterial properties of AM-1155, a new 8-methoxy quinolone. J Antimicrob Chemother 1995;36:293-301.

12. Wagstaff AJ, Balfour JA. Grepafloxacin. Drugs 1997;53:817-24.

13. Davis R, Bryson HM. Levofloxacin. A review of its antibacterial activity, pharmacokinetics and therapeutic efficacy. Drugs 1994;47:677-700.

14. Dalhoff A, Petersen U, Endermann R. In vitro activity of BAY 12-8039, a new 8-methoxyquinolone. Chemotheraphy 1996;42:410-25.

15. Brighty KE, Gootz TD. The chemistry and biological profile of trovafloxacin. J Antimicrob Chemother 1997;39(Suppl B):1-14. fluoroquinolones in several indications (257). However, due to the absence of data and limited assumptions, the economic evaluation was only conducted for a three-day treatment of cystitis (257).

\section{CONCLUSIONS}

The new fluoroquinolones offer once daily dosing and a spectrum of activity different from that of existing fluoroquinolones. These differences should be placed in the context of local epidemiology, antibiotic resistance profiles and patterns of antibiotic prescribing (institutional or community). Consideration of the newer fluoroquinolones for a hospital or provincial formulary should take into account the potential economic advantages with respect to dosing, acquisition cost and adverse effects as well as potential for overuse of this class of agents. Nevertheless, the new fluoroquinolones offer a useful addition to our current armamentarium of antibiotics for the institutional and community management of infections.

ACKNOWLEDGEMENTS: Dr Vercaigne is supported by a Glaxo Wellcome Infectious Diseases Fellowship. Dr Karlowsky is supported by a Medical Research Council/Pharmaceutical Manufacturers' Association of Canada fellowship. Dr Zhanel is the Merck Frosst Chair in Pharmaceutical Microbiology.

16. Bryskier A, Chantot JF. Classification and structure-activity relationships of fluoroquinolones. Drugs 1995;49(Suppl 2):16-28.

17. Mizuki Y, Fujiwara I, Yamaguchi T. Pharmacokinetic interactions related to the chemical structures of fluoroquinolones. J Antimicrob Chemother 1996;37(Suppl A):41-55.

18. Deppermann KM, Lode H. Fluoroquinolones: interaction profile during enteral absorption. Drugs 1993;45(Suppl 3):65-72.

19. Tanaka M, Kurata T, Fujisawa C, et al. Mechanistic study of inhibition of levofloxacin absorption by aluminum hydroxide. Antimicrob Agents Chemother 1993;37:2173-8.

20. Bryan LE, Bedard J, Wong S, Chamberland S. Quinolone antimicrobial agents: mechanism of action and resistance development. Clin Invest Med 1989;12:14-9.

21. Hooper DC. Quinolone mode of action. Drugs 1995;49(Suppl 2):10-5

22. Wolfson JS, Hooper DC. Fluoroquinolone antimicrobial agents. Clin Microbiol Rev 1989;2:378-424.

23. Hoshino K, Kitamura A, Morrissey I, Sato K, Kato JI, Ikeda H. Comparison of inhibition of Escherichia coli topoisomerase IV by quinolones with DNA gyrase inhibition. Antimicrob Agents Chemother 1994;38:2623-7.

24. Peng H, Marians KJ. Escherichia coli topoisomerase IV. J Biol Chem 1993;268:24481-90.

25. Kato JI, Nishimura Y, Imamura R, Niki H, Hiraga S, Suzuki H. New topoisomerase essential for chromosome segregation in E coli. Cell 1990;63:393-404.

26. Gootz TD, Zaniewski R, Haskell S, et al. Activity of the new fluoroquinolone trovafloxacin (CP-99,219) against DNA gyrase and topoisomerase IV mutants of Streptococcus pneumoniae selected in vitro. Antimicrob Agents Chemother 1996;40:2691-7.

27. Ferrero L, Cameron B, Crouzet J. Analysis of gyrA and grlA mutations in stepwise-selected ciprofloxacin-resistant mutants of Staphylococcus aureus. Antimicrob Agents Chemother 1995;39:1554-8.

28. Janoir C, Zeller V, Kitzis MD, Moreau NJ, Gutmann L. High-level fluoroquinolone resistance in Streptococcus pneumoniae requires mutations in parC and gyrA. Antimicrob Agents Chemother 1996;40:2760-4. 
29. Pan XS, Fisher LM. Targeting of DNA gyrase in Streptococcus pneumoniae by sparfloxacin: selective targeting of gyrase or topoisomerase IV by quinolones. Antimicrob Agents Chemother 1997:41:471-4.

30. Heisig P. Genetic evidence for a role of parC mutations in development of high-level fluoroquinolone resistance in Escherichia coli. Antimicrob Agents Chemother 1996;40:879-85.

31. Yoshida H, Bogaki M, Nakamura M, Yamanaka LM, Nakamura S. Quinolone resistance-determining region in the DNA gyrase gyrB gene of Escherichia coli. Antimicrob Agents Chemother 1991;35:1647-50.

32. Piddock LJV. Mechanisms of resistance to fluoroquinolones: state-of-the-art 1992-1994. Drugs 1995;49(Suppl 2):29-35.

33. Hooper DC, Wolfson JS, Souza KS, Tung C, McHugh GL, Swartz MN. Genetic and biochemical characterization of norfloxacin resistance in Escherichia coli. Antimicrob Agents Chemother 1986;29:639-44.

34. Nakanishi N, Yoshida S, Wakebe H, Inoue M, Yamaguchi T, Mitsuhashi S. Mechanisms of clinical resistance to fluoroquinolones in Staphylococcus aureus. Antimicrob Agents Chemother 1991;35:2562-7.

35. Kaatz GW, Seo SM, Ruble CA. Efflux-mediated fluoroquinolone resistance in Staphylococcus aureus. Antimicrob Agents Chemother 1993;37:1086-94.

36. Ng EYW, Trucksis M, Hooper DC. Quinolone resistance mediated by norA: physiologic characterization and relationship to flqB, a quinolone resistance locus on the Staphylococcus aureus chromosome. Antimicrob Agents Chemother 1994;38:1345-55.

37. Li XZ, Livermore DM, Nikaido H. Role of efflux pump(s) in intrinsic resistance of Pseudomonas aeruginosa: resistance to tetracycline, chloramphenicol and norfloxacin. Antimicrob Agents Chemother 1994;38:1732-41.

38. Deguchi T, Yasuda M, Nakano M, et al. Comparison of in vitro antimicrobial activity of AM-1155 with those of tosufloxacin and fleroxacin against clinical isolates of Neisseria gonorrhoeae harboring quinolone resistance alterations in gyrA and parC. Chemotherapy 1997;43:239-44.

39. Barry AL, Fuchs PC, Brown SD. In vitro activities of five fluoroquinolone compounds against strains of Streptococcus pneumoniae with resistance to other antimicrobial agents. Antimicrob Agents Chemother 1996;40:2431-3.

40. Fukuda H, Hiramatsu K. Primary targets of fluoroquinolones in Streptococcus pneumoniae. Antimicrob Agents Chemother 1999;43:410-2.

41. Jorgensen JH, Weigel LM, Ferraro MJ, Swenson JM, Tenover FC. Activities of newer fluoroquinolones against Streptococcus pneumoniae clinical isolates including those with mutations in the gyrA, parC and parE loci. Antimicrob Agents Chemother 1999;43:329-34.

42. National Committee for Clinical Laboratory Standards (NCCLS) Performance Standards For Antimicrobial Susceptibility Testing: 8th Informational Supplement. Villanova: NCCLS, 1998.

43. Brueggemann AB, Kugler KC, Doern GV. In vitro activity of BAY 12-8039, a novel 8-methoxyquinolone, compared to activities of six fluoroquinolones against Streptococcus pneumoniae, Haemophilus influenzae, and Moraxella catarrhalis. Antimicrob Agents Chemother 1997;41:1594-7.

44. Rolston KVI, Ho DH, Leblanc B, Streeter H, Dvorak T. In-vitro activity of trovafloxacin against clinical bacterial isolates from patients with cancer. J Antimicrob Chemother 1997;39(Suppl B):15-22.

45. Felmingham D, Robbins MJ, Ingley K, et al. In-vitro activity of trovafloxacin, a new fluoroquinolone, against recent clinical isolates. J Antimicrob Chemother 1997;39(Suppl B):43-9.

46. Marco F, Jones RN, Hoban DJ, Pignatari AC, Yamane N, Frei R. In-vitro activity of OPC-17116 against more than 6000 consecutive clinical isolates: a multicentre international study. J Antimicrob Chemother 1994;33:647-54.

47. Fuchs PC, Barry AL, Brown SD, Sewell DL. In vitro activity and selection of disk content for disk diffusion susceptibility tests with trovafloxacin. Eur J Clin Microbiol Infect Dis 1996;15:678-82.

48. Biedenbach DJ, Jones RN. The comparative antimicrobial activity of levofloxacin tested against 350 clinical isolates of streptococci. Diagn Microbiol Infect Dis 1996;25:47-51.

49. Thomson KS, Chartrand SA, Sanders CC, Block SL. Trovafloxacin, a new fluoroquinolone with potent activity against Streptococcus pneumoniae. Antimicrob Agents Chemother 1997;41:478-80.

50. Flamm RK, Vojtko C, Chu DTW, et al. In vitro evaluation of ABT-719, a novel DNA gyrase inhibitor. Antimicrob Agents Chemother 1995;39:964-70.

51. Schouten MA, Hoogkamp-Korstanje JAA. Comparative in-vitro activities of quinupristin-dalfopristin against Gram-positive bloodstream isolates. J Antimicrob Chemother 1997;40:213-9.

52. Cohen MA, Huband MD, Mailloux GB, Yoder SL, Roland GE, Heifetz CL. In vitro antibacterial activities of the fluoroquinolones PD 117596, PD124816, and PD 127391. Diagn Microbiol Infect Dis 1991;14:245-58.

53. Shonekan D, Handwerger S, Mildvan D. Comparative in-vitro activities of RP59500 (quinupristin/dalfopristin), CL 329,998, CL 331,002, trovafloxacin, clinafloxacin, teicoplanin and vancomycin against Gram-positive bacteria. J Antimicrob Chemother 1997;39:405-9.

54. Bauernfeind A. Comparative in-vitro activities of the new quinolone, Bay y 3118 , and ciprofloxacin, sparfloxacin, tosufloxacin, CI-960 and CI-990. J Antimicrob Chemother 1993;31:505-22.

55. Michelet C, Avril JL, Arvieux C, Jacquelinet C, Vu N, Cartier F. Comparative activities of new fluoroquinolones, alone or in combination with amoxicillin, trimethoprim-sulfamethoxazole, or rifampin, against intracellular Listeria monocytogenes. Antimicrob Agents Chemother 1997;41:60-5.

56. Hosaka M, Yasue T, Fukuda H, Tomizawa H, Aoyama H, Hirai K. In vitro and in vivo antibacterial activities of AM-1155, a new 6-fluoro-8-methoxy quinolone. Antimicrob Agents Chemother 1992;36:2108-17.

57. Wise R, Brenwald NP, Andrews JM, Boswell F. The activity of the methylpiperazinyl fluoroquinolone CG 5501: a comparison with other fluoroquinolones. J Antimicrob Chemother 1997;39:447-52.

58. Wakabayashi $\mathrm{E}$, Mitsuhashi S. In vitro antibacterial activity of AM-1155, a novel 6-fluoro-8-methoxy quinolone. Antimicrob Agents Chemother 1994;38:594-601.

59. Sader HS, Erwin ME, Jones RN. In vitro activity of OPC-17116 compared to other broad-spectrum fluoroquinolones. Eur J Clin Microbiol Infect Dis 1992;11:372-81.

60. Wiedemann B, Heisig P. Antibacterial activity of grepafloxacin. J Antimicrob Chemother 1997;40(Suppl A):19-25.

61. Wise R, Andrews JM. The activity of grepafloxacin against respiratory pathogens in the UK. J Antimicrob Chemother 1997;40(Suppl A):27-30.

62. Pankuch GA, Jacobs MR, Appelbaum PC. Activity of CP 99,219 compared with DU-6859a, ciprofloxacin, ofloxacin, levofloxacin, lomefloxacin, tosufloxacin, sparfloxacin and grepafloxacin against penicillin-susceptible and -resistant pneumococci. J Antimicrob Chemother 1995;35:230-2. (Lett)

63. Cormican MG, Jones RN. Antimicrobial activity and spectrum of LB20304, a novel fluoronaphthyridone. Antimicrob Agents Chemother 1997;41:204-11.

64. Biedenbach DJ, Jones RN. In vitro evaluation of DV-7751a, a new fluoroquinolone with an enhanced spectrum of activity against Gram-positive aerobic organisms and anaerobes. Antimicrob Agents Chemother 1995;39:1636-43.

65. Eliopoulos GM, Wennersten CB, Moellering RC Jr. Comparative in vitro activity of levofloxacin and ofloxacin against Gram-positive bacteria. Diagn Microbiol Infect Dis 1996;25:35-41.

66. Johnson AP, Speller DCE, Warner M, Domingue G. In-vitro activity of levofloxacin (1-ofloxacin) and ciprofloxacin against clinical isolates of Streptococcus pneumoniae obtained in England and Wales. J Antimicrob Chemother 1996;38:907-8. (Lett)

67. Takahashi Y, Masuda N, Otsuki M, Miki M, Nishino T. In vitro activity of HSR-903, a new quinolone. Antimicrob Agents Chemother 1997;41:1326-30.

68. Fass RJ. In vitro activity of Bay 12-8039, a new 8-methoxyquinolone. Antimicrob Agents Chemother 1997;41:1818-24.

69. Woodcock JM, Andrews JM, Boswell FJ, Brenwald NP, Wise R. In vitro activity of BAY 12-8039, a new fluoroquinolone. Antimicrob Agents Chemother 1997;41:101-6.

70. Felmingham D, Robbins MJ, Leakey A, et al. In vitro activity of BAY 12-8039. Eighth European Congress of Clinical Microbiology 
and Infectious Diseases. May 25-28, 1997. Lausanne: Bayer, 1997:9. (Poster P1156)

71. Hoogkamp-Korstanje JAA. Activity of BAY 12-8039 against aerobic and anaerobic Gram-positive rods. Eighth European Congress of Clinical Microbiology and Infectious Diseases. May 25-28, 1997. Lausanne: Bayer, 1997:7. (Poster \#P1154)

72. Endtz HP, Mouton JW, Den Hollander JG, Van Den Braak N, Verbrugh HA. Comparative in vitro activities of trovafloxacin (CP-99,219) against 445 Gram-positive isolates from patients with endocarditis, and those with other bloodstream infections. Antimicrob Agents Chemother 1997;41:1146-9.

73. Hoogkamp-Korstanje JAA, Dirks-Go SIS, Kabel P, et al. Multicentre in-vitro evaluation of the susceptibility of Streptococcus pneumoniae, Haemophilus influenzae and Moraxella catarrhalis to ciprofloxacin, clarithromycin, co-amoxiclav and sparfloxacin. J Antimicrob Chemother 1997;39:411-4.

74. Crokaert F, Aoun M, Duchateau V, Grenier P, Vandermies A, Klastersky J. In vitro activity of trovafloxacin (CP-99,219), sparfloxacin, ciprofloxacin, and fleroxacin against respiratory pathogens. Eur J Clin Microbiol Infect Dis 1996;15:696-8. (Lett)

75. Cohen MA, Yoder SL, Talbot GH. Sparfloxacin worldwide in vitro literature: isolate data available through 1994. Diagn Microbiol Infect Dis 1996;25:53-64.

76. Cunha BA, Qadri SMH, Ueno Y, Walters EA, Domenico P. Antibacterial activity of trovafloxacin against nosocomial Gram-positive and Gram-negative isolates. J Antimicrob Chemother 1997;39(Suppl B):29-34.

77. Dembry LM, Farrel PA, Orcutt DR, Gerrity LA, Andriole VT. In-vitro activity of trovafloxacin against sensitive and resistant aerobic bacteria using the standard microdilution broth method and Etest. J Antimicrob Chemother 1997;39(Suppl B):35-42.

78. Klugman KP, Gootz TD. In-vitro and in-vivo activity of trovafloxacin against Streptococcus pneumoniae. J Antimicrob Chemother 1997;39(Suppl B):51-5.

79. Sefton AM, Maskell JP, Rafay AM, Whiley A, Williams JD. The in-vitro activity of trovafloxacin, a new fluoroquinolone, against Gram-positive bacteria. J Antimicrob Chemother 1997;39(Suppl B):57-62.

80. Verbist L, Verhaegen J. In vitro activity of trovafloxacin versus ciprofloxacin against clinical isolates. Eur J Clin Microbiol Infect Dis 1996;15:683-5.

81. Visalli MA, Bajaksouzian S, Jacobs MR, Appelbaum PC. Comparative activity of trovafloxacin, alone and in combination with other agents, against Gram-negative nonfermentative rods. Antimicrob Agents Chemother 1997;41:1475-81.

82. Qadri SMH, Abo-Askar H, Ueno Y. Antibacterial activity of the new quinolone CI-960 (PD 127391) against clinical isolates at a major tertiary care center in Saudi Arabia. Chemotherapy 1992;38:92-8.

83. Citron DM, Appleman MD. Comparative in vitro activities of trovafloxacin (CP-99,219) against 221 aerobic and 217 anaerobic bacteria isolated form patients with intra-abdominal infections. Antimicrob Agents Chemother 1997;41:2312-6.

84. Tanaka M, Hoshino K, Ishida H, Sato K, Hayakawa I, Osada Y. Antimicrobial activity of DV-7751a, a new fluoroquinolone. Antimicrob Agents Chemother 1993;37:2112-8.

85. National Committee for Clinical Laboratory Standards (NCCLS) Methods For Antimicrobial Testing of Anaerobic Bacteria: approved standard M11-A4. Villanova: NCCLS, 1997.

86. Aldridge KE, Ashcraft $\mathrm{D}$, Bowman KA. Comparative in vitro activities of trovafloxacin (CP 99,219) and other antimicrobials against clinically significant anaerobes. Antimicrob Agents Chemother 1997;41:484-7.

87. Wexler HM, Molitoris E, Molitoris D, Finegold SM. In vitro activities of trovafloxacin against 557 strains of anaerobic bacteria. Antimicrob Agents Chemother 1996;40:2232-5.

88. Nord CE. In vitro activity of quinolones and other antimicrobial agents against anaerobic bacteria. Clin Infect Dis 1996;23(Suppl 1):S15-8.

89. Spangler SK, Jacobs MR, Appelbaum PC. Activity of CP 99,219 compared with those of ciprofloxacin, grepafloxacin, metronidazole, cefoxitin, piperacillin, and piperacillintazobactam against 489 anaerobes. Antimicrob Agents Chemother 1994;38:2471-6.
90. Aldridge KE, Ashcraft DS. Comparison of the in vitro activities of Bay 12-8039, a new quinolone, and other antimicrobials against clinically important anaerobes. Antimicrob Agents Chemother 1997;41:709-11.

91. Goldstein EJC, Citron DM. Comparative activity of ciprofloxacin, ofloxacin, sparfloxacin, temafloxacin, CI-960, CI-990, and WIN 57273 against anaerobic bacteria. Antimicrob Agents Chemother 1992;36:1158-62.

92. Appelbaum PC. Quinolone activity against anaerobes: microbiological aspects. Drugs 1995;49(Suppl 2):76-80.

93. Hecht DW, Wexler HM. In vitro susceptibility of anaerobes to quinolones in the United States. Clin Infect Dis 1996;23(Suppl 1):S2-8.

94. Kato N, Kato H, Tanaka-Bando K, Watanabe K, Ueno K. Comparison of in vitro activities of DU-6859a and other fluoroquinolones against Japanese isolates of anaerobic bacteria. Clin Infect Dis 1996;23(Suppl 1):S31-5.

95. Nord CE, Edlund C. Susceptibility of anaerobic bacteria to BAY 12-8039, a new methoxyquinolone. Eighth European Congress of Clinical Microbiology and Infectious Diseases. May 25-28, 1997. Lausanne: Bayer, 1997:10. (Poster P1154)

96. Dubois J, St-Pierre C. An in vitro susceptibility study of trovafloxacin against Legionella species. In: Trovafloxacin: A Review of Publications and Congress Presentations. West Sussex: Cambridge Medical Publications, 1997:70-1.

97. Miyashita N, Niki Y, Kishimoto T, Nakajima M, Matsushima T. In vitro and in vivo activities of AM-1155, a new fluoroquinolone, against Chlamydia spp. Antimicrob Agents Chemother 1997;41:1331-4.

98. Waites KB, Duffy LB, Schmid T, Crabb D, Pate MS, Cassell GH. In vitro susceptibilities of Mycoplasma pneumoniae, Mycoplasma hominis, and Ureaplasma urealyticum to sparfloxacin and PD 127391. Antimicrob Agents Chemother 1991;35:1181-5.

99. Gooding BB, Erwin ME, Barrett MS, Johnson DM, Jones RN. Antimicrobial activities of two investigational fluoroquinolones (CI-960 and E4695) against over 100 Legionella sp isolates. Antimicrob Agents Chemother 1992;36:2049-50.

100. Ullmann U, Shubert S, Krausse R. In vitro activity of gatifloxacin, other fluoroquinolones, doxycyclin and erythromycin against Ureaplasma urealyticum and Mycoplasma hominis. Second European Congress of Chemotherapy and the Seventh Biennial Conference on Anti-Infective Agents and Chemotherapy. June 25-27, 1998. Hamburg: Grunenthal, 1998. (Abst 2)

101. Ridgway GL, Salman H, Robbins MJ, Dencer C, Felmingham D. The in-vitro activity of grepafloxacin against Chlamydia spp, Mycoplasma spp., Ureaplasma urealyticum and Legionella spp. J Antimicrob Chemother 1997;40(Suppl A):31-4.

102. Edelstein PH, Edelstein MAC, Lehr KH, Ren J. In-vitro activity of levofloxacin against clinical isolates of Legionella spp, its pharmacokinetics in guinea pigs, and use in experimental Legionella pneumophila pneumonia. J Antimicrob Chemother 1996;37:117-26.

103. Kaku M, Ishida $\mathrm{K}$, Irifune $\mathrm{K}$, et al. In vitro and in vivo activities of sparfloxacin against Mycoplasma pneumoniae. Antimicrob Agents Chemother 1994;38:738-41.

104. Renaudin $\mathrm{H}$, Bebear CM, Boudjadja A, Bebear C. In vitro activity of BAY 12-8039, a new 8-methoxyquinolone, against mycoplasmas. Thirty-sixth Interscience Conference on Antimicrobial Agents and Chemotherapy. New Orleans, September 18-20, 1996. (Abst 6009)

105. Roblin PM, Hammerschlag MR. Activity of BAY 12-8039, a new 8-methoxyquinolone, against Chlamydia pneumoniae in vitro. Thirty-sixth Interscience Conference on Antimicrobial Agents and Chemotherapy. New Orleans, September 18-20, 1996. (Abst F011)

106. Roblin PM, Kutlin A, Hammerschlag MR. In vitro activity of trovafloxacin against Chlamydia pneumoniae. Antimicrob Agents Chemother 1997;41:2033-4.

107. Kenny GE, Cartwright FD. Susceptibilities of Mycoplasma pneumoniae, Mycoplasma hominis, and Ureaplasma urealyticum to a new quinolone, trovafloxacin (CP-99,219). Antimicrob Agents Chemother 1996;40:1048-9.

108. Vance-Bryan K, Guay DRP, Rotschafer JC. Clinical 
pharmacokinetics of ciprofloxacin. Clin Pharmacokinet 1990;19:434-61.

109. Bron NJ, Dorr MB, Mant TG, Webb CL, Vassos AB. The tolerance and pharmacokinetics of clinafloxacin. J Antimicrob Chemother 1996;38:1023-9.

110. Stein GE. Pharmacokinetics and pharmacodynamics of newer fluoroquinolones. Clin Infect Dis 1996;23(Suppl 1):S19-24.

111. Nakashima M, Uematsu T, Kosuge K, et al. Single- and multiple-dose pharmacokinetics of AM-1155, a new 6-fluoro-8-methoxy quinolone, in humans. Antimicrob Agents Chemother 1995;39:2635-40.

112. Efthymiopoulos C, Bramer SL, Maroli A. Pharmacokinetics of grepafloxacin after oral administration of single and repeat doses in healthy young males. Clin Pharmacokinet 1997;33(Suppl 1):1-8.

113. Kozawa O, Uematsu T, Matsuno H, Niwa M, Nagashima S, Kanamaru M. Comparative study of pharmacokinetics of two new fluoroquinolones, balofloxacin and grepafloxacin, in elderly subjects. Antimicrob Agents Chemother 1996;40:2824-8.

114. Uematsu T, Nagashima S, Takiguchi Y, Nakashima M. OPC-17116, a new quinolone: phase I study. Thirty-first Interscience Conference on Antimicrobial Agents and Chemotherapy. Chicago, September 29 to October 2, 1991. (Abst 1481)

115. Koike M, Nii S, Morita S, Akiyama H, Odomi M. OPC-17116, a new quinolone: pharmacokinetics and metabolism in healthy volunteers. Thirty-first Interscience Conference on Antimicrobial Agents and Chemotherapy. Chicago, September 29 to October 2, 1991. (Abst 1482).

116. Efthymiopoulos C, Bramer SL, Maroli A. Effect of renal impairment on the pharmacokinetics of grepafloxacin. Clin Pharmacokinet 1997;33(Suppl 1):32-8.

117. Efthymiopoulos C, Bramer SL, Maroli A, et al. Grepafloxacin pharmacokinetics in individuals with hepatic dysfunction. Clin Pharmacokinet 1997;33(Suppl 1):25-31.

118. Chien SC, Chow AT, Natarajan J, et al. Absence of age and gender effects on the pharmacokinetics of a single 500-milligram oral dose of levofloxacin in healthy subjects. Antimicrob Agents Chemother 1997;41:1562-5.

119. Chien SC, Rogge MC, Gisclon LG, et al. Pharmacokinetic profile of levofloxacin following once-daily 500-milligram oral or intravenous doses. Antimicrob Agents Chemother 1997;41:2256-60.

120. Fish DN, Chow AT. The clinical pharmacokinetics of levofloxacin. Clin Pharmacokinet 1997;32:101-19.

121. Goodwin SD, Gallis HA, Chow AT, Wong FA, Flor SC, Bartlett JA. Pharmacokinetics and safety of levofloxacin in patients with human immunodeficiency virus infection. Antimicrob Agents Chemother 1994;38:799-804.

122. Chien SC, Chow AT, Fowler C, et al. Double-blind evaluation of the safety and pharmacokinetics of multiple oral once-daily $750 \mathrm{mg}$ and $1 \mathrm{~g}$ doses of levofloxacin in healthy volunteers. Thirty-sixth Interscience Conference on Antimicrobial Agents and Chemotherapy. New Orleans, September 18-20, 1996. (Abst A14).

123. Gisclon LG, Curtin CR, Chien SC, Williams R, Corrado M, Reichl V. The pharmacokinetics of levofloxacin in subjects with renal impairment, and in subjects receiving hemodialysis or continuous ambulatory peritoneal dialysis. Thirty-sixth Interscience Conference on Antimicrobial Agents and Chemotherapy. New Orleans, September 18-20, 1996. (Abst A13)

124. Levofloxacin Product Monograph. Toronto: Janssen-Ortho, 1998.

125. Stass HH, Dalhoff A, Kubitza D, Ahr G. BAY 12-8039, a new 8-methoxy-quinolone: first pharmacokinetic results in healthy male volunteers. Thirty-sixth Interscience Conference on Antimicrobial Agents and Chemotherapy. New Orleans, September 18-20, 1996. (Abst F24)

126. Kubitza D, Stass HH, Wingender W, Kuhlmann J. BAY 12-8039, a new 8-methoxy-quinolone: safety, tolerability, and steady state pharmacokinetics in healthy male volunteers. Thirty-sixth Interscience Conference on Antimicrobial Agents and Chemotherapy. New Orleans, September 18-20, 1996. (Abst F25)

127. Stab H, Dalhoff A, Kubitza D. BAY 12-8039: study on the food effect after oral administration of $200 \mathrm{mg}$ SD to healthy volunteers. Eighth European Congress of Clinical Microbiology and Infectious Diseases. May 25-28, 1997. Lausanne: Bayer, 1997:1. (Poster P386)
128. Montay G, Bruno R, Vergniol JC, et al. Pharmacokinetics of sparfloxacin in humans after single oral administration at doses of 200, 400, 600, and $800 \mathrm{mg}$. J Clin Pharmacol 1994;34:1071-6.

129. Zix JA, Geerdes-Fenge HF, Rau M, et al. Pharmacokinetics of sparfloxacin and interaction with cisapride and sucralfate. Antimicrob Agents Chemother 1997;41:1668-72.

130. Fillastre JP, Montay G, Bruno R, et al. Pharmacokinetics of sparfloxacin in patients with renal impairment. Antimicrob Agents Chemother 1994;38:733-7.

131. Ritz M, Lode H, Fabbender M, Borner K, Koeppe P, Nord CE. Multiple-dose pharmacokinetics of sparfloxacin and its influence on fecal flora. Antimicrob Agents Chemother 1994;38:455-9.

132. Montay G. Pharmacokinetics of sparfloxacin in healthy volunteers and patients: a review. J Antimicrob Chemother 1996;37(Suppl A):27-39.

133. Johnson R, Geary W, Jensen B. The absolute oral bioavailability of sparfloxacin in healthy male subjects.Thirty-sixth Interscience Conference on Antimicrobial Agents and Chemotherapy. New Orleans, September 18-20, 1996. (Abst A9)

134. Mugnier P, Taburet AM, Wyld PJ, et al. Pharmacokinetics of sparfloxacin in patients with hepatic failure. Thirty-fourth Interscience Conference on Antimicrobial Agents and Chemotherapy. Washington, DC, October 4-7, 1994. (Abst A45)

135. Vincent J, Venitz J, Teng R, et al. Pharmacokinetics and safety of trovafloxacin in healthy male volunteers following administration of single intravenous doses of the prodrug, alatrofloxacin. J Antimicrob Chemother 1997;39(Suppl B):75-80.

136. Teng R, Liston TE, Harris SC. Multiple-dose pharmacokinetics and safety of trovafloxacin in healthy volunteers. J Antimicrob Chemother 1996;37:955-63.

137. Teng R, Dogolo L, Willavize SA, Friedman HL, Vincent J. Oral bioavailability of trovafloxacin with and without food in health volunteers. J Antimicrob Chemother 1997;39(Suppl B):87-92.

138. Teng R, Harris SC, Nix DE, Schentag JJ, Foulds G, Liston TE. Pharmacokinetics and safety of trovafloxacin (CP-99,219), a new quinolone antibiotic, following administration of single oral doses to healthy male volunteers. J Antimicrob Chemother 1995;36:385-94.

139. Taylor A, Swan S, Marbury T, et al. The effect of varying degrees of renal impairment on the safety, toleration and pharmacokinetics of trovafloxacin. Thirty-seventh Interscience Conference on Antimicrobial Agents and Chemotherapy. Toronto, September 28 to October 1, 1997. (Abst A-66)

140. Anderson KE, Egger NG, Goeger DE, et al. The safety, toleration and pharmacokinetics of trovafloxacin in patients with hepatic impairment. Thirty-seventh Interscience Conference on Antimicrobial Agents and Chemotherapy. Toronto, September 28 to October 1, 1997. (Abst A-65)

141. Wilson APR, Gruneberg RN. Ciprofloxacin: 10 years of clinical experience. Somerset: Maxim Medical, 1997:67.

142. Trovafloxacin. Med Lett Drug Ther 1998;40(1022):30-1.

143. Tack KJ, McGuire NM, Eiseman IA. Initial clinical experience with clinafloxacin in the treatment of serious infections. Drugs 1995;49(Suppl 2):488-91.

144. Goehler K, Stahlberg HJ, Guillaume M, Mignot A. Safety, tolerance and food effect after single and multiple oral doses of gatifloxacin, a new fluoroquinolone antibiotic, to healthy caucasian volunteers. Second European Congress of Chemotherapy and the Seventh Biennial Conference on Anti-Infective Agents and Chemotherapy. Hamburg, June 25-27, 1998. (Poster)

145. Efthymiopoulos C, Bramer SL, Maroli A. Effect of food and gastric $\mathrm{pH}$ on the bioavailability of grepafloxacin. Clin Pharmacokinet 1997;33(Suppl 1):18-24.

146. Thebault JJ, Montay G, Ebmeier M, et al. Effect of food on the bioavailability of the new quinolone RP-64206. Thirtieth Interscience Conference on Antimicrobial Agents and Chemotherapy. Atlanta, October 21 to 24, 1990. (Abst 1249)

147. Johnson JH, Cooper MA, Andrews JM, Wise R. Pharmacokinetics and inflammatory fluid penetration of sparfloxacin. Antimicrob Agents Chemother 1992;36:2444-6.

148. Wise R, Honeybourne D. A review of the penetration of sparfloxacin into the lower respiratory tract and sinuses. J Antimicrob Chemother 1996;37(Suppl A):57-63.

149. Tanimura H, Uchiyama K, Kashiwagi H. Gallbladder tissue 
concentrations, biliary excretion and pharmcokinetics of OPC-17116. Drugs 1995;49(Suppl 2):341-3. (Abst)

150. Child J, Andrews JM, Wise R. Pharmacokinetics and tissue penetration of the new fluoroquinolone grepafloxacin. Antimicrob Agents Chemother 1995;39:513-5.

151. Takahashi Y, Itoh Y, Doi T, Kuriyama M, Kawada Y. Penetration of OPC-17116, a new quinolone compound, into male genital tracts and its in vitro antibacterial activity. Thirty-first Interscience Conference on Antimicrobial Agents and Chemotherapy. Chicago, September 29 to October 2, 1991. (Abst 1486)

152. Suzuki K, Horiba M. Penetration of OPC-17116, a new quinolone derivative, into human prostatic fluid. Thirty-first Interscience Conference on Antimicrobial Agents and Chemotherapy. Chicago, September 29 to October 2, 1991. (Abst 1487)

153. Cook PJ, Andrews JM, Wise R, Honeybourne D, Moudgil H. Concentrations of OPC-17116, a new fluoroquinolone antibacterial, in serum and lung compartments. J Antimicrob Chemother 1995;35:317-26.

154. Ohnishi $\mathrm{H}$, Tanimura $\mathrm{H}$, Ichimiya $\mathrm{G}$ et al. Excretion of levofloxacin into bile and gallbladder tissue. Drugs 1993;45(Suppl 3):260-1. (Abst)

155. Child J, Mortiboy D, Andrews JM, Chow AT, Wise R. Open-label crossover study to determine pharmacokinetics and penetration of two dose regimens of levofloxacin into inflammatory fluid. Antimicrob Agents Chemother 1995;39:2749-51.

156. Shimada J, Nogita T, Ishibashi Y. Clinical pharmacokinetics of sparfloxacin. Clin Pharmacokinet 1993;25:358-69.

157. Cutler NR, Vincent J, Jhee SS, et al. Penetration of tovafloxacin into cerebrospinal fluid in humans following intravenous infusion of alatrofloxacin. Antimicrob Agents Chemother 1997;41:1298-300.

158. Wise R, Mortiboy D, Child J, Andrews JM. Pharmacokinetics and penetration into inflammatory fluid of trovafloxacin (CP-99,219). Antimicrob Agents Chemother 1996;4047-9.

159. Childs S, Gleason D, Immergut M, et al. Penetration of trovafloxacin into prostatic tissue following multiple dosing in man. Thirty-seventh Interscience Conference on Antimicrobial Agents and Chemotherapy. Toronto, September 28 to October 1, 1997. (Abst A-67)

160. Andrews JM, Honeybourne D, Brenwald NP, et al. Concentrations of trovafloxacin in bronchial mucosa, epithelial lining fluid, alveolar macrophages and serum after administration of single or multiple oral doses to patients undergoing fibre-optic bronchoscopy. J Antimicrob Chemother 1997;39:797-802

161. Lode H. Clinafloxacin vs ceftazidime study demographic summary. Second European Congress of Chemotherapy and the Seventh Biennial Conference on Anti-Infective Agents and Chemotherapy. Hamburg, June 25-27, 1998.

162. Chodosh S, Lakshminarayan S, Swarz H, Breisch S. Efficacy and safety of a 10-day course of 400 or 600 milligrams of grepafloxacin once daily for treatment of acute bacterial exacerbations of chronic bronchitis: comparison with a 10-day course of 500 milligrams of ciprofloxacin twice daily. Antimicrob Agents Chemother 1998;42:114-20.

163. Langan CE, Cranfield R, Breisch S, Pettit R. Randomized, double-blind study of grepafloxacin versus amoxycillin in patients with acute bacterial exacerbations of chronic bronchitis. J Antimicrob Chemother 1997;40(Suppl A):63-72.

164. Kobayashi H. A multicenter, double-blind comparative study of grepafloxacin (GPFX) versus ofloxacin in the treatment of chronic tract respiratory infection. Thirty-sixth Interscience Conference on Antimicrobial Agents and Chemotherapy. New Orleans, September 18-20, 1996. (Abst LM15)

165. O'Doherty B, Dutchman DA, Pettit R, Maroli A. Randomized, double-blind, comparative study of grepafloxacin and amoxycillin in the treatment of patients with community-acquired pneumonia. J Antimicrob Chemother 1997;40(Suppl A):73-81.

166. Patel T, Desai R, Duff J, Johnson ME, Briesch SA, Maroli AN. Comparison of grepafloxacin with clarithromycin in the treatment of community-acquired pneumonia. Thirty-seventh Interscience Conference on Antimicrobial Agents and Chemotherapy. Toronto, September 28 to October 1, 1997. (Abst LM-69)

167. Kobayashi H. A multicenter, double-blind comparative study of grepafloxacin versus ofloxacin in the treatment of pneumonia. Thirty-sixth Interscience Conference on Antimicrobial Agents and Chemotherapy. New Orleans, September 18-20, 1996. (Abst LM18)

168. DeAbate CA, Russell M, McElvaine P, et al. Safety and efficacy of oral levofloxacin versus cefuroxime axetil in acute bacterial exacerbations of chronic bronchitis. Respir Care 1997;42:206-13.

169. Shah PM, and members of the International Study Group. Levofloxacin vs cefuroxime axetil in the treatment of acute exacerbations of chronic bronchitis. Thirty-seventh Interscience Conference on Antimicrobial Agents and Chemotherapy. Toronto, September 28 to October 1, 1997. (Abst LM-38)

170. Habib MP, Gentry LO, Rodriguez-Gomez G, et al. Multicenter randomized study comparing efficacy and safety of oral levofloxacin and cefaclor in treatment of acute bacterial exacerbations of chronic bronchitis. Infect Dis Clin Pract 1998; $7: 101-9$

171. File JR TM, Segreti J, Dunbar L, et al. A multicenter, randomized study comparing the efficacy and safety of intravenous and/or oral levofloxacin versus ceftriaxone and/or cefuroxime axetil in treatment of adults with community-acquired pneumonia. Antimicrob Agents Chemother 1997;41:1965-72.

172. Carbon C, and members of the International Study Group. Comparative study of levofloxacin and Co-amoxiclav in the treatment of community-acquired pneumonia in adults. Thirty-seventh Interscience Conference on Antimicrobial Agents and Chemotherapy. Toronto, September 28 to October 1, 1997. (Abst LM70)

173. Shishido H, Furukawa K, Nagai H, Kawakami K, Kono H. Oral levofloxacin $600 \mathrm{mg}$ and $300 \mathrm{mg}$ daily doses in difficult-to-treat respiratory infections. Drugs 1995;49(Suppl 2):433-5. (Abst)

174. Nakamori Y, Miyashita Y, Nakatani I, Nakata K. Levofloxacin: penetration into sputum and once-daily treatment of respiratory tract infections. Drugs 1995;49(Suppl 2):418-9. (Abst)

175. Kawai T. Clinical evaluation of levofloxacin $200 \mathrm{mg} 3$ times daily in the treatment of bacterial lower respiratory tract infections. Drugs 1995;49(Suppl 2):416-7. (Abst)

176. Sato A, Ogawa H, Iwata M, et al. Clinical efficacy of levofloxacin in elderly patients with respiratory tract infections. Drugs 1995;49(Suppl 2):428-9. (Abst)

177. DeAbate CA, for the SPAR Multicentre ABECB Study Group. Treatment of acute bacterial exacerbations of chronic bronchitis with sparfloxacin and ofloxacin. Thirty-sixth Interscience Conference on Antimicrobial Agents and Chemotherapy. New Orleans, September 18-20, 1996. (Abst LM9)

178. Allegra L, Konietzko N, Leophonte $\mathrm{P}$, et al. Comparative safety and efficacy of sparfloxacin in the treatment of acute exacerbations of chronic obstructive pulmonary disease: a double-blind, randomised, parallel, multicentre study. J Antimicrob Chemother 1996;37(Suppl A):93-104.

179. Taytard A, Gil Aguado A, Vogel F. Short (5 days) course of sparfloxacin in the treatment of acute exacerbation of chronic bronchitis. First European Congress of Chemotherapy, 1996. May 14-17, 1996. (Abst W169)

180. Lode H, Garau J, Grassi C, et al. Treatment of community-acquired pneumonia: a randomized comparison of sparfloxacin, amoxycillin-clavulanic acid and erythromycin. Eur Respir J 1995;8:1999-2007.

181. Bensch G, for the SPAR Multicentre CAP Study Group. Treatment of community-acquired pneumonia with sparfloxacin and erythromycin. Thirty-sixth Interscience Conference on Antimicrobial Agents and Chemotherapy. New Orleans, September 18-20, 1996. (Abst LM12)

182. Donowitz Gfor the SPAR Multicentre CAP Study Group. Treatment of community acquired pneumonia with sparfloxacin and cefaclor. Thirty-sixth Interscience Conference on Antimicrobial Agents and Chemotherapy. New Orleans, September 18-20, 1996. (Abst LM10)

183. Ortqvist A, Valtonen M, Cars O, Wahl M, Saikku P, Jean C. Oral empiric treatment of community-acquired pneumonia. Chest 1996;110:1499-506.

184. Portier H, May TH, Proust A. Comparative efficacy of sparfloxacin in comparison with amoxycillin plus ofloxacin in the treatment of community-acquired pneumonia. J Antimicrob Chemother 1996;37(Suppl A):83-91. 
185. Aubier M, Verster R, Regamey C, Geslin P, Vercken JB. Once-daily sparfloxacin versus high-dosage amoxicillin in the treatment of community-acquired, suspected pneumococcal pneumonia in adults. Clin Infect Dis 1998;26:1312-20.

186. Niederman, M, Traub S, Ellison WT, Hopkins DW. A double-blind, randomized, multicenter, global study in hospitalized community-acquired pneumonia comparing trovafloxacin with ceftriaxone with or without erythromycin. Second European Congress of Chemotherapy. Hamburg, June 25-27, 1998. (Poster)

187. Sullivan J, Gezon J, Hopkins DW. A double blind, randomized, multicenter study in ambulatory community acquired pneumonia comparing trovafloxacin with clarithromycin. Thirty-seventh Interscience Conference on Antimicrobial Agents and Chemotherapy. Toronto, September 28 to October 1,1997. (Abst LM-73)

188. Mandell L, Hopkins DW, Hopkins S. Efficacy of trovafloxacin in patients with community acquired pneumonia due to penicillin susceptible and resistant $S$ pneumoniae. Thirty-seventh Interscience Conference on Antimicrobial Agents and Chemotherapy. Toronto, September 28 to October 1, 1997. (Abst LM-71)

189. Graham DR, Klein T, Torres A, Niedermann M. A double blind, randomized, multicenter study of nosocomial pneumonia comparing trovafloxacin with ciprofloxacin with or without clindamycin/metronidazole. Thirty-seventh Interscience Conference on Antimicrobial Agents and Chemotherapy. Toronto, September 28 to October 1, 1997. (Abst LM-74)

190. Suzuki K, Katoh S, Horiba M, Ishikawa K, Hoshinaga K, Naide Y. Gatifloxacin, a newer quinolone derivative in the treatment of chronic bacterial prostatitis. Second European Congress of Chemotherapy and the Seventh Biennial Conference on Anti-Infective Agents and Chemotherapy. Hamburg, June 25-27, 1998. (Poster)

191. Hook EW III, McCormack WM, Martin D, et al. Comparison of Single-dose oral grepafloxacin with cefixime for treatment of uncomplicated gonorrhea in men. Antimicrob Agents Chemother 1997;41:1843-5.

192. Matsuda S. A multicenter, double-blind comparative study of grepafloxacin versus ofloxacin in the treatment of obstetric and gynecological infection. Thirty-sixth Interscience Conference on Antimicrobial Agents and Chemotherapy. New Orleans, September 18-20, 1996. (Abst LM16)

193. Mroczkowski TF, Bean KA, Martin DH. A dose ranging study of a new quinolone, OPC-17116, for the treatment of Chlamydia trachomatis $(\mathrm{Ct})$ infection in women. Sex Transm Dis 1994;21(Suppl 2):S106-7. (Lett)

194. Mroczkowski TF, Martin DH, Bean KA, et al. OPC-17116 in the treatment of gonococcal and chlamydial cervicitis. J Eur Acad Dermetal Venercel 1995;(Suppl 1):577. (Abst 30)

195. Richard GA, Klimberg IN, Fowler C, Callery-D'Amico S. A combined analysis of two studies comparing levofloxacin with two other fluoroquinolones for the treatment of acute pyelonephritis. Thirty-sixth Interscience Conference on Antimicrobial Agents and Chemotherapy. New Orleans, September 18-20, 1996. (Abst LM3)

196. Klimberg IV, Cox CE II, Fowler CL, King W, Kim SS, Callery-D'Amico S. A controlled trial of levofloxacin and lomefloxacin in the treatment of complicated urinary tract infection. Urology 1998;51:610-5.

197. Suzuki K, Horiba M, Tanaka T, Naide Y, Yonetsu M. Levofloxacin in the treatment of chronic prostatitis. Drugs 1993;45(Suppl 3):368-9. (Abst)

198. Moi H, Morel P, Gianotti B, Barlow D, Phillips I, Jean C. Comparative efficacy and safety of single oral doses of sparfloxacin versus ciprofloxacin in the treatment of acute gonococcal urethritis in men. J Antimicrob Chemother 1996;37(Suppl A):115-22.

199. Phillips I, Dimian C, Barlow D, et al. A comparative study of two different regimens of sparfloxacin versus doxycycline in the treatment of non-gonococcal urethritis in men. J Antimicrob Chemother 1996;37(Suppl A):123-34.

200. Naber KG, Di Silverio F, Geddes A, Guibert J. Comparative efficacy of sparfloxacin versus ciprofloxacin in the treatment of complicated urinary tract infection. J Antimicrob Chemother 1996;37(Suppl A):135-44.
201. Iravani A, for the SPAR Multicentre UUTI Study Group. Treatment of community-acquired acute uncomplicated urinary tract infections with sparfloxacin and ciprofloxacin.Thirty-sixth Interscience Conference on Antimicrobial Agents and Chemotherapy. New Orleans, September 18-20, 1996. (Abst LM6)

202. Henry D, for the SPAR Multicentre UUTI Study Group. Treatment of community-acquired acute uncomplicated urinary tract infections with sparfloxacin and ofloxacin.Thirty-sixth Interscience Conference on Antimicrobial Agents and Chemotherapy. New Orleans, September 18-20, 1996. (Abst LM7)

203. Kawada Y, two other authors, et al. Sparfloxacin in the treatment of genitourinary tract infections. Drugs 1993;45(Suppl 3):339. (Abst)

204. Matsuda S, two other authors, et al. Clinical experience with sparfloxacin in the treatment of gynaecological infection. Drugs 1993;45(Suppl 3):384. (Abst)

205. Hook III EW, Pinson GB, Blalock CJ, Johnson RB. Dose-ranging study of CP-99,219 (trovafloxacin) for treatment of uncomplicated gonorrhea. Antimicrob Agents Chemother 1996;40:1720-1.

206. Jones RB, Schwebke J, Thorpe Jr EM, Dalu ZA, Leone P, Johnson RB. Randomized trial of trovafloxacin and ofloxacin for single-dose therapy of gonorrhea. Am J Med 1998;104:28-32.

207. Arata J, et al. A multicenter, double-blind comparative study of grepafloxacin versus ofloxacin in the treatment of skin and skin structure infections. Thirty-sixth Interscience Conference on Antimicrobial Agents and Chemotherapy. New Orleans, September 18-20, 1996. (Abst LM17)

208. Nicodemo AC, Robledo JA, Jasovich A, Neto W. A multicenter, double-blind, randomized study comparing the efficacy and safety of oral levofloxacin versus ciprofloxacin in the treatment of uncomplicated skin and skin structure infections. Int J Clin Pract 1998;52:69-74.

209. Nichols RL, Smith JW, Gentry LO, et al. Multicenter, randomized study comparing levofloxacin and ciprofloxacin for uncomplicated skin and skin structure infections. South Med J 1997;90:1192-200.

210. Lipsky BA, for the SPAR Multicentre SSSI Study Group. Treatment of community-acquired complicated skin and skin structure infections with sparfloxacin. Thirty-sixth Interscience Conference on Antimicrobial Agents and Chemotherapy. New Orleans, September 18-20, 1996. (Abst LM11)

211. Takahashi H, and the Japanese Collabotative Study Group of Sparfloxacin in dermatology. Sparfloxacin in the treatment of skin and soft tissue infections. Drugs 1993;45(Suppl 3):386. (Abst)

212. Watanabe T, Akieda Y, Suzuki T, Itokawa K, Yamaji E, Nakayama I. Clinical trials of a new quinolone, sparfloxacin, in skin and skin structure infections. Drugs 1993;45(Suppl 3):388-9. (Abst)

213. Wilson SE. Intra-abdominal infection trial: clinafloxacin vs. imipenem. Second European Congress of Chemotherapy and the Seventh Biennial Conference on Anti-Infective Agents and Chemotherapy. Hamburg, June 25-27, 1998.

214. Bartlett JG, Breiman RF, Mandell LA, File TM Jr. Community-acquired penumoniae in adults: guidelines for management. Clin Infect Dis 1998;26:811-38.

215. Wise R, Brenwald N, Gill M, Fraise A. Streptococcus pneumoniae resistance to fluoroquinolones. Lancet 1996;348:1660.

216. Goldstein EJC. Possible role for the new fluoroquinolones (levofloxacin, grepafloxacin, trovafloxacin, clinafloxacin, sparfloxacin, and DU-6859a) in the treatment of anaerobic infections: review of current information on efficacy and safety. Clin Infect Dis 1996;23(Suppl 1):S25-30.

217. Stahlmann R, Schwabe R. Safety profile of grepafloxacin compared with other fluoroquinolones. J Antimicrob Chemother 1997;40(Suppl A):83-92.

218. Grepafloxacin - a new fluoroquinolone. Med Lett Drug Ther 1998;40(1019):17-8.

219. Sullivan JT, Kubitza D, Schuhly U, Wingender W. Safety of the new quinolone BAY 12-8039 in 130 healthy volunteers. Twentieth International Congress of Chemotherapy. June 29 to July 3, 1997. Sydney: Bayer AG, 1997:16. (Abst)

220. Sullivan JT, Woodruff M, Lettieri J, Agarwal V, Krol G, Heller AH. 
Pharmacokinetics and tolerability of the new methoxyquinolone BAY 12-8039: 10 days' treatment at $400 \mathrm{mg}$ daily. Eighth European Congress of Clinical Microbiology and Infectious Diseases. May 25-28, 1998. Lausanne: Bayer, 1997. (Poster P389).

221. Rubinstein E. Safety profile of sparfloxacin in the treatment of respiratory tract infections. J Antimicrob Chemother 1996;37(Suppl A):145-60.

222. Jaillon P, Morganroth J, Brumpt I, Talbot G. Overview of electrocardiographic and cardiovascular safety data for sparfloxacin. J Antimicrob Chemother 1996;37(Suppl A):161-7.

223. Haria M, Lamb HM. Trovafloxacin. Drugs 1997;54:435-45.

224. Ferguson J, McEwen J, Patterson BE, Purkins L, Colman PJ, Willavize SA. An open, observer-blinded, placebo-controlled, randomized, parallel-group study to investigate the phototoxic potential of trovafloxacin, ciprofloxacin and lomefloxacin. In: Trovafloxacin: A Review of Publications and Congress Presentations. West Sussex: Cambridge Medical Publications, 1997:148-9. (Abst)

225. Dupont H, Timsit JF, Souweine B, Gachot B, Wolff M, Regnier B. Torsades de pointe probably related to sparfloxacin. Eur J Clin Microbiol Infect Dis 1996;15:350-1. (Lett)

226. Lietman PS. Fluoroquinolone toxicities: An update. Drugs 1995;49(Suppl 2):159-63.

227. Ferguson J, Dawe R. Phototoxicity in quinolones: comparison of ciprofloxacin and grepafloxacin. J Antimicrob Chemother 1997;40(Suppl A):93-8

228. Ball P, Tillotson G. Tolerability of fluoroquinolone antibiotics. Drug Saf 1995;13:343-58.

229. Stahlmann R, Forster C, Van Sickle D. Quinolones in children. Are concerns over arthropathy justified. Drug Saf 1993;9:397-403

230. Schaad UB. Role of the new quinolones in pediatric practice. Pediatr Infect Dis J 1992;11:1043-6.

231. Kubin R. Safety and efficacy of ciprofloxacin in paediatric patients - review. Infection 1993;21:413-21.

232. Martell M, de Ben S, Weinberger M, Beltrami G. Growth and development in preterm infants receiving fluoroquinolones. J Perinat Med 1996;24:287-91.

233. Shiba K, Sakai O, Shimada J, Okazaki O, Aoki H, Hakusui H. Effects of antacids, ferrous sulfate, and ranitidine on absorption of DR-3355 in humans. Antimicrob Agents Chemother 1992;36:2270-4.

234. Shiba K, Sakamoto M, Nakazawa Y, Sakai O. Effects of antacid on absorption and excretion of new quinolones. Drugs 1995;49(Suppl 2):360-1. (Abst)

235. Teng R, Dogolo LC, Willavize SA, Friedman HL, Vincent J. Effect of Maalox and omeprazole on the bioavailability of trovafloxacin. J Antimicrob Chemother 1997;39(Suppl B):93-7.

236. Stab HH, Boettcher M, Horstmann R. Study to evaluate the interaction between BAY 12-8039 and antacids. Twentieth International Congress of Chemotherapy. June 29 to July 3, 1997. Sydney: Bayer AG, 1997:13. (Abst)

237. Mignot A, Douin MJ, Millerioux L, et al. Effect of aluminum hydroxide antacid on the pharmacokinetics of the new quinolone RP-64206. Thirtieth Interscience Conference on Antimicrobial Agents and Chemotherapy. Atlanta, October 21 to 24, 1990. (Abst 1250)

238. Kanemitsu K, Hori S, Yanagawa A, Shimada J. Effect of ferrous sulfate on the absorption of sparfloxacin in healthy volunteers and rats. Drugs 1995;49(Suppl 2)352-6. (Abst)

239. Shiba K, Sakamoto M, Saito A, et al. Effect of ferrous sulfate, tea and milk on absorption of AM-1155, a 6-fluoro-8-methoxy quinolone in humans. Thirty-fifth Interscience Conference on
Antimicrobial Agents and Chemotherapy. San Francisco, September 17-20, 1995. (Abst A43)

240. Lee LJ, Hafkin B, Lee ID, Hoh J, Dix R. Effects of food and sucralfate on a single oral dose of 500 milligrams of levofloxacin in healthy subjects. Antimicrob Agents Chemother 1997;41:2196-200.

241. Matuschka PR, Vissing RS. Clinafloxacin-theophylline drug interaction. Ann Pharmacother 1995;29:378-80.

242. Niki Y, Hashiguchi K, Okimoto N, Soejima R. Quinolone antimicrobial agents and theophylline. Chest 1992;101:881. (Lett)

243. Efthymiopoulos C, Bramer SL, Maroli A, Blum B. Theophylline and warfarin interaction studies with grepafloxacin. Clin Pharmacokinet 1997;33(Suppl 1):39-46.

244. Stab HH, Kubitza D, Schwietert H, Wemer R. BAY 12-8039 does not interact with theophylline. Twentieth International Congress of Chemotherapy. June 29 to July 3, 1997. Sydney: Bayer AG, 1997:15. (Abst)

245. Gisclon LG, Curtin CR, Fowler CL, Williams RR, Hafkin B, Natarajan J. Absence of a pharmacokinetic interaction between intravenous theophylline and orally administered levofloxacin. J Clin Pharmacol 1997;37:744-50.

246. Takagi K, Yamaki K, Nadai M, Kuzuya T, Hasegawa T. Effect of a new quinolone, sparfloxacin, on the pharmacokinetics of theophylline in asthmatic patients. Antimicrob Agents Chemother 1991;35:1137-41.

247. Dickens GR, Wermeling D, Vincent J. Phase I pilot study of the effects of trovafloxacin (CP-99,219) on the pharmacokinetics of theophylline in healthy men. J Clin Pharmacol 1997;37:248-352.

248. Vincent J, Teng R, Dogolo LC, Willavize SA, Friedman HL. Effect of trovafloxacin, a new fluoroquinolone antibiotic, on the steady-state pharmacokinetics of theophylline in healthy volunteers. J Antimicrob Chemother 1997;39(Suppl B):81-6.

249. Springuel P. Drugs causing prolongation of QT interval and torsades de pointes. Can Med Assoc J 1998;158:103-4.

250. Liao S, Palmer M, Fowler CA, Nayak RK. Absence of an effect of levofloxacin on warfarin pharmacokinetics and anticoagulation in male volunteers. Thirty-fifth Interscience Conference on Antimicrobial Agents and Chemotherapy. San Francisco, September 17-20, 1995. (Abst A42)

251. Teng R, Apseloff G, Vincent J, Pelletier SM, Willavize SA, Friedman HL. Effect of trovafloxacin (CP-99,219) on the pharmacokinetics and pharmacodynamics of warfarin in healthy male subjects. In: Trovafloxacin: A Review of Publications and Congress Presentations. West Sussex: Cambridge Medical Publications, 1997:140-1. (Poster)

252. The choice of antibacterial drugs. Med Letter Drug Ther 1998;40:33-42.

253. Balfour JA, Faulds D. Oral ciprofloxacin: a pharmacoeconomic evaluation of its use in the treatment of serious infections. Pharmacoeconomics 1993;3:398-421.

254. Paladino JA, Sperry HE, Backes JM, et al. Clinical and economic evaluation of oral ciprofloxacin after an abbreviated course of intravenous antibiotics. Am J Med 1991;91:462-70.

255. Fliegelman RM, Mattingly PM, Dempsey CL, Sokalsi SJ. Economic impact of oral ciprofloxacin following standard intravenous therapy. Diagn Microb Infect Dis 1990;13:187-9.

256. Paladino JA. Pharmacoeconomic comparison of sequential IV/Oral ciprofloxacin versus ceftazidime in the treatment of nosocomial pneumonia. Can J Hosp Pharm 1995;48:276-83.

257. Canadian Coordinating Office for Health Technology Assessment. Clinical and Economic Considerations in the Use of Fluoroquinolones. Ottawa: Canadian Coordinating Office for Health Technology Assessment, 1997. 


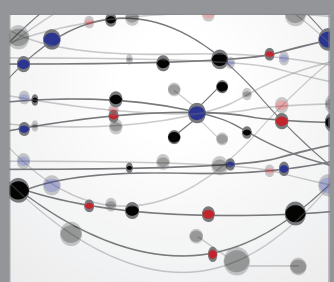

The Scientific World Journal
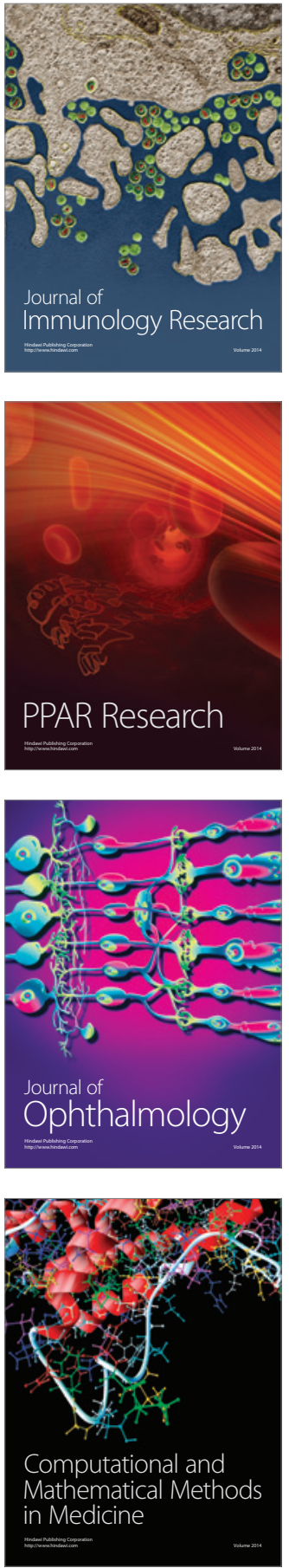

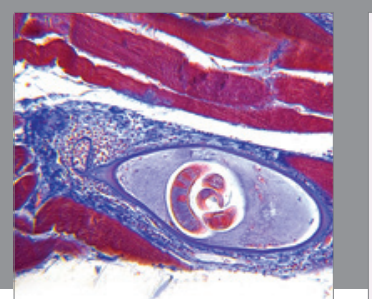

Gastroenterology Research and Practice

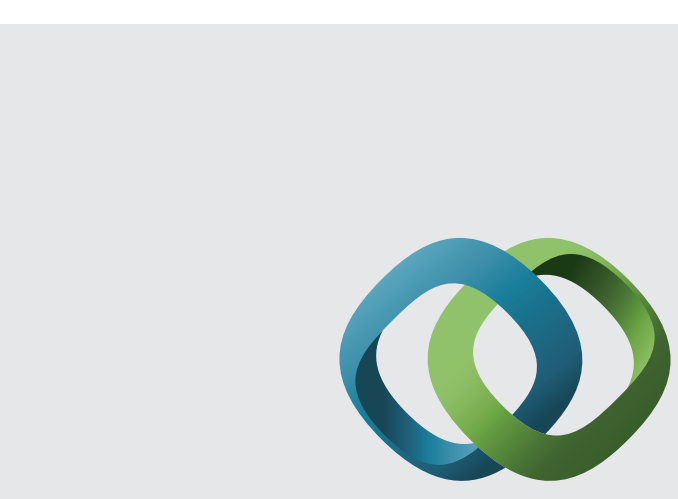

\section{Hindawi}

Submit your manuscripts at

http://www.hindawi.com
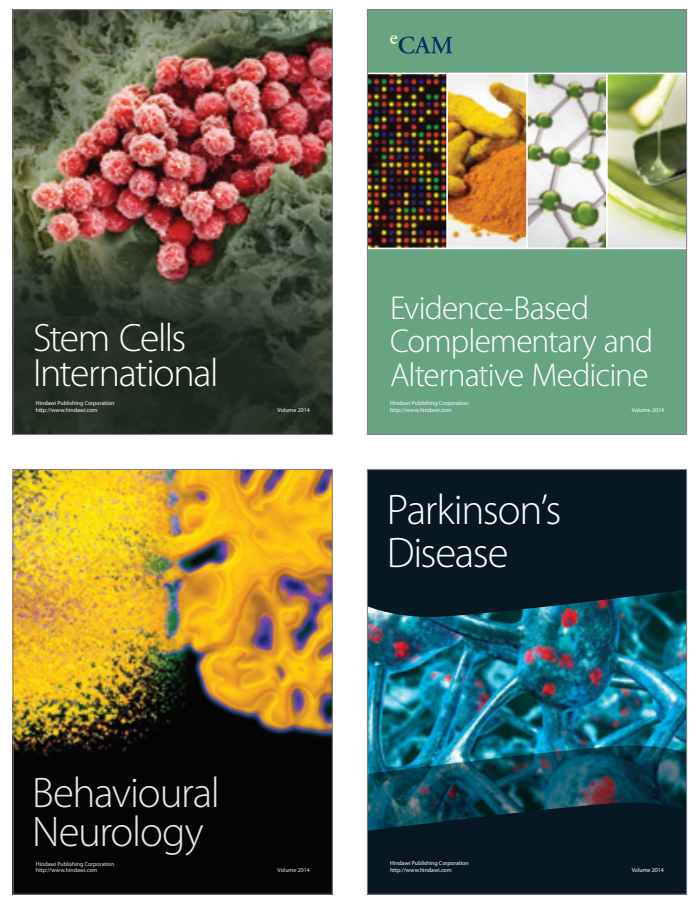
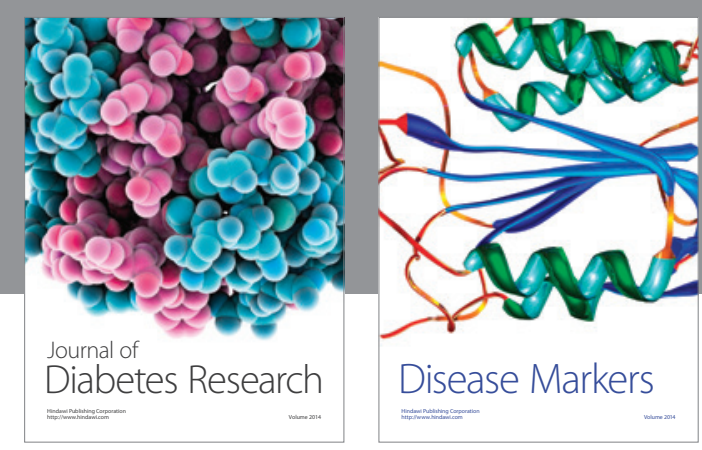

Disease Markers
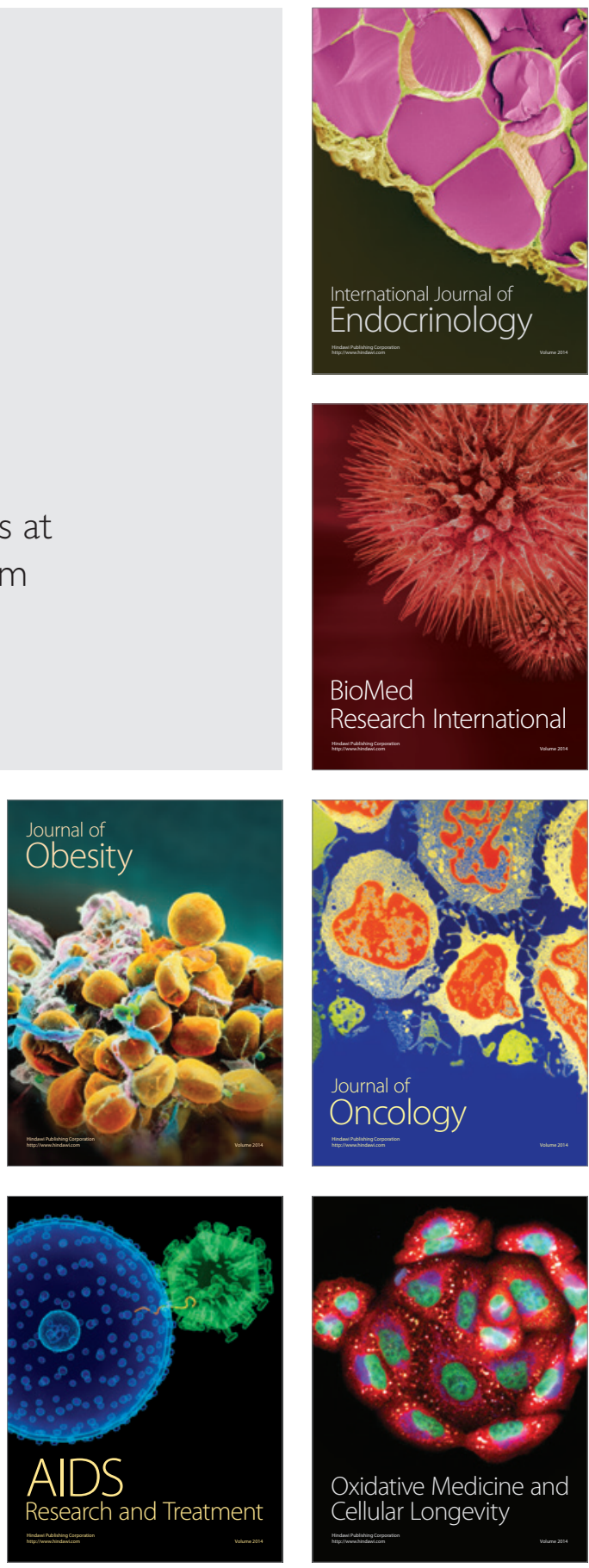